University of San Diego

Digital USD

Dissertations

Theses and Dissertations

2014-05-01

\title{
Comparing Factors of Bachelor's Degree Attainment for First and Continuing Generation Students
}

Holly Gilbertson Hoffman PhD

University of San Diego

Follow this and additional works at: https://digital.sandiego.edu/dissertations

Part of the Leadership Studies Commons

\section{Digital USD Citation}

Gilbertson Hoffman, Holly PhD, "Comparing Factors of Bachelor's Degree Attainment for First and Continuing Generation Students" (2014). Dissertations. 857.

https://digital.sandiego.edu/dissertations/857

This Dissertation: Open Access is brought to you for free and open access by the Theses and Dissertations at Digital USD. It has been accepted for inclusion in Dissertations by an authorized administrator of Digital USD. For more information, please contact digital@sandiego.edu. 

AND CONTINUING GENERATION STUDENTS

\author{
by
}

Holly Gilbertson Hoffman

A dissertation submitted in partial fulfillment of the requirements for the degree of

Doctor of Philosophy

May 2014

Dissertation Committee

Fred J. Galloway, Ed.D., Chair Christopher B. Newman, Ph.D., Member

Paula S. Krist, Ph.D., Member

University of San Diego 
(C) Copyright by Holly Gilbertson Hoffman

All Rights Reserved 2014 


\begin{abstract}
Colleges and universities have recently been under great pressure to increase institutional graduation rates, due to a surge in consumer demand for accountability and the use of graduation rates to determine effectiveness and funding. Many colleges may choose to achieve higher graduation rates by simply increasing selectivity. However, this strategy has the potential to exclude at-risk student populations, namely first generation students, who lack a family track record of college completion and have been shown to be less likely to graduate than continuing generation students. To allow for continued access for first generation students, institutions have the ability to design initiatives based on an extensive framework of salient factors identified in the literature; however, there is a critical need to identify which factors have the greatest influence on first generation degree attainment.
\end{abstract}

As such, this quantitative study examined how factors influencing student success vary for first and continuing generation students through an analysis of a nationally representative dataset from the 2004/2009 Beginning Postsecondary Students Longitudinal Study. Several logistic regression models were employed to identify differences in degree completion predictors for three groups of students: first generation students whose parents did not attend college, first generation students whose parents attended some college, and continuing generation students. Theoretical models of student persistence and attainment informed variable selection. Results revealed differences in the significant predictors of bachelor's degree completion for the three groups of students. For example, taking a rigorous high school curriculum predicted degree completion for both groups of first generation students, but not for continuing 
generation students. Consulting a college guide was a significant predictor only for students whose parents did not attend college. Having a sibling attend college first increased the likelihood of graduating for students whose parents did not attend college and continuing generation students. Taken together, these findings suggest predictors of degree completion vary for first and continuing generation students and indicate a student's level of knowledge about the college going experience plays a role in degree completion for first generation students. The findings support colleges and universities developing distinct student success initiatives for these groups of students. 


\section{ACKNOWLEDGEMENTS}

My dissertation was completed with generous moral and financial support from numerous individuals. Specifically, I would like to offer my gratitude to:

- My dissertation committee and academic mentors, Dr. Fred Galloway, Dr. Christopher Newman, and Dr. Paula Krist for providing advice, support, encouragement, and insights from their expertise that contributed significantly to this work.

- My former colleagues at the Caster Family Center for Nonprofit and Philanthropic Research, Dr. Laura Deitrick, Pat Libby, and Dr. Heather Carpenter, for providing me with opportunities to hone my research and analytical skills and abilities.

- My colleagues in the doctoral program, Dr. Taylor Peyton Roberts, Maureen Guarcello, and Jessica Luchesi, who served as a support system, sharing encouragement and advice as we wrote our dissertations together.

- My husband, Brett, for his continued love and support, and encouragement when I needed it most.

- My parents, Mary and Larry Gilbertson, who instilled in me the value of education, and my sisters, Lisa Donalson and Lindsay Hughey, who were a source of encouragement throughout this process.

- The School of Leadership and Education Sciences, for their financial support in funding my education and for providing me with a graduate research assistantship, an opportunity that allowed me to recognize my passion for higher education research. 


\section{TABLE OF CONTENTS}

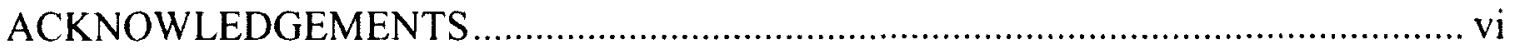

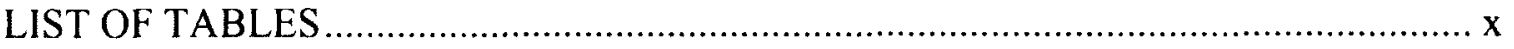

CHAPTER ONE: OVERVIEW OF THE STUDY …............................................ 1

Statement of the Problem ........................................................................... 9

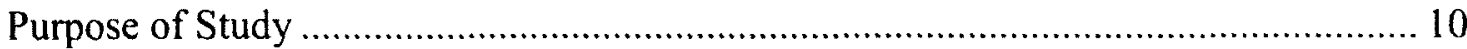

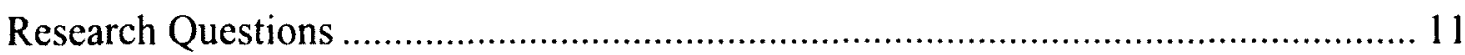

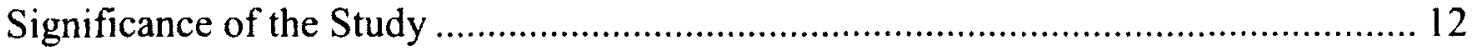

CHAPTER TWO: LITERATURE REVIEW ................................................... 13

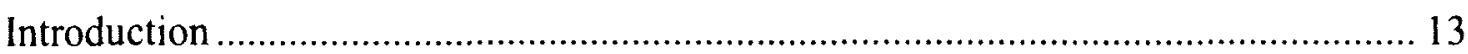

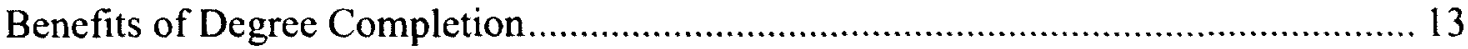

Theoretical Models of Student Persistence and Retention......................................... 19

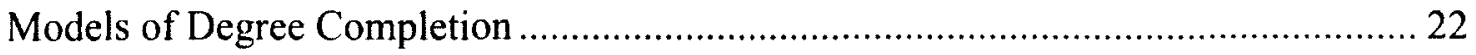

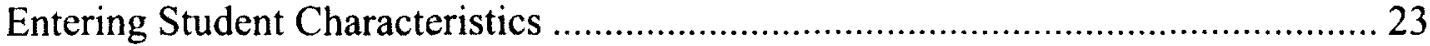

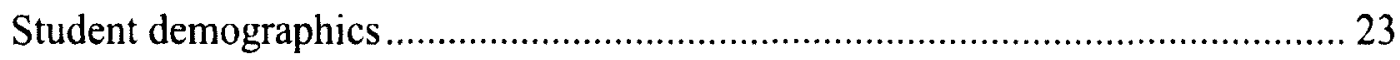

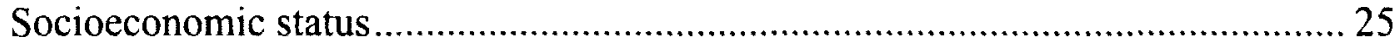

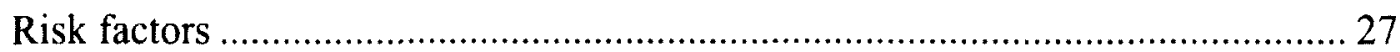

Pre-College Academic Performance and Preparation ....................................... 28

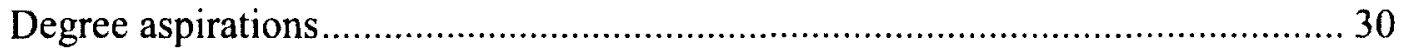

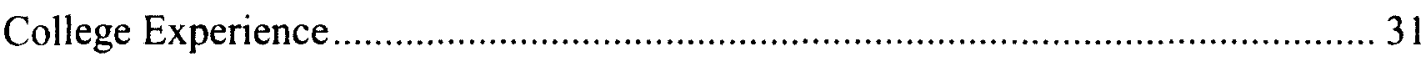

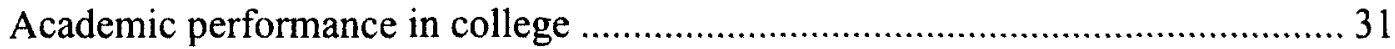

Credit accumulation and enrollment patterns ........................................... 32

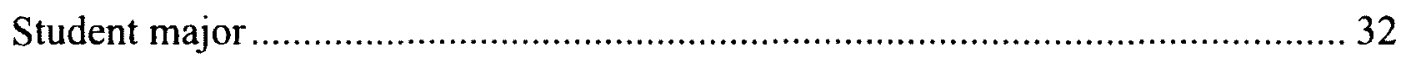

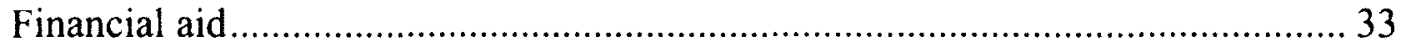

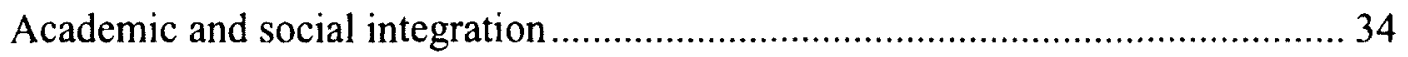

The Role of Cultural and Social Capital in First Generation Student Success ............ 37

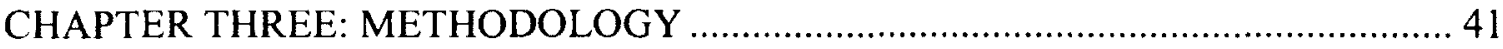

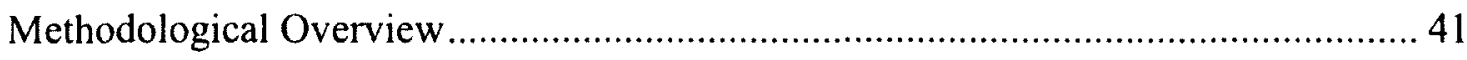

Overview of Data Source and Sample …............................................................. 41

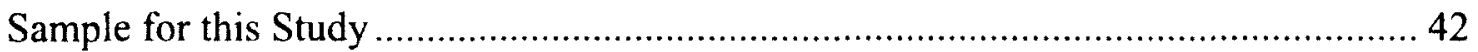

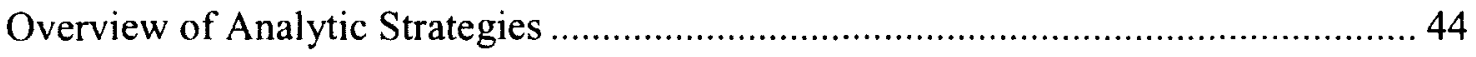




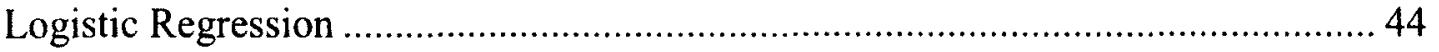

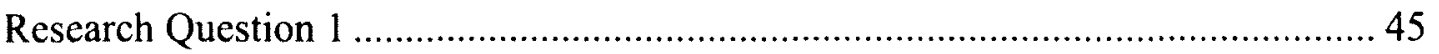

Dependent and independent variables ............................................................. 45

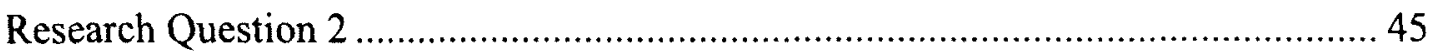

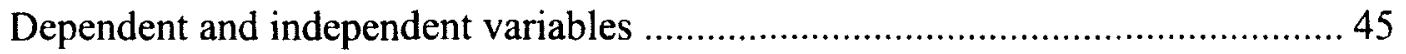

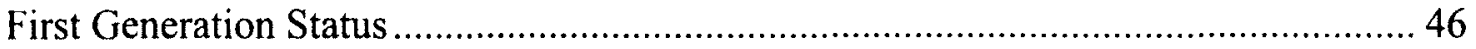

First Generation Student Definition ................................................................... 47

First Generation Status Independent Variables ....................................................... 48

First Generation Status Subgroups ................................................................. 49

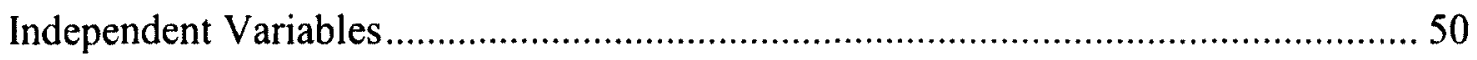

Student Demographics...................................................................................... 51

Pre-College Academic Performance and Preparation ............................................... 51

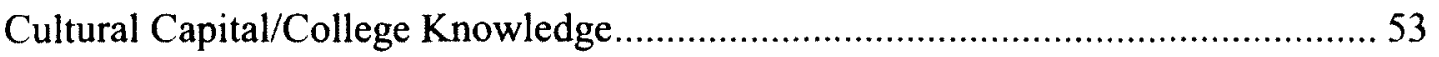

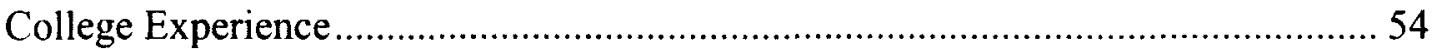

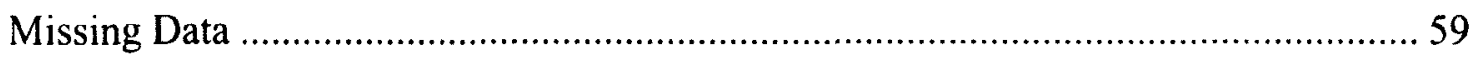

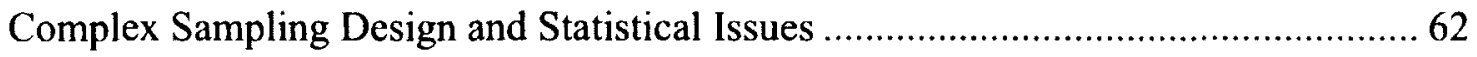

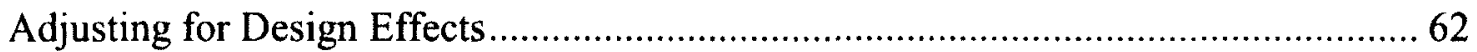

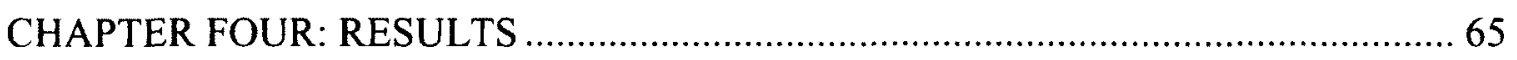

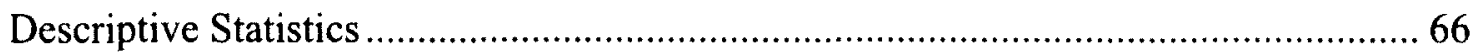

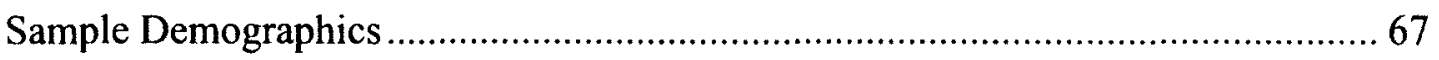

Differences in Predictors of Degree Completion ....................................................... 68

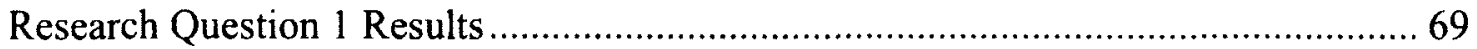

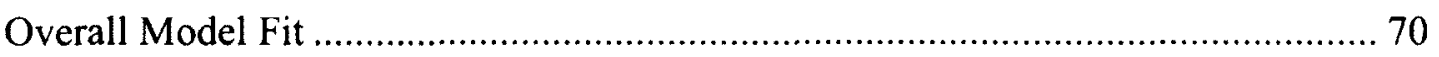

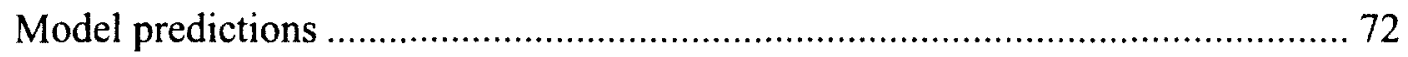

Major Findings for Research Question 1 ........................................................... 73

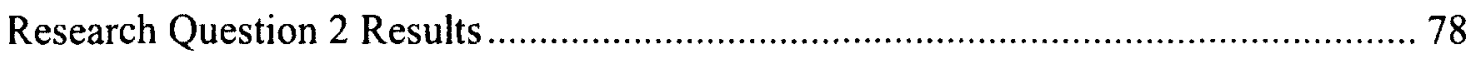

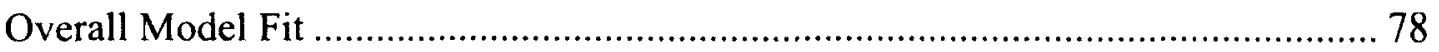

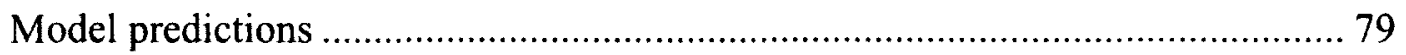

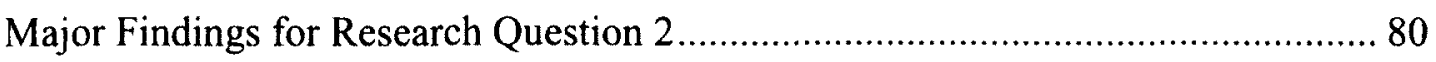

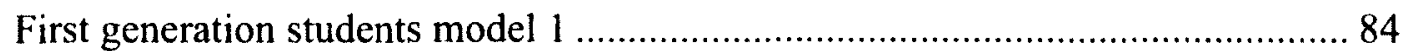

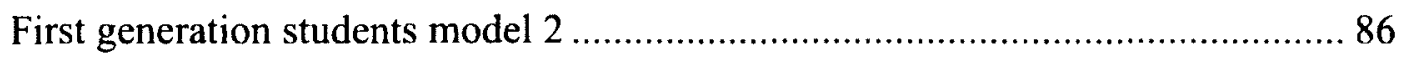




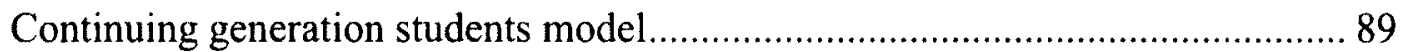

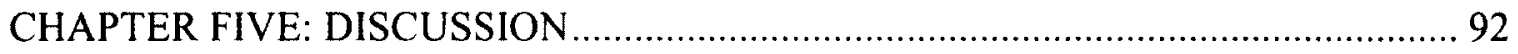

Overview of Purpose of the Study .......................................................................... 92

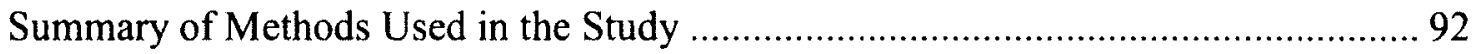

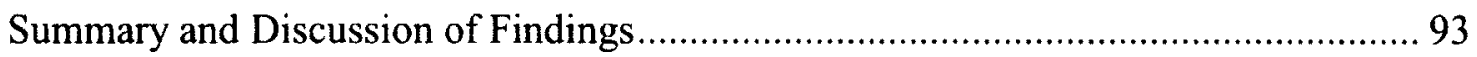

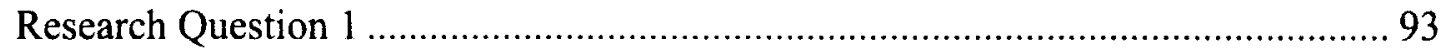

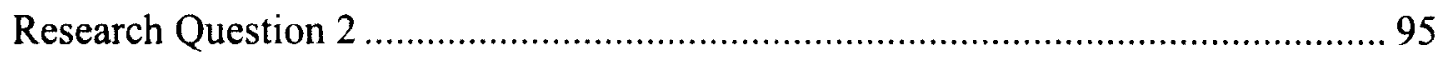

Comparison of Results to Previous Research ………................................................... 99

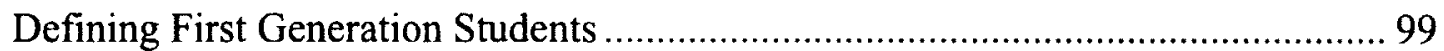

Predictors of Degree Completion for First and Continuing Generation Students ... 100 Implications for Colleges and Universities .......................................................... 105

First Generation Degree Completion Initiatives...................................................... 107

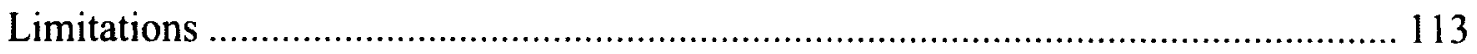

Implications for Future Research ................................................................ 115

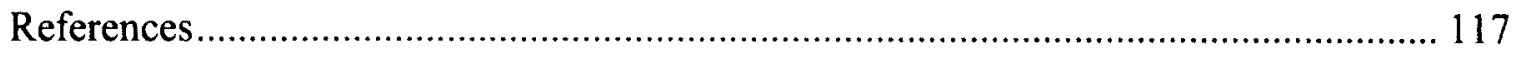




\section{LIST OF TABLES}

Table 1. First Institution Level by First Generation Status

Table 2. Highest Level of Parental Education

Table 3. Description of Independent Variables

Table 4. Missing Values by Independent Variable

Table 5. Selected Descriptive Statistics - Students Enrolled at a 4-Year Institution by 2006 (Percent).

Table 6. Selected Descriptive Statistics for Degree Completion Predictors (Means) ... 69

Table 7. Summary Prediction for Models for Research Question 1 72

Table 8. Summary of Model Results for Research Question 1 77

Table 9. Summary Prediction for Models by First Generation Status 80

Table 10. Summary of Model Results by First Generation Status

Table 11. Binomial Logistic Regression Results, Individual Predictors of Completing Bachelor's Degree in Six Years for First Generation Students-Parents Have No College Experience....

Table 12. Binomial Logistic Regression Results, Individual Predictors of Completing a Bachelor's Degree in Six Years for First Generation Students-Parents Have Some College Experience

Table 13. Binomial Logistic Regression Results, Individual Predictors of Completing a Bachelor's Degree in Six Years for Continuing Generation Students 91 


\section{CHAPTER ONE}

\section{OVERVIEW OF THE STUDY}

Expanding access to higher education for first generation students has been an important initiative undertaken by colleges and universities, federal and state governments, and other members of the higher education community over the past few decades. The federal TRIO programs, designed to increase postsecondary opportunities for disadvantaged and underrepresented students, have served more than one million students since their implementation in 1965 (Perna, Fenske, \& Swail, 2000). The Upward Bound program, in which two-thirds of the students served are from low-income families and are first-generation students, assists 59,000 high school students in preparing for college (p. 16). Though great effort has been expended to increase access for first generation students, research suggests first generation students are less likely than other students to complete a four-year degree. Ishitani (2003) and Chen and Carroll (2005) found first generation students are less likely to be enrolled after a year and less likely to earn a four-year degree than students whose parents had earned a degree. Warburton, Bugarin, and Nuñez (2001) reported only $55 \%$ of first generation students whose high school curriculum had a low academic rigor were continuously enrolled or had attained a bachelor's degree six years after entering college compared to $67 \%$ of their continuing generation counterparts.

The less than ideal degree completion rate of first generation students seen throughout the literature is alarming because the majority of benefits from higher education stem from earning a degree. While attending college has some benefits for students, including an increase in cognitive ability (Pascarella \& Terenzini, 2005), many 
researchers argue the majority of benefits associated with higher education come from actually completing a degree. For example, an analysis conducted by the National Center for Education Statistics concludes the economic returns for individuals from attending some college are negligible (Zucker \& Dawson, 2001). Similarly, Tinto (1993) indicates that attending college and leaving without a degree comes with negative monetary and occupational penalties due to the burdens of loans.

First generation students who attend college but do not graduate will not enjoy the numerous benefits associated with completing a degree at a college or university in the United States. There are both tangible and intangible benefits to students from earning a bachelor's degree including increased lifetime earnings and expanded career options (McMahon, 2009; Carnevale, Rose \& Cheah, 2011; Carnevale, Smith \& Strohl, 2010) and an improved quality of life that stems from having the ability to make informed health and lifestyle decisions (Bowen, 1997; Mortenson, 1999). Society benefits from the resulting economic growth (Paulsen, 2001) and increased civic participation (DesJardins, Ahlburg, \& McCall, 2002).

While research on how to improve first generation degree completion is critical to ensure first generation students are able to earn their degrees and enjoy the benefits associated with a college degree, there is another compelling reason for undertaking research in this area. First generation students are currently at risk of losing access to higher education due to the changing priorities of many colleges and universities. Though access is one of the widely accepted goals of higher education (Bowen, 1997), recent changes in legislation have pressured higher education institutions to shift their focus from providing access to a diverse population of students to finding strategies to 
increase institutional graduation rates. One of the most common strategies is to increase selectivity in the application process, thus excluding from admission students who belong to at-risk populations and have lower probabilities of graduating. The pressure to improve graduation rates has been driven by several factors including: 1) legislation which increased the visibility of institutional graduation rates, 2) stagnant national graduation rates, 3) a shift in public opinion regarding the value of a college education, and 4) the use of graduation rates to allocate funding.

Institutional graduation rates have been visible to the public since the Student Right to Know Act of 1990 and have been used by consumers to as a tool to compare institutions. Since then, many problems have arisen for institutions because the public availability of institutional graduation rates allows comparisons between institutions, whether or not the comparisons are valid. When using the graduation rate to decide which institution to attend, students will seek institutions with high graduation rates and avoid those with lower rates (Astin, 2005), although the literature suggests the variation between institutions' graduation rates cannot be attributed entirely to institutional policies and practices (Adelman, 2004; Astin \& Oseguera, 2005). Thus, institutions are under pressure to increase graduation rates using methods within their control, namely, limiting admission to only students with high probabilities of graduating.

Recently there has been renewed public interest in college completion and institutional graduation rates in light of several indicators suggesting the United States is not remaining competitive globally in terms of degree attainment (Russell, 2011). One particularly persuasive piece of evidence was a report conducted by the Organization for Economic Cooperation and Development that ranked the United States 12th of 36 
developed nations in the percentage of adults, age 25-34, holding at least an associate's degree (OECD, 2010). Although the ranking was partly influenced by trends in other countries, such as expansion of college attendance in Asia and Europe and the fact that other nations focus on one to two year credentials (De Vise, 2011) the unimpressive showing of the United States in college completion rates has led the public and policy makers to shift away from the traditional focus of increasing educational access and to set degree attainment as the new goal for today's colleges and universities (Russell, 2011).

Stagnant graduation rates reported by the National Center for Education Statistics (NCES) indicated a potential problem with the number of students graduating from college. In an analysis of data from the Beginning Postsecondary Study (BPS), $62.7 \%$ of students who began at a four-year college obtained a bachelor's degree in six years in 1996 (Berkner, He, \& Cataldi, 2002) and in 2003, 63.2\% of students obtained a bachelor's degree in six years (Radford, Berkner, Wheeless, \& Shepherd, 2010). Using the policy window opened by the public's renewed interest in degree completion, the Obama administration introduced the 2020 College Completion Goal, legislation with the goal of increasing the percentage of US adults, age $25-64$, holding degrees from $40 \%$ to $60 \%$ in 10 years (U.S. Department of Education, 2011). Though the legislation was primarily focused on community colleges, the completion goal sparked a series of national and regional college completion initiatives sponsored by the federal government, national higher education associations, and major foundations (Russell, 2011), further cementing degree attainment as the new primary objective for four-year institutions.

The renewed interest in graduation rates by policy makers and the public occurred at the same time as a rising consumer demand for accountability from colleges and 
universities. The call for accountability was fueled by concerns that tuition and fees are growing at a rate incompatible with the educational benefits and other outcomes institutions provide to students (Leveille, 2005). Because graduation rates have come to be viewed by the public and policy makers as measureable indicators of institutional performance, there has been a surge in the use of graduation rates to allocate funding (Adelman, 2004; Lam, 1999). Numerous states have accepted institutional graduation rates as a measure of effectiveness and have instituted policies to tie graduation rates to performance-based funding. The policies are designed to reward effective institutions, or those with high graduation rates, and punish those institutions deemed ineffective, or those with low graduation rates (Banta, Rudolph, Van Dyke, \& Fisher, 1996; Blose, 1999).

The call for greater accountability in higher education has put higher education institutions under great pressure to increase institutional graduation rates by any means possible. Many institutions are considering a particular strategy that would help them improve institutional graduation rates rapidly, increasing the selectivity of admissions. At the institutional level, the strategy of improving graduation rates by limiting admission to those applicants with a high probability of graduating can be seen as a rational response to satisfy the demands of the government and the public to demonstrate institutional effectiveness. However, this strategy has the potential to exclude at-risk students with traditionally low completion rates, such as first generation students, from higher education.

First generation students, who lack a family track record of college completion, have been identified as an at-risk student group in terms of graduating from college. 
Generally defined as students whose parents' highest level of education is a high school diploma or less, the literature indicates first generation students have lower persistence rates and do not perform as well as continuing generation students; or students whose parents have attended college. In an analysis of a cohort of students starting college in 1989, Nuñez and Cuccaro-Alamin (1998) found first generation students (44\%) were less likely than continuing generation students $(56 \%)$ to have attained a postsecondary degree or certificate five years after their initial enrollment. According to Chen and Carroll (2005), first generation students attending four-year institutions were less likely to earn a degree $(47 \%)$ than students whose parents had a college degree $(78 \%)$. Using data from the 1996 Beginning Postsecondary Student Study (BPS: 96/01), Engle and Tinto (2008) compared students who were first generation and low-income to students who were not classified as low-income and first generation. After six years, only $11 \%$ of first generation, low-income students had eamed bachelor's degrees compared to $55 \%$ of students who were not classified as low income and first generation (p.12). Though the study did not separate the effect on degree completion of first generation status from the effect of socioeconomic status, other studies indicate first generation students are less likely to be enrolled after a year (Ishitani, 2003) and less likely to earn a bachelor's degree (Chen \& Carroll, 2005), after controlling for other demographic factors including family income as well as factors related to pre-college academic preparation and postsecondary performance.

Rather than deny access to first generation students who have a lower probability of graduating from college, institutions can create institutional initiatives and polices tailored to first generation student needs in order to "help mitigate the differences 
between first generation and non-first generation students" and to "help colleges reach their goal of recruiting and retaining all students" (Tym, McMillion, Barone \& Webster, 2004, p. 1). Institutions have the ability to design targeted intervention efforts to improve first generation student success by identifying and understanding the factors assisting or hindering degree completion for today's first generation students.

Previous degree completion research has identified a framework of determinants of student success for students overall. For example, students from low SES quartiles are less likely to complete a bachelor's degree (Titus, 2006; Adelman, 2004) even after controlling for background characteristics (Choy, 2000; Bailey \& Dynarski, 2011). Students' pre-collegiate academic preparation and performance including high school GPA, SAT test scores, and high school curriculum are the strongest predictors of degree completion (Adelman, 2004; Astin \& Lee, 2003). Numerous studies indicate academic performance in college is a strong determinant of degree completion (Adelman, 2004; Ishitani, 2003; Titus, 2006), as is credit accumulation in the first year (Adelman, 1999; McCormick \& Carroll, 1999).

Though many predictors of college graduation have been identified by previous studies, research suggests first and continuing generation students "differ in notable ways" (Hahs-Vaughn, 2004); these include demographic characteristics, course-taking patterns, and choices related to college. Previous research conducted in 1998 and 2001 using data from the Beginning Postsecondary Students Longitudinal Study showed consistent demographic trends among the first generation student population: first generation students are more likely to be female, non-white, and of lower socioeconomic status, as well as more likely to be receiving financial aid (Nuñez \& Cuccaro-Alamin, 
1998). First generation students are also more likely than continuing generation students to be independent, to have dependents, to be enrolled part time, and to be working full time (Nuñez \& Cuccaro-Alamin, 1998; Warburton, Bugarin, \& Nuñez, 2001). In terms of choice of major, Chen and Carroll (2005) found first generation students are less likely than continuing generation students to declare a major when entering college and business was the most chosen major among first generation students who declared a major upon entry.

More importantly, several scholars suggest differences between first and continuing generation students are related to how the two groups of students experience college and what they value (Berger, 2000; Paulsen \& St. John, 2002). These types of differences could potentially impact educational outcomes such as persistence and graduation. For example, a study conducted by Terenzini and his colleagues (1996) found differences in the college experiences of first and continuing generation students had an impact on learning gains in the first year, particularly in reading comprehension.

If the college experiences of first generation students differ from continuing generation students, there is a need to investigate the possibility that the magnitude of impact of previously identified factors on degree completion varies for first and continuing generation students. There are a few existing studies, however, comparing first and continuing generation students in terms of how existing factors influence degree attainment. Hahs-Vaughn (2004) conducted a study using structural equation modeling and discovered variables related to the college experience had a stronger influence on educational outcomes including degree attainment than variables related to demographic traits and pre-college performance. In a comparison of determinants of first-year 
persistence for first and continuing generation students, Lohfink and Paulsen (2005) identified several differences between the groups of students. Specifically, the study indicated first generation persistence was positively influenced by academic integration, but the factor did not significantly predict continuing generation persistence (p. 421). Both of the above mentioned studies used data on cohorts of students who entered postsecondary education in the 1990 s. Since the 1990 s, the student population has experienced many changes. For example, there was a major shift in the demographics of the students who attend higher education institutions, including an increase in nontraditional students, such as part time students, adult students, and students transferring between institutions (Scott, Bailey, \& Kienzel, 2006). Therefore, to better understand the primary determinants of first generation student degree completion for the current student population, research conducted using data from a more recent cohort of students is necessary.

\section{Statement of the Problem}

Although universities, colleges, and numerous other members of the education community have worked to improve access to higher education for first generation students, the literature indicates this population of students is less likely to complete bachelor's degrees than continuing generation students (Nuñez \& Cuccaro-Alamin, 1998; Chen \& Carroll, 2005). As a result, many first generation students do not receive the numerous benefits attributed to degree completion. Additionally, the recent pressure colleges and universities face to increase graduation rates has the potential to limit access to higher education for first generation students. If institutions decide to improve graduation rates by limiting admission to only students who have a high probability of 
graduating, first generation students are at high risk of being excluded from higher education because they lack a family track record of college completion and have lower persistence and completion rates (Choy, 2002; Nuñez \& Cuccaro-Alamin 1998).

To continue to provide access to higher education to first generation students, institutions have the ability to implement initiatives designed to improve the success of these students. Tailoring recruitment and retention initiatives to the needs of first generation students requires an understanding of the characteristics, choices, and other factors influencing degree completion specifically for first generation students. Even though previous research has identified a framework of factors influencing degree completion, differences exist in how first generation students and continuing generation students experience college (Hahs-Vaughn, 2004). Thus, there has been the need to investigate the possibility the impact of previously identified factors on degree completion varies for first and continuing generation students. Finally, to inform success initiatives that will effectively meet the needs of today's first generation students, research conducted using a more recent cohort of students is needed to build on previous studies that used data on cohorts of students who enrolled in college in the 1990s.

\section{Purpose of Study}

The purpose of this quantitative study was to use secondary data analysis to develop and test models of degree completion, determining how the factors influencing student success vary for first generation students as compared to continuing generation students. Specifically, the study focused on two aspects of first generation student degree completion using a national, longitudinal dataset of 16,700 students, representing a recent cohort of students who entered college in 2003. First, the study examined the 
relationship between first generation status and degree completion after controlling for student background characteristics and college experience variables identified as salient predictors in existing degree completion models. Second, the study tested whether the predictors of degree completion vary for three student groups: first generation students whose parents have no college experience, first generation students whose parents have some college experience, and continuing generation students. The study helps inform institutional initiatives to improve first generation student degree attainment at four-year colleges and universities.

\section{Research Questions}

The study analyzed data from a national, longitudinal dataset of 16,700 students who entered college in 2003 to examine degree completion for first generation college students and answer the following research questions:

1) To what extent can degree completion in six years be predicted by 1) first generation status, 2) student demographics, 3) pre-college academic performance and preparation variables, 4) college knowledge/cultural capital variables, and 5) college experience variables?

2) Which demographic, pre-college academic performance and preparation, cultural capital/college knowledge, and college experience variables predict bachelor's degree completion in six years for first generation students whose parents have no college experience, first generation students whose parents have some college experience, and continuing generation students and how do these factors vary for the three student groups? 


\section{Significance of the Study}

The study has implications for those involved in efforts to increase degree attainment for first generation students and will inform the design of institutional initiatives to meet the needs of first generation students. The study's findings help to provide information about how pre-college academic preparation and college knowledge factors influence first generation student success for institutions to use when working with high school principals, guidance counselors, and teachers. The findings provide institutions with a better understanding about how aspects of the college experience assist or hinder first generation student degree completion as compared to continuing generation students. Greater understanding of how predictors of degree completion vary for first generation students whose parents have no college experience, first generation students whose parents have some college experience and continuing generation students will allow institutions to identify the areas of most need for first generation success initiatives so they can allocate resources accordingly. 


\section{CHAPTER TWO}

\section{LITERATURE REVIEW}

\section{Introduction}

Research on student persistence, retention, and degree completion has been conducted consistently for the past thirty years and has produced a vast array of theories, models, and factors to help explain why and predict whether a student persists at a university or college and graduates with a degree. Though extensive research has been done on this topic, it is important to continue conducting and refining research in this area to improve graduation rates for at-risk student populations like first generation students. The literature discussed in the beginning of this chapter highlights the impact holding a college degree has on individuals and society in order to demonstrate the need for research to increase the number of first generation students graduating with bachelor's degrees. The remainder of the chapter focuses on the theoretical underpinnings of degree attainment research with a discussion of the theoretical frameworks and empirical models that guided the creation of the degree completion model used in this study. An emphasis is placed on how factors of degree attainment identified by existing theories and models relate to first generation status. The section concludes with a summary of a theoretical framework based on social reproduction theory particularly suited to understanding first generation student success.

\section{Benefits of Degree Completion}

Increasing graduation rates for first generation students is important because holding a college degree has been linked to an improved quality of life for individuals, which then has been shown to have a positive impact on society as a whole. Some of the 
benefits for individuals from degree completion include increased lifetime earnings and expanded career options. A report by the Georgetown University Center on Education and the Workforce found the median lifetime earnings of a bachelor's degree holder in the United States are $\$ 2.3$ million as compared to the $\$ 1.3$ million for a high school diploma holder, suggesting individuals who earn bachelor's degrees will make on average one million dollars more over their lifetime than those with high school diplomas (Carnevale, Rose, \& Cheah, 2011). In an analysis of U.S. Census data on the earnings of college graduates from 1980-2007, McMahon (2009) came to a similar conclusion, estimating bachelor's degree completers will earn on average $\$ 1.1$ million more in their lifetime as compared to high school graduates. Average earnings for U.S. college graduates have increased by $48 \%$ in real terms from 1980 to 2007 while average earnings for those with a high school education or less have remained flat during the same period (p. 74).

Individuals with college degrees have access to a larger and more diverse set of career options. It is estimated that by $2018,63 \%$ of jobs in the United States will require postsecondary education (Carnevale, Smith \& Strohl, 2010). Using advertised job openings in 100 large metropolitan areas, a Brookings Institution report found there were on average 12 jobs available for every one job seeker with a bachelor's degree compared to 2.9 jobs for workers with a high school diploma. The report noted overall, $43 \%$ of jobs required a bachelor's degree (Rothwell, 2012). Almost all of the occupations in today's job market experiencing the fastest growth, including professional, management, business, and financial occupations, require two or four years of college education. Most of the occupations currently in decline, such as agriculture and manufacturing, employ 
those with a high school degree or less (McMahon, 2009, p. 77). Along with improving career options, a college education is associated with increased personal status, especially for first generation college students (Terenzini, Springer, Yaeger, Pascarella, \& Nora, 1996).

Even when the costs of higher education are considered along with the benefits, research indicates degree attainment benefits individuals. Baum and Ma (2007) provide evidence demonstrating the increased lifetime earnings of college graduates outweigh the costs. Their analysis of 2006 U.S. Census data reveals the typical college graduate who enrolled at age 18 has earned enough by age 33 to repay loans equal to the full tuition and fees at the average public four year institution plus interest and compensate for forgone earnings during college. On average, cumulative net earnings, calculated as earnings minus loan debt and forgone earnings during college, for people with bachelor's degrees exceed those of people with associate's degrees at age 36, after 14 years in the workforce (p. 11).

In fact, previous research understates the positive impact of higher education because many of the individual benefits associated with earning a college degree are intangible. Typically, studies estimating the returns on education include only the tangible benefits of higher education by calculating private rate of returns, or the discounted present value of the earnings differential (McMahon, 2009; Paulsen, 2001). Though the costs of attending college including net tuition and fees and foregone earnings are tangible and easy to calculate, assigning a monetary value to many benefits associated with higher education is difficult. In a 1999 research letter, Mortenson posits skills learned in college, such as critical thinking and increased access to a variety of 
perspectives, are linked to a vast collection of non-economic benefits often overlooked by policy makers. Bowen (1997) concurs, arguing college education affects decisionmaking processes in consumer choice, health, and family planning that generally improve quality of life. Additionally, a college education improves the "efficiency and frequency of investments in good health" (p. 377). Mortenson (1999) provides an exhaustive list of health and lifestyle decisions made at higher rates by college graduates; decisions resulting in improvements to many aspects of life from personal safety to life expectancy. Individuals with bachelor's degrees are more likely than people with less education to wear seatbelts, exercise, and play sports regularly, schedule regular dental visits, and buy vitamin supplements (p. 77).

More recent studies evidence similar trends in health and lifestyle choices and other factors that help improve the quality of life among college graduates. When controlling for income, De Walque (2004) found college graduates were less likely to smoke than individuals who completed some college, high school graduates, and individuals with less than a high school degree (p. 5). Similarly Perna (2005) indicates the percentage of individuals reporting being smokers decreases at higher levels of education. A 2004 report and a 2007 follow up report conducted for the College Board indicated poverty rates within all household types were lower for college graduates (Baum \& Payea, 2004; Baum \& Ma, 2007). Along with making healthier choices, college graduates report being in better health than individuals with less education. The 2002 National Center for Education Statistics (NCES) Condition of Education report uses perceptions of health as an indicator of health, noting as education increases, individuals 
are more likely to report being in "excellent" or "very good" health (Wirt, Choy, Gerald, Provasnik, Rooney, Watanabe, \& Tobin, 2002).

Increasing the number of individuals with college degrees helps the nation as a whole by reducing the burden on society in several ways. Many of the better health and lifestyle choices made at a higher rate by college graduates, including not smoking and exercising regularly, result in lower associated health costs (Baum \& Ma, 2004). Health care costs are reduced because people with some college or a degree are more likely to participate in preventive health care practices (Mortenson, 1999), and health insurance coverage increases with educational attainment (Perna, 2005) as $79 \%$ of high school diploma holders had health insurance compared to $92 \%$ of those with at least a bachelor's degree (p. 30). In addition, college education reduces the demand for social support programs. As the level of education increases, individuals are less likely to live in households participating in public assistance programs such as Medicaid and reduced school lunch and food stamp programs (Baum \& Ma, 2007, p. 20).

Along with decreasing costs to society, degree completion is associated with public economic and social benefits, stemming from some of the private benefits college graduates receive from earning a college degree. Higher incomes of college graduates lead to economic benefits including increased tax revenue, greater productivity and increased consumption (Clinedinst, 2004). In terms of public social benefits, college graduates are more likely to contribute positively to society through civic duties such as voting (Snyder, Tan, \& Hoffman, 2003) and community service activities including volunteering and donating blood (DesJardins, Alhburg \& McCall, 2002), although it is important to note individual characteristics play a role in the choice to engage in these 
activities (Baum \& Ma, 2007). Similarly, descriptive analyses have illustrated college graduates have greater civic involvement as measured by voting and volunteering (Perna, 2005). Additionally, lower crime rates are found in regions with high proportions of college graduates (Hill, Hoffman, \& Rex, 2005).

McMahon (2009) argues education indirectly leads to long-term societal impact by sustaining democratic society, preventing authoritarianism, and creating political stability because college graduation is linked to factors necessary for maintaining democracy and democratic institutions. According to a report published by the Carnegie Foundation, postsecondary students tend to become more open-minded, more cultured, more rational, more consistent, and less authoritarian (Rowley \& Hurtado, 2002). College graduates are more likely to have attitudes conducive to democracy such as a "less unquestioning acceptance of authority, a desire to participate in public service, and informed participation in the voting process" (p. 203) and are more likely to serve in government on city councils, library boards, school boards, and juries (p. 193).

Families of college graduates enjoy benefits linked to the level of parental education. For example, children of college-educated parents are more likely to have higher cognitive development, graduate from high school, and attend college (Dawson, 1991). Additionally, children of college-educated parents are more likely to make behavior and lifestyle choices that generally lead to a better quality of life. For example, daughters of college-educated mothers are less likely to become unmarried teen parents (An, Haveman, \& Wolfe, 1993) and children of college-educated individuals tend to have higher levels of school readiness because they exhibit higher cognitive skills and engage in more extracurricular activities (Baum \& Ma, 2007). 


\section{Theoretical Models of Student Persistence and Retention}

The theoretical models of student persistence and degree completion used prevalently today in degree attainment studies were developed by scholars and researchers in the 1970's and have been consistently used since. These models stem from multiple disciplines, including economics, psychology, sociology, and organizational behavior. Each theoretical model incorporates one or more theories, in many cases from multiple fields, in an attempt to explain variations in educational outcomes including student persistence and degree attainment. Four prominent theoretical models will be discussed here and include the interactionist perspective originating in Spady's (1970) work and further developed by Tinto (1975, 1993), Astin's (1975) model of student involvement, Bean's (1979) model of student attrition, and Nora and Cabrera's (1996) student adjustment model.

Building upon existing models relating student attrition to family and academicrelated student characteristics, Spady (1970) used the concept of social integration found within Durkheim's (1951) theory of suicide to combine categories of salient variables into a single multidisciplinary framework and to allow the factors to be analyzed together in one model. Focusing on the intersection between student characteristics and the university environment, Spady (1971) describes a multistage process of interaction between the student and the university. The process begins with the student acting upon unique interests, goals, values, and previous experiences to adjust to the new environment and ends with the student succeeding at or failing to integrate fully in the academic and social systems of the university. Satisfaction derived from the student's successful 
academic and social integration relates directly to the student's commitment to the institution (p. 39).

Tinto (1975) built upon Spady's (1970) framework to articulate a theoretical model of student departure that explains processes of interaction between students and institutions leading over time to either persistence or dropout. Ideas central to Tinto's model are the separation of the processes of academic and social integration and the importance of distinguishing between processes leading to different types of dropout behavior such as academic failure or voluntary dropout (p. 90). Consistent with Spady's (1971) work, Tinto draws from Durkheim's (1951) theory of suicide, likening voluntary dropout from college to suicide, and posits a student's level of commitment to a college is positively associated with the student's level of integration with the other members and the values of the college community (p. 91). Drawing from economics, Tinto relates institutional and degree completion commitments to a cost-benefit analysis in which the student is considering whether an alternative investment of their time and resources in the form of transferring or dropping out of college will have benefits outweighing the costs (p. 97). Stressing the importance of both individual and institutional characteristics in explaining the processes of interaction leading to persistence or dropout, Tinto's model includes as predictors student background characteristics, pre-college attributes, and educational aspirations or goals as well as institutional commitment, or the tendency of an individual to commit to institutions with particular characteristics. Ultimately, Tinto's model asserts the more academically and socially integrated a student is at an institution, the more likely the student is to complete his or her degree at the institution (p. 96). 
Astin's (1975) longitudinal study of college dropouts identified several factors positively related to persistence including living on campus, participating in campus organizations such as sororities, fraternities, sports, and faculty-led research, and working part-time on campus. In a later study, Astin (1984) identified student involvement as a critical element in student persistence, after recognizing the elements found to be related to persistence in his previous study had a common thread. He noted each characteristic or activity positively related to persistence increases the level of involvement of the students. Conversely, factors from his previous study that were negatively associated with persistence, including working full-time off campus and family responsibilities were similar in that each results in a decreased level of student involvement (p. 524).

Involvement, as defined by Astin (1984), is measured in terms of the amount of time and energy students spend on activities related to the college experience, both academic and social, including but not limited to, studying, interacting with members of the college community, and participating in campus organizations.

Bean (1979) developed his model of student attrition by drawing factors from previous research on student attrition as well as viewing dropping out through the lens of organizational turnover, specifically a model of turnover in work organizations developed by Price (1977). Similar to employee turnover, whether a student persists or drops out depends on the level of organizational (institutional) commitment of which satisfaction is an intermediary outcome. Student satisfaction is derived from how students perceive institutional aspects the student encounters during interactions with the institution, interactions that are influenced by a student's background characteristics (Bean, 1979). Bean's (1990) updated student attrition model incorporates student intentions to leave or 
stay as a predictor of persistence as well as academic and social integration variables similar to those in Tinto's $(1975,1993)$ models. In a model of student attrition for nontraditional students, Bean and Metzner (1985) add factors external to the institution that include family and work responsibilities and financial considerations.

Nora and Cabrera (1996) constructed a model of persistence based on the relationships between student characteristics, academic and social integration, goal and institutional commitment, and persistence proposed in Tinto's $(1975,1993)$ model of student integration and Bean's (1979) model of student attrition in order to examine the role of perceptions of discrimination on both persistence decisions and other elements in the model including educational aspirations, social integration, and institutional commitment. Nora and Cabrera (1996) propose a relationship between a student's academic and social experiences and commitment that is unique from previous models. Their student adjustment model suggests if academic and social experiences assist in a student's development, there will be an increase in the student's commitment to completing a degree and to the institution. Distinguishing the student adjustment model from previous models are its incorporation of parental encouragement as a predictor of pre-college academic ability and persistence decisions (p. 123) and its assertion that perceptions of discrimination will impact a student's adjustment to college and persistence decisions (p.139).

\section{Models of Degree Completion}

Building upon the theoretical frameworks outlined in the previous section, scholars have developed and empirically tested models of degree completion, identifying several categories of factors influencing student success. For example, Astin and 
Oseguera (2005), using the degree completion information from 56,818 students from 262 institutions, created a formula that included over 50 variables identified as significant predictors in their study to calculate an institution's expected graduation rate. Previous studies, that tracked full cohorts of freshmen from college entrance to graduation, suggest the attainment of a college degree is influenced by various aspects of students' experiences throughout the process of entering and attending college. At the beginning of the process, entering student characteristics play an important role in a student's success (Tinto 1975, 1993; Adelman, 1999), as do the decisions and experiences that occur during the transition period between high school and colleges, namely student intentions and degree aspirations (Cabrera, Burkum, \& La Nasa, 2005). Aspects of the college experience such as levels of academic and social integration, enrollment patterns, credit accumulation, and financial aid (Adelman, 1999; Astin \& Osguera, 2005) have been identified as salient predictors of degree attainment.

\section{Entering Student Characteristics}

The entering student characteristics influencing degree completion most prevalent in previous research are student demographics, socio-economic status, pre-collegiate academic preparation and performance, and risk factors.

Student demographics. Research studies on the influence of student demographic on degree completion including gender and race/ethnicity have produced mixed results. Studies have shown that on average, women have a higher rate of degree completion than men. The average 2004 six year graduation rate for women was $60 \%$ and for men 54\% (Horn, 2006). According to Bailey and Dynarski (2011), whose study 
made use of U.S. Census data, for every birth cohort born after 1965, the percentage of women who graduated college by the age of 25 is higher than the percentage for men.

Gender and race were significant predictors of degree completion in Astin and Oseguera's 2005 study in which students were more likely to complete a degree if they are Jewish, female, or white. Instead of using gender and ethnicity as variables in a model, Pascarella's 1985 study, using data from 5,577 students enrolled in 352 institutions, looked at racial differences within variables identified as predictors of degree completion. Several differences among subgroups emerged from the analysis including: the number of institutions attended and institution size had significantly stronger negative associations with degree completion for black men than they did for white men and institutional commitment/satisfaction had a greater positive association with degree completion for men than for women.

In several other studies, student demographics were not found to be significant predictors of degree completion. Background variables including race/ethnicity and gender did not have a relationship to the probability of degree completion in a 2010 dissertation study conducted by Lee using the National Education Longitudinal Survey of 1988. After controlling for other factors, DesJardins, Kim, and Rzonca (2002) indicated there was no significant difference in the graduation rates of first year persisters (students who complete one year at the institution) by gender or race/ethnicity, but posit a potential interaction effect between gender and academic major may serve as an explanation. Adelman (2004) emphasized that race is not a significant predictor of degree completion in his study of a national cohort of students from the time they were in the 10th grade in 1980 until roughly age 30 in 1993: "No matter how many times (and in different 
formulations) we try to introduce race as a variable, it does not meet the most generous of threshold criteria for statistical significance" (p. 3).

Discrepancies in research findings on the influence of gender and race/ethnicity on degree completion may be due to differences in the combination of student characteristic variables chosen in each study and the result of shared effects of related variables. Lee (2010) argues studies have produced conflicting findings because many did not derive variables specifically from a theoretical model of attrition or retention. Desjardins, Alburg, and McCall (2006) posit effects attributed to student demographics are shared by other correlated factors. In their study of 12,648 first-time freshman who entered the University of Minnesota-Twin Cities in the fall terms of 1984, 1986, and 1991, student outcomes attributed to race were actually the result of differences in family income, age at entry, and high school performance.

Socioeconomic status. While research on the influence of gender and race/ethnicity on degree completion is inconclusive, socioeconomic status (SES) is consistently associated with degree completion. There is evidence to indicate students from low socioeconomic status are less likely to complete a bachelor's degree (Titus, 2006). Adelman (2004) showed SES has predictive power in his study's degree completion model, although the contribution SES provides is modest. After controlling for student background characteristics, a 2000 National Center for Education Statistics study indicated low-income students have lower persistence rates than students at higher income levels (Choy, 2000). A study conducted by Bailey and Dynarski (2011) analyzing data from two cohorts of students, one with students graduating from high school between 1979 through 1982 and the other with students graduating between 1997 
through 2000 , examined the relationship between family income and degree completion by dividing students into four income quartiles. For both cohorts, those in the top income quartile were more than twice as likely to graduate as those in the bottom quartile (p. 5).

In a study on a cohort of high school sophomores in 1980 who were tracked in the High School and Beyond Survey, Cabrera, Burkum, and La Nasa (2005) produced similar results, finding a moderate positive association between student socioeconomic background and the likelihood of earning a degree. An overall analysis of degree completion among the cohort revealed two trends regarding the variation occurring in the degree completion rates of students in different SES quartiles. First, the gap in degree completion rates across SES quartiles substantially increased the higher the quartile; and second, the students in the highest quartile were $44 \%$ more likely to earn a college degree than students in the lowest quartile.

Cabrera, Burkum, and La Nasa (2005) attribute the effect of socioeconomic status on degree completion to whether or not students have access to a pathway identified in their study as the most likely to lead to a degree. Students following the pathway, associated with a $78 \%$ chance of graduating within 11 years, are able to acquire a high level of academic resources in high school and enter at a 4-year institution upon high school completion. The study's analysis indicated this pathway was accessible to high socioeconomic status (SES) students, but was not equally available to students at the lowest SES level. Instead, students with a low SES status followed a pathway defined by moderate academic resources and first enrollment in a 2 -year institution. Similarly, in Lee's 2010 study, a delayed entrance to college was negatively associated with degree 
completion, and students from the lowest SES quintile were more likely to delay their college enrollment than students at other levels of SES.

In terms of socioeconomic background, first generation students are more likely than continuing generation students to come from low-income families. In an analysis of data from the 1988 National Education Longitudinal Study (NELS:88) conducted by Horn and Nuñez (2000), 51\% of students whose parents' highest level of education was a high school diploma or less had a family income in the lowest quartile compared to $29 \%$ of students whose parents had some college experience, and $8 \%$ of students whose parents highest level of education was a college degree. Similarly, in an analysis of data collected from 4000 students entering postsecondary education in 1992 in the National Study of Student Learning, the mean family income for first generation students was significantly lower than the mean family income for continuing generation students (Terenzini et al., 1996).

Risk factors. Several demographic factors negatively related to student persistence in college have been identified in the literature. A risk index comprised of seven factors was developed in a National Center for Education Statistics report analyzing data on undergraduates enrolled in 1992-1993 and was negatively associated with one year persistence (Horn \& Premo, 1995). The risk index includes the following factors: part-time enrollment, being financially independent, delaying postsecondary enrollment, having dependents, single parenthood, working full time while enrolled, and not receiving a regular high school diploma (p. 18). Berkner, Cuccaro-Alamin, McCormick, and Bobbitt (1996) applied the risk index in their analysis, finding a negative relationship between the number of risk factors a student has and completing a 
degree or being enrolled five years after beginning postsecondary education. The negative relationship between having dependents and persistence is corroborated by Nora, Cabrera, Hagedorn, and Pascarella (1996) who suggest family responsibilities compete with academic responsibilities, and Adelman (1999) who found students who have children while attending college are less likely to complete a college degree. In a study conducted by Cabrera, La Nasa, and Burkum (2001), having dependents while in college lowers the odds of degree completion by $22 \%$. Lee's 2010 study indicates students who have dependents to take care of during their time in college were more than two times less likely to graduate.

First generation students are more likely to have the risk factors associated with not completing a degree. According to Nuñez and Cuccaro-Alamin (1998) first generation students are more likely to have dependents and attend college part-time while Berkner and Chavez (1997) indicate that student plans to attend college directly after high school are related to parental education, with only approximately $68 \%$ of first generation high school students planning to attend postsecondary education immediately after high school as compared to $91 \%$ of continuing generation students (p. 17). First generation students tend to work more hours per week than continuing generation students whose parents had a bachelor's degree or above (Pascarella, Wolniak, Pierson, \& Terenzini, 2003)

\section{Pre-College Academic Performance and Preparation}

Not surprisingly, measures representing students' pre-collegiate academic preparation and performance are the strongest predictors of degree completion (Adelman, 2004; Astin \& Lee, 2005). The most common variables included in studies are high 
school GPA, SAT test scores, and high school curriculum. While some studies test for the individual effects of each variable, Adelman (2004) created an "academic resources" composite comprised of academic content and student performance in high school that takes into account the rigor and quality of the curriculum. The "academic resources" construct along with continuous enrollment in college, held the most explanatory power in Adelman's model.

Astin and Oseguera (2005) included high school curriculum variables in their degree completion model, focusing on the importance of student course-taking habits in high school. Positive academic predictors include completion of foreign language and physical science courses in high school. Warburton, Bugarin, and Nuñez (2001) similarly indicate taking specific courses in high school has a significant effect on degree completion, finding $87 \%$ of students who complete four years of math, science, and English in high school graduate from college compared with a $62 \%$ persistence rate among those who do not complete those courses. While the "academic resources" construct from Adelman's (2004) study includes the effect of many aspects of high school curriculum, in an earlier study from 1999, Adelman stresses the importance of math curriculum because the study's analysis indicates the completion of high level math courses in high school as the single best predictor of performing well academically in college.

Regarding pre-college academic preparation and performance, first generation students tend to be less academically prepared than continuing generation students in terms of initial critical thinking skills (Terenzini et al., 1996) and they have lower SAT scores and high school grade point averages (Riehl, 1994). The results of an analysis 
conducted Cabrera, La Nasa \& Burkum (2001), indicated $66 \%$ of students in the highest socio-economic status quartile were highly prepared academically for college while only $23 \%$ of lowest-SES students were highly prepared academically and first generation students are more likely to come from low-income families (Horn \& Nuñez, 2000). While taking particular courses in high school is associated with completing a degree, according to Warburton, Bugarin, and Nuñez (2001), first generation students are less likely to take calculus and to take a rigorous high school curriculum.

Degree aspirations. Degree aspirations in high school are related to degree completion because research indicates students who aspire to earn a four-year degree are more likely to participate in other activities positively associated with degree completion including taking a rigorous high school course curriculum, graduating from high school and applying to and enrolling in college (Cabrera \& La Nasa, 2001). Astin (1975) found students with educational goals of a doctorate or professional degree as most likely to persist in college. In a more recent study conducted by Cabrera, Burkum, and La Nasa (2005) that made use of data on a 1980 cohort of high school sophomores, students who aspired to complete a degree while in high school were $23 \%$ more likely to complete a degree than those who did not. There is evidence to suggest degree aspirations are related to parental education. For example, Terenzini and colleagues (1996) found first generation students in a sample of 4,000 students who entered college in 1992 had a significantly lower mean as compared to continuing generation students on a survey item asking about the highest degree they sought in their lifetime. 


\section{College Experience}

Aspects of a student's experiences while attending college including levels of academic and social integration, enrollment patterns, credit accumulation, and financial aid (Adelman, 1999; Astin \& Osguera, 2005) have been identified as salient predictors of degree attainment.

Academic performance in college. Numerous studies indicate academic performance in college is a strong determinant of degree completion (Adelman, 2004; Ishitani, 2003; Titus, 2006). Based on the positive, significant relationships between credit by exam, the number of credits earned in the first year, and a student's GPA in the first year of college and graduation, DesJardins, Alburg, and McCall (2006) suggest performance in college, as measured by student grades and credit accumulation, is a powerful indicator towards degree completion.

The relationship between college GPA and degree completion has been illustrated in numerous studies. Adelman (1999) demonstrated the importance of college GPA as a predictor of degree completion; finding students with a first-year GPA in the top $40 \%$ of their cohort are more likely to complete a degree. Corroboration for this claim is evidenced in the studies of both Herzog (2005) who found the first-year GPA of students initially enrolling in four-year universities predicted second-year persistence and Cabrera, Burkum, and La Nasa (2005) who indicated improvement in college GPA increased the probability of student graduation. In a study conducted by Desjardins, Kim, and Rzonca (2002) every one-grade increase in college GPA more than double a student's odds of a timely graduation which is defined as completing a degree in four years or less. 
Desjardins, Kim, and Rzonca (2002) suggest including college GPA in a degree completion model lessens the effect of pre-collegiate academic preparation and performance factors on degree completion after finding that upon including college GPA in their model, the power of high school academic resources as a predictor was lessened. However, this finding does not diminish the importance of pre-collegiate academic preparation because students who have stronger academic characteristics entering college are likely to perform well in college. The authors suggest pre-college preparation is important because it influences college GPA, which is a strong predictor of degree completion.

Credit accumulation and enrollment patterns. Previous research suggests the number of college credits completed in the first year is positively related to degree completion. Adelman's (1999) analysis of student enrollment indicated earning fewer than 20 units in the first year of enrollment has a negative relationship to degree completion. Another study demonstrated that among students beginning their enrollment in a 4-year institution, only $45 \%$ of students with fewer than 20 units in the first year completed a degree, while $91 \%$ of students with 30 credits completed a degree (McCormick \& Carroll, 1999).

Student major. Several research studies have included student major as a variable in their degree completion model based on the assumption that variation in degree completion between majors exist perhaps because majors have different graduation requirements, standards, and criteria for success (Kolb, 1981). However, previous research has produced conflicting findings on the role of major choice on degree completion. Kroc, Howard, Hull and Woodard (1997) conducted a study using data on 
204,000 freshmen entering 38 public, land grant, and Research I universities in 1988 and 1990 , finding graduation rates varied more by university than by program and students initially undecided about their major were no less likely to graduate than other students. In contrast, Desjardins, Kim, and Rzonca (2002) showed, among students who have successfully completed their freshman year, students who declared business, engineering, and health majors have odds of graduating that are much higher than students declaring social science majors. In posing an explanation for the conflicting findings on the influence of major on degree completion, Pascarella and Terenzini (1991) suggest it is possible the effect of major on degree completion may be complex. Not unlike student demographic variables, the effects attributed to major may be shared with related variables. In terms of major selection, previous research has found first generation students are less likely to take humanities and fine arts courses (Terenzini, et al., 1996) and more likely to major in business or health science than continuing generation students (Chen \& Carroll, 2005). Though conducted only in the limited scope of single institution studies, recent research indicates there is evidence to support a somewhat unexpected positive relationship between changing majors and degree completion (Murphy, 2000; Foraker, 2012).

Financial aid. Financial aid has primarily been studied in the context of student persistence, though a recent dissertation study included variables representing various types of financial aid and found need-based grant aid is associated with degree completion for low-income students and institutional grant aid impacts degree completion for students in the lower-middle and upper-middle income quartiles (Franke, 2012). DesJardins, Kim, and Rzonca (2002) posit the factors influencing student persistence 
relate to degree completion because persistence is a precursor to graduation. When student persistence is viewed through the lens of economics, successful persistence in college can be seen as the outcome of economic decisions. Financial aid factors into the decision as students engage in a cost/benefit analysis weighing the social and economic benefits of attending college and earning a degree and educational costs with the benefits and costs of alternative activities such as working full-time (Moore \& Shulock, 2009).

Overall, the literature suggests a positive relationship between financial aid and student persistence, though the effect of financial aid varies depending on the point where students are in their college career. In one study, students were more likely to persist between the second and third years if they received financial aid (Fenske, Porter, \& DuBrock, 1999) while in another study, receiving financial aid had the greatest effect in the third year (Ishitani \& DesJardins, 2002). Financial aid has a positive relationship with student persistence for at-risk populations, including first generation college students (Ishitani, 2006) and cohorts of low-income, minority, and female science, engineering, or math majors (Fenske, Porter, \& DuBrock, 1999). In contrast, using data from the Beginning Post-Secondary Student Surveys of 1995-1996 and 2000-2001, Kim (2007) found higher student loan debt was negatively associated with degree completion for low-income students after controlling for individual and institutional characteristics. In Adelman's 2004 study, employment on campus was the only form of financial aid that contributed significantly to degree completion.

Academic and social integration. Several of the primary theoretical models, including Tinto's interactionist model and Nora and Cabrera's (1996) student adjustment model, emphasize the importance of academic and social integration in college on 
persistence and degree completion. Tinto (1975) defines academic and social integration as the interactions occurring between the student and the academic and social systems of the institution over time. Similarly, Bean and Metzner (1985) define social integration as "the extent and quality of students' interaction with the social system of the college environment" (p. 507). Academic and social integration have been conceptualized using various measures in previous studies of degree completion. Typically, academic integration is viewed in terms of the frequency in which students interact with academic advisors, academic staff, and faculty members (Ishitani \& Desjardins, 2002; HahsVaughn, 2004) or engage in academic-related activities including career-related lectures and study groups (Nuñez \& Cuccaro-Alamin, 1998). In Nora and Cabrera's 1996 study, academic integration was represented by an academic experiences construct comprised of several survey items related to the level of concern faculty members exhibit towards students and the extent to which students have opportunities to interact with academic advisors, academic staff and faculty members. In their study, social integration was represented by a group of survey items related to the level to which the students developed relationships with their peers and met students of different backgrounds ( $p$. 144). Other measures of social integration most commonly included as predictors in previous models are: student participation in campus groups or clubs, involvement in community service, and meeting with faculty members outside of class (Bean \& Metzner, 1985; Astin \& Oseguera, 2005).

Previous research indicates first-generation students tend to have lower levels of academic and social integration in college. Regarding academic integration, there is evidence first-generation students spend less time than continuing generation students 
engaging in academic activities including studying and interacting with faculty. For example, Kim and Sax (2009) found first generation students interact with faculty on research-related activities and during class less frequently than continuing generation students. According to Pike and Kuh (2005), first generation students reported significantly lower levels of engagement in academic activities including library and writing experiences, active and collaborative learning, and interactions with faculty. First-generation students are also less likely to engage in activities characterized as social integration including meeting with faculty outside of class, developing relationships with other students, and participating in campus activities (Nuñez \& Cuccaro-Alamin, 1998; Pascarella, Pierson, Wolniak, \& Terenzini, 2004).

The tendency of first generation students to have lower levels of academic and social integration may be explained in part by the fact that as a group, the students have more difficulty than continuing generation students adjusting to college academically and socially (Terenzini, Rendon, Upcraft, Millar, Allison, Gregg, \& Jalomo, 1994). For example, after finding an association between age and both academic and social integration, Nuñez and Cucarro-Alamin (1998) posit first generation students may have lower academic and social integration levels because they tend to be older than continuing generation students and age may be a potentially limiting factor in the amount of time students can devote to and their interest in campus activities. In an analysis of data collected on 3,000 undergraduates in the College Student Experiences Questionnaire (CSEQ), Pike and Kuh (2005) provide evidence to suggest first generation students are less likely to be academically and socially engaged in large part because of lower 
educational aspirations and living off campus, while being first generation has more of an indirect effect on their level of academic and social engagement.

\section{The Role of Cultural and Social Capital in First Generation Student Success}

Bourdieu's theory of social reproduction, a theory rooted in sociology and sometimes used to frame educational attainment research, may be useful in shedding light on factors of first generation student success. It hypothesizes that cultural capital may help explain inequalities in the academic success of students (Bourdieu, 1986). Cultural capital is a set of skills and knowledge, specific to a social class, transmitted by parents to their children, that along with the economic investments of the monetary costs of schooling and time is a determinant of academic ability (p. 244) and by extension

educational outcomes. According to Bourdieu, the unequal distribution of cultural capital across social classes can help to explain differences in students' academic success (p. 243). According to McDonough (1997), the importance of cultural capital to educational attainment lies in how it influences a student's disposition towards education. Parents communicate the value of education to their children which in turn encourages the student to invest the time, effort, and money necessary to earn a college education (p. 9). Social capital consists of the resources stemming from an individual's network of relationships or his or her membership in a social group (Bourdieu, 1986).

Bourdieu's concepts of cultural and social capital have been used as a framework by higher education scholars to explain differences in educational access and outcomes. For example, in research conducted on the college-choice process and on postsecondary educational outcomes, Bourdieu's vision of cultural capital has been interpreted practically as the information that is useful in successfully navigating educational 
systems (McDonough \& Nuñez, 2007, p. 147), counseling opportunities and the availability of information sharing about college (McDonough, 1997) and privileged information and cultural practices potentially impacting positive educational outcomes (Nuñez, 2005). College knowledge was defined by York-Anderson and Bowman (1991) as knowledge of activities related to college life as well as the offices on campus and their assessment of the student's level of college knowledge included items such as if students know how to schedule time to study and if students are aware of career services. Pascarella, Pierson, Wolniak, and Terenzini (2004) argue cultural capital helps students to make informed decisions about involving themselves in college in ways that later lead to success. DiMaggio and Mohr (1985) posit cultural capital, defined in their study as knowledge of high society arts and culture, impacts educational attainment by providing students with access to an environment where education is valued and by making available resources such as opportunities to receive help from teachers and information about educational opportunities.

McDonough and Nuñez (2007) make a similar point about social capital, noting social capital has come to be viewed in practice as the relationships with teachers, counselors, and other individuals who advise students on educational choices as they progress through the educational landscape. These relationships facilitate access to information needed to successfully navigate the educational environment (p. 147) and succeed in college. Berger (2000) suggests the process of optimizing capital resources, or the information, skills, and knowledge that make up cultural capital, can affect student persistence and retention. Extending upon this idea, McDonough and Nuñez (2007) state attaining a degree "reflects not just the amount of academic skill one has developed 
in a particular disciple, but also reflects one's cultural and social advantages and the practices used to obtain that degree" (p. 146).

Specifically, several types of knowledge are associated with attaining success within the educational system including knowledge of how bureaucracies operate, knowledge on how to interact and develop relationships with school agents and peers who have access to academic circles, and knowledge of educational opportunities and how to overcome barriers (Stanton-Salazar, 1997, p. 12). However, research indicates first generation students are less likely to have access to this type of information about the college experience. After a review of research on the role of information and guidance in helping students enroll in college and obtain a college education, Vargas (2004) concludes first generation students lack knowledge in several areas including paying for college, connecting career and educational plans, preparing for college academically, and selecting a college that is a good fit with their interests. First generation students tend to lack access to information about how to choose a college that will be a good fit and are likely to lack knowledge on how to navigate the college environment, institutional expectations about academics, and how to meet their needs by interacting with the institution's bureaucratic systems (McDonough, 1997). According to Richardson and Skinner (1992), first-generation students lack important knowledge and skills that would help them succeed in college including time management skills and information about how to navigate some of the bureaucratic aspects of college including registering for classes, meeting with advisors, and choosing a major. First generation students are less likely than continuing generation students to work with their parents in planning for college (Choy, Horn, Nuñez \& Chen, 2000). While finding a college that 
matches a student's academic and social interests is a significant factor in college success (Braxton, Vesper, \& Hossler, 1995), first generation students are likely to lack knowledge of how to connect their career goals with their educational decisions (Arbona, 1994).

Unsurprisingly, parental education is positively related to the level of knowledge parents have on navigating the college environment to be able to share with their children. According to Horn and Nuñez (2000), as parental education increases, parents are more likely to attend programs providing information about educational opportunities and financial aid and attend school visits in which the student was deciding to apply to or enroll at the institution. According to Olson and Rosenfeld (1984), parental education relates positively to parental level of knowledge of financial aid. Similarly, McDonough (1997) posits parents who have attended college have greater knowledge on how to finance their children's college education.

Finally, research supports a potential relationship between the level of family support and parental involvement and access to college knowledge. According to YorkAnderson and Bowman (1991), while students who perceived more family support for attending college had more factual information about college, first generation students tended to perceive less support from their families than continuing generation students. A study conducted by Horn and Nuñez (2000) revealed first generation students were more likely than students whose parents had college degrees to never have had a discussion about college entrance exams or applying to college and parents of first generation students were less likely to search for financial aid information or visit a potential school with their child (p. 45). 
CHAPTER THREE

\section{METHODOLOGY}

\section{Methodological Overview}

This study uses a quantitative research design with a secondary data analysis to examine first generation student bachelor's degree completion. Logistic regression was the primary strategy employed to answer the following research questions:

1) To what extent can degree completion in six years be predicted by 1) first generation status, 2) student demographics, 3) pre-college academic performance and preparation variables, 4) college knowledge/cultural capital variables, and 5) college experience variables?

2) Which demographic, pre-college academic performance and preparation, cultural capital/college knowledge, and college experience variables predict bachelor's degree completion in six years for first generation students whose parents have no college experience, first generation students whose parents have some college experience, and continuing generation students and how do these factors vary for the three student groups?

\section{Overview of Data Source and Sample}

The data source for this study was the 2004/09 Beginning Postsecondary Students Longitudinal Study restricted access dataset (BPS:04/09). The Beginning Postsecondary Students Longitudinal Study (BPS) is a nationally representative, longitudinal survey of approximately 19,000 first-time students who enrolled in postsecondary education during the 2003-2004 academic year (Wine, Janson \& Wheeless, 2011). The sample for the 2004/09 Beginning Postsecondary Students Study was drawn from students initially 
surveyed in the National Postsecondary Student Aid Study (NPSAS), a cross-sectional study investigating how students and their families pay for higher education (Swail, 2009). At the end of data collection, it was determined 16,680 students had enough data to be classified as BPS study respondents. The BPS:04/09 dataset, representing students from 1,360 institutions, includes information collected from various sources including student interviews, transcript data requested from the postsecondary institutions attended by sample members, and administrative record matching to the Central Processing System (CPS), the National Student Loan Data System (NSLDS) and the National Student Clearinghouse (NCS) StudentTracker database (Wine, Janson, \& Wheeless, 2011). Data were collected on student demographic characteristics, family background, college experiences, persistence in higher education, and completion of two and four-year degree programs through the first interview in 2003 and in follow-up interviews at the end of the sample members' third (2005-2006) and sixth (2008-2009) years after entering postsecondary education.

\section{Sample for this Study}

The purpose of this study was to examine predictors of bachelor's degree completion for first generation students as compared to continuing generation students. Therefore, the sample for the study was limited to students who attended a 4-year institution. Many studies analyzing determinants of bachelor's degree completion limit the sample to students who begin at 4-year institutions (Ishitani, 2006; Lohfink \& Paulsen, 2005). However, the literature indicates first generation students are more likely to start their educational career at a community college. Among 1992 high school graduates who planned to enroll in a 4-year institution, approximately $20 \%$ of students 
whose parents did not attend college decided to enroll in a public 2-year institution instead of a 4-year institution as compared to nine percent of students whose parents earned a bachelor's degree or higher (Horn \& Nuñez, 2000).

Thus, limiting the sample only to those students who began at a 4-year institution runs the risk of excluding a potentially substantial number of first generation students who began at a 2-year institution and transferred to a 4-year institution from the analysis. Therefore, the study's sample was filtered to include both students who began at a 4-year institution and students who started at a 2-year institution and enrolled in a 4-year institution by June 2006. Respondents were included in the sample if the first institution level was a 4-year institution, or if the first institution level was a 2-year institution and they had attended a 4-year institution by 2006 . Students who started at a less than 2-year institution and had attended a 4-year institution by 2006 were excluded from the sample because there were fewer than 60 students in this category and only a handful of these students graduated with a college degree. As shown in Table 1, in this study's sample, higher percentages of first generation students started at a 2-year institution and later enrolled in a 4-year institution as compared to continuing generation students.

Table 1

First Institution Level by First Generation Status

\begin{tabular}{lcr}
\hline First generation status & $\begin{array}{c}\text { Started at 2-year } \\
\text { institution } \\
(\mathrm{n}=1090)\end{array}$ & $\begin{array}{c}\text { Started at 4-year } \\
\text { institution } \\
(\mathrm{n}=8470)\end{array}$ \\
\hline First generation-Parents did not attend college & $15.7 \%$ & $84.3 \%$ \\
First generation-Parents attended some college & $16.0 \%$ & $84.0 \%$ \\
Continuing generation & $11.7 \%$ & $88.3 \%$ \\
\hline $\begin{array}{l}\text { Note. Weighted with BPS:04/09 panel respondents weight (WTB000). Percentages reflect students enrolled } \\
\text { in a 4-year institution in the U.S. by 2006. }\end{array}$
\end{tabular}


Though a variable representing whether a respondent had attended a 4-year institution by 2009 exists in the dataset, this variable was not used to create the sample for two reasons. First, information for several of the college experience variables used in the study, such as academic and social integration, was collected in 2006 and represents the institution the respondent attended in 2006, not 2009. Therefore, if students who attended a 4-year institution after 2006 were included in the sample, the variables with information collected in 2006 would not represent the 4-year institution attended by these students in 2006. Second, the variable representing students who had ever attended a 4year institution by 2009 includes students who enrolled in a 4 -year institution between June 2006 and June 2009. It is possible some of these students, who enrolled in a 4-year institution three or more years after they entered postsecondary education, would graduate with a bachelor's degree, but most likely would not complete their degree by 2009 when degree attainment information was collected in the last follow up interview. Including these students in the sample would risk incorrectly coding a potentially significant number of graduates as non-graduates.

\section{Overview of Analytic Strategies}

\section{Logistic Regression}

Logistic regression was the main analytic strategy employed in this study because the dependent variable was a binary measure. A two part analysis was conducted with each part corresponding with a research question. To answer the first research question, a logistic regression model was created to determine whether first generation status is a predictor of bachelor's degree completion within six years. To answer the second 
research question, three logistic regression models were created to examine whether degree completion predictors vary by first generation status.

\section{Research Question 1}

Dependent and independent variables. The dependent variable for the logistic regression model used to answer the first research question was graduation status or bachelor's degree attainment six years after enrolling in college. The variable was coded " 1 " for students who graduated with a bachelor's degree and " 0 " for those who did not graduate with a bachelor's degree within six years. First generation status along with four categories of previously identified determinants of degree completion were added to the model as independent variables: 1) student demographics, 2) pre-college academic performance and preparation variables, 3) college knowledge/cultural capital variables, and 4) college experience variables because the model was used to determine whether first generation status predicts bachelor's degree completion within six years.

\section{Research Question 2}

Dependent and independent variables. To answer the second research question, three logistic regression models were created, each containing a different subgroup of students as categorized by their first generation status. The dependent variable for each of the three logistic regression models was graduation status or bachelor's degree attainment six years after enrolling in college. The variable was coded "l" for students who graduated with a bachelor's degree and " 0 " for those who did not graduate with a bachelor's degree within six years. The three models have the same independent variables used in the model for the first part of the analysis, except for first generation status. 
First generation status was used to create the sample for each of the three models because the three models were created to examine whether degree completion predictors vary by first generation status. Model 1 identifies the factors of degree attainment for first generation students whose parents have no college experience. Model 2 identifies the factors of degree attainment for first generation students whose parents have some college experience. Model 3 identifies the factors of degree attainment for continuing generation students.

The same four categories of independent variables including: 1) student demographics, 2) pre-college academic performance and preparation variables, 3) college knowledge/cultural capital variables, and 4) college experience variables related to academic and social integration added to the model in part one of the analysis were added to the three logistic regression models in part two.

\section{First Generation Status}

First generation status was an independent variable in the model for the first part of the analysis and was used to create the samples for the three models in the second part of the analysis. Respondents' first generation status was identified using the BPS:04/09 variable (PAREDUC) which indicates the highest level of education of either parent of the respondent as of 2003. As shown in Table 2, the PAREDUC variable contains ten categories of parental education ranging from "Did not complete high school" and "Doctoral degree or equivalent." Respondents who chose the eleventh category "Do not know parent's education level" were excluded from the analysis. Table 2 displays the percentages of respondents in each parental education category for the sample of BPS:0409 respondents selected for this study. 
Table 2

Highest Level of Parental Education

\begin{tabular}{lr}
\hline Parental level of education category & Percentage of respondents \\
\hline Do not know parent's education level & $1.4 \%$ \\
Did not complete high school & $3.6 \%$ \\
High School diploma or equivalent & $19.3 \%$ \\
Vocational or technical training & $3.8 \%$ \\
Less than two years of college & $7.3 \%$ \\
2 or more years of college but no degree & $7.2 \%$ \\
Associate's degree & $5.1 \%$ \\
Bachelor's degree & $26.4 \%$ \\
Master's degree or equivalent & $17.6 \%$ \\
First professional degree & $3.3 \%$ \\
Doctoral degree or equivalent & $5.0 \%$ \\
\hline
\end{tabular}

Note. Weighted with BPS:04/09 panel respondents weight (WTB000). Percentages reflect students enrolled in a 4-year institution in the U.S. by 2006.

\section{First Generation Student Definition}

The term "first generation student" is generally understood as a student who is the first in his or her family to attend college. The classification of students as first generation or continuing generation is typically based on the highest level of education attained by the student's parents and the particular level of parental education chosen to designate first generation status varies in the literature. In the original conceptualization of first generation status in higher education research studies, first generation students are defined as those whose parents' highest level of education was a high school diploma or less and continuing generation students as those whose parents attended some college or received a degree and many persistence and degree completion studies use this definition to classify students (Terenzini et al., 1996; Lohfink \& Paulsen, 2005). However, in more 
recent research, scholars have attempted to take into to account the possible difference between students whose parents have not attended college and students whose parents have attended some college. In a series of studies conducted by MPR Associates, Inc. for the National Center for Education Statistics, the researchers placed students into three categories: 1) First Generation-No College neither parent attended college; 2) First Generation-Some College- one or both parents had some post-secondary education including vocational/technical education but neither parent had attained a bachelor' degree; and 3) College Graduate - one or both parents earned a bachelor's degree or higher (Nuñez \& Cuccaro-Alamin, 1998; Horn \& Nuñez, 2000; Warburton, Bugarin \& Nuñez, 2001; Chen \& Carroll, 2005). In their studies, Bui (2002) and Ishitani (2006) separated students whose parents have some college experience from those whose parents have no college experience. At the other end of the spectrum, a few studies designate first generation status to students whose parents have not attained a bachelor's degree (Pike \& Kuh, 2005; Schultz, 2012).

\section{First Generation Status Independent Variables}

To address the first research question examining whether first generation status and other categories of variables predict bachelor's degree attainment, first generation status was included in the model as an independent variable. To ensure a robust analysis, two independent variables representing first generation status were created using the classification method from early studies of first generation students and the method used in recent studies of first generation students.

For the First Generation-Original Definition independent variable, respondents were grouped into two categories mirroring models in early studies: 1) First Generation 
(students whose parents' highest level of education is a high school diploma or less) and 2) Continuing Generation (students whose parents have some college experience including vocational or technical training, or earned an Associate's degree or higher). Therefore, respondents who chose "Did not complete high school", or "High school diploma or equivalent" were classified in the first category: First Generation. Respondents in all other level of parental education categories were classified in the second category: Continuing Generation.

For the First Generation-Updated Definition independent variable, students were classified using the three-category model present in the majority of recent studies: 1) First Generation-No College (students whose parents' highest level of education is a high school diploma or less) 2) First Generation-Some College (students whose parents have some college experience including vocational/technical training or earned an associate's degree) and 3) Continuing Generation (students whose parents earned a bachelor's degree or higher). Therefore, respondents who chose "Did not complete high school," or "High school diploma or equivalent" were placed in the first category: First GenerationNo College. Responses in the "Less than two years of college," "2 or more years of college but no degree," "Vocational or technical training," or "Associate's degree" were placed in the second category: First Generation-Some College. Respondents who answered the highest level of education of either parent as a Bachelor's degree or higher were included in the third category: Continuing Generation.

\section{First Generation Status Subgroups}

To address the second research question examining how the predictors of degree completion vary by first generation status, three models were created with each model 
containing a different subgroup of students as categorized by their first generation status. The sample for Model 1 is first generation students whose parents have no college experience and includes respondents who chose "Did not complete high school" or "High school diploma or less" for the highest level of parental education. The sample for Model 2 is first generation students whose parents have some college experience and includes respondents who chose "Less than two years of college," "2 or more years of college but no degree," "Vocational or technical training," or Associate's degree as the highest level of parental education. The sample for Model 3 is continuing generation students and includes respondents who chose Bachelor's degree or higher as the highest level of parental education.

\section{Independent Variables}

Several theories and models of student persistence and degree completion informed the independent variables chosen for inclusion in this study's degree completion model (Tinto, 1975; Astin, 1975; Bean, 1979; Nora \& Cabrera, 1996; Nuñez \& Cuccaro-Alamin, 1998; Adelman, 1999; Ishitani, 2003; Astin \& Oseguera, 2005). Using the categories of variables identified in existing theoretical and empirical degree completion models, variables from the BPS:04-09 dataset were selected for inclusion in the logistic regression models for the first and second analyses. The four categories of independent variables were: 1) student demographics 2) pre-college academic performance and preparation variables 3) college knowledge/cultural capital variables and 4) college experience variables. Table 3 provides descriptions and summarizes the coding scheme for the dependent variable and all independent variables used in this study. 


\section{Student Demographics}

The first category of variables, student demographic characteristics, is included in this study's model because previous degree completion studies designed their models to control for gender, race, and some measure of socio-economic status (Adelman, 1999; Ishitani, 2003). It is important to control for demographic characteristics because first generation students are more likely to be female, belong to a minority race/ethnic group, and belong to a low socioeconomic group (Nuñez \& Cuccaro-Alamin, 1998).

Gender and race/ethnicity variables were pulled directly from the student characteristics variables included in the (BPS:04-09) dataset. Socioeconomic status is represented by the RISKINDX variable, an index of seven characteristics negatively associated with degree attainment. The characteristics include delayed enrollment, no high school diploma, part-time enrollment, financially independent, have dependents, single parent status, and working full time while enrolled. In addition to representing socioeconomic status, this variable models the risk index used by Berkner, CuccaroAlamin, McCormick and Bobbitt (1996) to represent the factors theorized to hinder degree attainment.

\section{Pre-College Academic Performance and Preparation}

Variables representing pre-college academic performance and preparation were selected for inclusion in the model because performance in high school has been shown to be one of the most salient predictors of degree completion. Degree completion studies including Adelman (1999) and Astin and Oseguera (2005) used a combination of high school GPA, high school rank, and SAT/ACT test scores to represent pre-college academic performance. For this study, two of the pre-college academic performance 
variables used by Adelman (1999) and Astin and Oseguera (2005), high school GPA and high school rank, were selected for this study's model. The BPS:04/09 variable HCGPAREP represents the respondent's self-reported GPA on a test questionnaire filled out on the student's standardized test date. High school GPA was recoded into five ranges from seven ranges due to small numbers of cases in the " $D$ - to $D$ " and "D to C-" ranges. The cases from these two ranges were included in a " $\mathrm{C}$ and below" category. Standardized test scores were excluded as a pre-college academic performance variable because the SAT scores variable was used to create another variable in the model: academic fit. Two variables included in a model cannot have a direct relationship, so SAT score was excluded from the model. In addition to high school GPA and high school rank, a variable with the highest math course taken by the respondent in high school and a variable representing the rigor of the respondent's high school curriculum were included as pre-college academic performance based on empirical evidence of their impact on degree completion (Adelman, 2004; Astin \& Oseguera, 2005; Warburton, Bugarin, \& Nuñez, 2001). The variable representing the rigor of the respondent's high school curriculum is a yes/no item indicating whether the high school curriculum taken by the respondent would have met the rigorous high school curriculum requirements as set by the federal Academic Competitiveness Grants (ACG) program if the program had been in effect in 2003-2004. A "yes" on this item indicates the high school curriculum taken by the respondent met rigorous curriculum requirements as set by the ACG.

Before pre-college academic performance variables were added to the models, correlations between the variables were examined to identify possible instances of multi- 
collinearity. The results of the correlation analyses showed high school GPA was highly correlated with high school rank ( $\mathrm{r}=0.68)$ and high school GPA was moderately correlated with highest level of high school mathematics $(\mathrm{r}=0.39)$. Therefore, high school rank was removed from the model to prevent multi-collinearity. High school rank was chosen for removal because data was missing for $62 \%$ of the sample, while high school GPA data was only missing for nine percent of the sample.

\section{Cultural Capital/College Knowledge}

Cultural capital conceptualized in previous research as access to information that is helpful in navigating the educational environment has been shown to play a role in educational attainment (DiMaggio \& Mohr, 1985; McDonough, 1997; Nuñez, 2005). For this study, the variables selected to represent cultural capital are related to the level of knowledge students possess about the college experience at the time of enrollment. The following variables from the (BPS:04/09) dataset related to college knowledge were selected for inclusion: 1) one variable representing dual enrollment CRDCL04 (whether students earned college credits in high school) 2) two variables representing the use of resources to select a college including PUBLST04 (if the student consulted a college guide with rankings), and CONSIDRB (if the student considered the institution's graduation rate) 3) one variable representing the availability of options: APPS04 (how many schools the student applied to) 4) whether a sibling attended college before the respondent and 4) four variables representing the institutional aspects considered by the student: program of study, cost, reputation, and location. The variables representing the four institutional aspects considered by the respondent were summed together to create an index variable ranging from zero to four. 


\section{College Experience}

Several theoretical models of student persistence and attainment, of which Tinto's (1975) model of student departure and Bean's (1979) model of student attrition are the most well-known, stress the importance of academic and social integration on persisting in and completing college. Activities demonstrating integration including interacting with faculty and other students and participation in campus activities and clubs may certainly impact the likelihood of graduation. However, there have been some critiques as to whether hypotheses about the relationship between academic and social integration and degree attainment apply to non-traditional students like first generation students. Research indicates first generation students are less engaged academically and socially than continuing generation students, and are less likely to integrate diverse experiences during their time in college (Pike \& Kuh, 2005). Engle and Tinto (2008) similarly found first generation students are "less likely to be engaged in the academic and social experiences that foster success in college, such as studying in groups, interacting with faculty and other students, participating in extracurricular activities, and using support services" (p. 3) because of financial reasons.

Academic and social integration. Two index variables from the BPS:04/09 dataset were added to the model to represent academic and social integration. The Academic Integration Index variable (ACAINX06) was calculated by taking the average of respondent scores on four survey items: the frequency of social contact with faculty, the frequency of talking with faculty about academic matters outside of class, the frequency of meeting with an academic advisor, and the frequency of participation in study groups. The Social Integration Index variable (SOCINX06) was calculated by 
taking the average of respondent scores on three survey items: the frequency of attendance at fine arts activities, the frequency of participation in school clubs, and the frequency of participation in intramural or varsity sports. The survey items were rated by respondents on a three point scale where Never $=0,1=$ Sometimes, and 2=Often. For both indices, the average scores from the items were multiplied by 100 for the purpose of producing a standardized index score. The dataset includes academic and social integration index scores for 2004 and 2006. The 2006 scores were selected because they represent the respondent's most recent institution and would account for cases when the respondents transferred from a community college to a four-year institution.

Academic fit. In a recent study, Light and Strayer (2001) investigated the impact on graduation of the match between student academic ability and college quality, finding that students are more likely to graduate when their academic ability measured in standardized test scores matches the quality of the college as measured by the institutional mean score for a standardized test.

A set of academic fit variables was added to the model. The academic fit variables were calculated by subtracting the students' SAT math and SAT verbal scores from the institution's SAT math and verbal estimated median scores. Two variables were created with one variable representing the difference between the student's SAT math score and the institution's estimated median SAT math score and the second representing the difference between the student's SAT verbal score and the institution's estimated median SAT verbal score. Student SAT scores, derived from SAT I math and verbal scores or ACT scores converted using a concordance table if the respondent only took the ACT, were used for the student SAT component of the academic match variable. 
Institutional SAT score information from the 2003-2004 academic year was drawn from the Integrated Postsecondary Education Data System (IPEDS) Data Center. The IPEDS ID numbers for the 4-year institutions attended by the respondents were drawn from the Postsecondary Education Transcript Study (PETS) datasets provided with the BPS:04-09 dataset. In cases where the respondent attended more than one institution, the last 4-year institution attended was selected for the calculation of the academic match variable.

Estimated SAT median scores for each institution were calculated and used as the denominator for the academic fit variables because institutions do not report mean or median SAT scores to IPEDS. Instead, institutions report the $25^{\text {th }}$ and $75^{\text {th }}$ percentile SAT scores. Thus, an estimated median SAT math score and an estimated median SAT verbal score were calculated for each institution for which information was available by taking the average of the $25^{\text {th }}$ and $75^{\text {th }}$ percentile SAT scores. Estimated median SAT scores have been used in previous research as a predictor variable in one study about the impact of institutionally-funded financial aid to predict institutions' net tuition revenue per student (Hillman, 2011) and another study to predict institutional 6-year graduation rates (Hosch, 2008).

Financial aid. The literature suggests a positive relationship between student persistence and financial aid, though the effect of financial aid varies depending on the point where students are in their college career (Fenske, Porter, \& DuBrock, 1999; Ishitani \& DesJardins, 2002). In particular, financial aid has a positive relationship with student persistence for at-risk populations including first generation college students (Ishitani, 2006). Cabrera, Nora, and Castaneda (1992) posit financial aid indirectly 
impacts persistence. Findings from their single institution study indicate receiving financial aid in some form helped students to relieve financial burdens and concerns, allowing them to increase their academic and social involvement, two factors that impact persistence.

One variable related to financial aid and the cost of college was added to the model. The variable represents the college cost assumed by the student in the first year of enrollment in postsecondary education. This variable was chosen because the dollar amount of financial aid received by a student varies depending on institutional cost. The variable selected for inclusion, NETCST1, indicates the total net price of attendance after subtracting all financial aid for the 2003-2004 academic year and represents the estimated "out of pocket" cost to the student. The price of attendance variable was included in the dataset and was calculated for each respondent by subtracting total aid from the student's total budget, which includes tuition, fees, room and board, books, transportation, and personal expenses. For this analysis, the variable was recoded into ranges of $\$ 5000$.

Student major. A variable representing the number of times the respondent changed majors was included as a college experience variable because recent research suggests a positive relationship between changing majors and degree completion (Murphy, 2000; Foraker, 2012).

Starting at a two-year institution. A variable representing whether the respondent started at a community college was added to the model because research suggests first generation students are more likely to graduate if they start at a 4-year institution (Engle \& Tinto, 2008). Among first-time students entering postsecondary education during the 1995-1996 academic year who began at a 2-year institution, only 
$6 \%$ of first generation students completed a bachelor's degree in six years, while $16 \%$ of continuing generation students, whose parents' highest level of education is a bachelor's degree, and $25 \%$ of continuing generation students, whose parents' highest level of education is an advanced degree, completed a bachelor's degree in six years. For those students who started at a 4 -year institution, $43 \%$ of first generation students, $66 \%$ of continuing generation students, whose parents' highest level of education is a bachelor's degree, and $74 \%$ of continuing generation students, whose parents' highest level of education is an advanced degree, completed a bachelor's degree in six years (Snyder, Tan, \& Hoffman, 2006, p. 506).

Table 3

Description of Independent Variables

\begin{tabular}{|c|c|c|}
\hline Variable & Coding & Source \\
\hline \multicolumn{3}{|l|}{ Student demographics } \\
\hline Gender & $1=$ Male, $0=$ Female & BPS:04/09 \\
\hline Asian & $1=$ Yes, $0=$ No & BPS:04/09 \\
\hline Black or African American & $1=$ Yes, $0=$ No & BPS:04/09 \\
\hline Hispanic or Latino & $1=$ Yes, $0=$ No & BPS:04/09 \\
\hline Other Race/Ethnicity & $1=$ Yes, $0=$ No & BPS:04/09 \\
\hline White & $1=$ Yes, $0=$ No & BPS:04/09 \\
\hline Risk index & $\begin{array}{l}\text { Continuous, minimum }=1 \text {, } \\
\text { maximum }=7\end{array}$ & BPS:04/09 \\
\hline \multicolumn{3}{|l|}{$\begin{array}{l}\text { Pre-college academic performance and } \\
\text { preparation }\end{array}$} \\
\hline High school GPA & $\begin{array}{l}1=(C \text { and below }), 2=(C \text { to } \\
B-), 3=(B-\text { to } B), 4=(B \text { to } \\
A-), 5=(A-\text { to } A)\end{array}$ & $\begin{array}{l}\text { Derived from } \\
\text { BPS:04/09 }\end{array}$ \\
\hline High school rank & $\begin{array}{l}1=\text { Top quarter, } 2=\text { Second } \\
\text { quarter, } 3=\text { Third quarter, } \\
4=\text { Fourth quarter }\end{array}$ & BPS:04/09 \\
\hline Highest math course in high school & & BPS:04/09 \\
\hline Calculus & $1=$ Yes, $0=$ No & \\
\hline Pre-calculus & $1=$ Yes, $0=$ No & \\
\hline Trigonometry/algebra II & $1=$ Yes, $0=$ No & \\
\hline None & $1=$ Yes, $0=$ No & \\
\hline
\end{tabular}




\begin{tabular}{|c|c|c|}
\hline Variable & Coding & Source \\
\hline Took rigorous high school curriculum & $1=$ Yes, $0=$ No & BPS:04/09 \\
\hline \multicolumn{3}{|l|}{ Cultural capital/College knowledge } \\
\hline Dual enrollment & $1=\mathrm{Yes}, 0=\mathrm{No}$ & BPS:04/09 \\
\hline Number of schools applied to & $\begin{array}{l}\text { Continuous, minimum }=1 \text {, } \\
\text { maximum }=20\end{array}$ & BPS:04/09 \\
\hline Consulted published list of colleges & $1=$ Yes, $0=$ No & BPS:04/09 \\
\hline Considered institution's graduation rate & $1=$ Yes, $0=$ No & BPS:04/09 \\
\hline Institutional aspects considered index & $\begin{array}{l}\text { Continuous, } \text { minimum }=0 \text {, } \\
\text { maximum }=4\end{array}$ & $\begin{array}{l}\text { Derived from } \\
\text { BPS:04/09 }\end{array}$ \\
\hline Sibling in college before respondent & $1=$ Yes, $0=$ No & BPS:04/09 \\
\hline \multicolumn{3}{|l|}{ College experience } \\
\hline Academic fit & Continuous & $\begin{array}{l}\text { BPS:04/09 } \\
\text { IPEDS }\end{array}$ \\
\hline Academic integration index & $\begin{array}{l}\text { Continuous, minimum }=25, \\
\text { maximum }=200\end{array}$ & BPS:04/09 \\
\hline Changed major & & BPS:04/09 \\
\hline More than one time & $1=$ Yes, $0=$ No & \\
\hline One time & $1=$ Yes, $0=$ No & \\
\hline Never & $1=$ Yes, $0=$ No & \\
\hline Price of attendance 2003-2004 & $\begin{array}{l}\text { Continuous, minimum }=0 \text {, } \\
\text { maximum }=51970\end{array}$ & $\begin{array}{l}\text { Derived from } \\
\text { BPS:04/09 }\end{array}$ \\
\hline Social integration index & $\begin{array}{l}\text { Continuous, minimum }=33 \text {, } \\
\text { maximum }=200\end{array}$ & BPS:04/09 \\
\hline Started at a 2-year institution & $1=$ Yes, $0=$ No & BPS:04/09 \\
\hline
\end{tabular}

\section{Missing Data}

Table 4 outlines the percentage of missing values for each of the independent variables considered for the analysis. As described above, high school grade point average was highly correlated with high school class rank. The decision was made to omit high school class rank from the final models because $62 \%$ of the cases had missing values as compared to the nine percent of cases missing values for high school grade point average. Academic fit variables were unable to be calculated for $41 \%$ of the sample due to missing institution information because the student's transcripts were not included 
in the PETS dataset or because the institution did not submit SAT $25^{\text {th }}$ and $75^{\text {th }}$ percentile scores to IPEDS. Institutions are not required to submit SAT score information if SAT scores are not required for admission. After testing for significance and improvement to model prediction, the decision was made to omit the academic fit variables from the final model due to the high percentage of missing cases (41\%). Additionally, the variable representing the number of times the students changed major was omitted from the final model based on the same criteria of having a high percentage of missing data, significance testing, and model prediction improvement.

Cases with missing data for three variables including high school grade point average, rigor of high school curriculum, and whether or not the student earned college credit in high school were excluded from the analyses because the SPSS Complex Samples module handles missing data using listwise deletion, a method in which any cases with missing data for one or more of the independent variables are dropped from the analysis. Cases with missing data for rigor of high school curriculum are identical to the cases with missing data for the college credit earned in high school variable because data were not collected for either variable if respondents were over the age of 24 in 2003. High school grade point average was included only for respondents who were under the age of 24 and who received a high school diploma.

To minimize the loss of cases in the sample, mean imputation was used to assign values to the cases with missing academic and social integration index values. The academic and social integration index variable means were calculated for the entire sample for the models used for research question one and the missing values were substituted with the mean values. The academic and social integration index variable 
means were calculated for the samples used in the three models for research question two: first generation students whose parents have no college experience, first generation students whose parents have some college experience, and continuing generation students. The appropriate mean values were substituted for the missing values in each student group. Mean imputation was not used for high school grade point average, rigor of high school curriculum, earned college credit in high school, and number of times respondent changed majors variables because the variables are categorical.

Table 4

Missing Values by Independent Variable

\begin{tabular}{lr}
\hline Variable & $\begin{array}{r}\text { Percent Missing } \\
(\mathrm{n}=9670)\end{array}$ \\
\hline Student demographics & \\
Gender & $0.0 \%$ \\
Race/ethnicity & $0.0 \%$ \\
Risk index & $0.0 \%$ \\
Sibling in college & $0.0 \%$ \\
Pre-college academic performance & \\
Highest level of high school math & $5.2 \%$ \\
High school class rank & $61.5 \%$ \\
High school grade point average & $9.0 \%$ \\
Rigor of high school curriculum & $5.2 \%$ \\
Cultural capital/College knowledge & \\
Consulted list of colleges & $0.0 \%$ \\
Considered graduation rate & $0.0 \%$ \\
Earned college credit in high school & $5.2 \%$ \\
Number of colleges applied to & $0.0 \%$ \\
Reasons considered index & $0.0 \%$ \\
College experiences & \\
Academic fit & $41.0 \%$ \\
Academic integration index & $4.8 \%$ \\
Number of major changes & $14.4 \%$ \\
Price of attendance 2003-2004 & $10.0 \%$ \\
Social integration index & $4.8 \%$ \\
Started at a 4-year institution & $0.0 \%$ \\
\hline
\end{tabular}




\section{Complex Sampling Design and Statistical Issues}

The BPS:04-09 dataset analyzed in this study was constructed using a complex sampling survey design in which sampling techniques including clustering and stratification were employed. Standard analyses performed using data analysis software packages assume datasets were constructed using simple random sampling (Thomas \& Heck, 2001); therefore variance estimates are based on the assumptions of a simple random sample (Dowd \& Duggan, 2001, p. 6). Analyzing a complex sample as if it were a simple random sample will result in incorrect point and variance estimates and will not produce appropriate standard errors. Two of the assumptions of a simple random sample, equal weighting of observations and independence of observations are problematic when applied to an analysis of data collected using a complex sampling design. First, when stratification techniques are used to create subgroups of interest to draw samples from, oversampling occurs as individuals are sampled from certain subgroups disproportionally to ensure there are sufficient numbers of each subgroup for analysis (Thomas \& Heck, 2001, p. 520). Second, assuming simple random sampling ignores the similarities of individuals within groups, for example, in the case of the BPS:04-09 dataset, the similarities of students within institutions.

\section{Adjusting for Design Effects}

To adjust for the design effects of oversampling and non-independent observations, this study used Complex Samples in SPSS, a module that incorporates a complex sample design into the analysis. The module computes Taylor series variance estimates that are adjusted for design effects from complex sampling designs (Dowd \& Duggan, 2001) to produce appropriate standard errors. Variance statistics are computed 
based on a sampling weight, strata, and primary sampling units (p. 6), variables that are provided with the BPS:04-09 dataset.

For this analysis, the appropriate sampling weight, strata, and primary sampling unit variables were selected from the BPS:04-09 dataset and added to the dataset used in for the study's analyses. Next, a complex samples plan file containing the appropriate weight and sample design parameters was created using the Complex Samples module. Two sampling weights, WTA000 and WTB000 are provided with the BPS:04-09 dataset and it is noted in the dataset documentation either sampling weight is appropriate for an analysis using the data. Analyses weighted by WTA000 include study respondents, or those respondents who had sufficient data from the student interview or administrative sources to construct his or her enrollment history (Wine, Janson, \& Wheeless, 2011, p. iii). This weight was developed to compensate for the potentially biasing effects of study nonresponse (p. 127). Analyses weighted by WTB000 include panel respondents, or study respondents who responded to all three of the study waves, NPSAS: 04, BPS: 04/06, and BPS:04/09 (p.130). The WTB000 sampling weight was developed for analyzing the NPSAS: 04-BPS: 04/06-BPS:04/09 panel respondents (p. 127). The WTB000 sampling weight was chosen for this study's analysis because it is the default sampling weight used for National Center for Education Statistics (NCES) publications and for publically available frequency data including QuickStats and PowerStats.

Using SPSS Complex Samples requires the specification of a stratification variable and a clustering variable in the complex samples plan file. These variables are provided with the BPS:04-09 dataset and are selected by the researcher based on the type of variance estimation method supported by the chosen software package, either Taylor 
Series Linearization or Balanced Repeated Replicate (BRR) weights. SPSS allows for Taylor Series Linearization and two sets of variables for Taylor series variance estimation are provided with the dataset. The first set of variables is "used in software that assumes the first stage sampling units (institutions) were sampled with replacement and does not account for the finite population correction (FPC) at the institution level of sampling" (Wine, Janson, \& Wheeless, 2011, p. 121). The second set of variables is used in software that will account for without replacement sampling and for the FPC. The first set of variables, the strata variable BPS09STR, and the primary sampling unit (PSU) variable BPS09PSU were specified for this analysis. The parameters selected for this analysis including the "with replacement" method, the sampling weight, and the strata and primary sampling unit variables mirror the parameters specified for analyzing data with SPSS as outlined in a table on the use of weights and design parameters in selected survey data analysis software in Wine, Janson and Wheeless' 2011 full-scale methodology report for the BPS:04/09 data collection (p.123). 


\section{CHAPTER FOUR}

\section{RESULTS}

This study examined the relationship between first generation status and bachelor's degree completion, controlling for student background characteristics and other aspects of students' college experiences that have been identified as salient predictors in existing degree completion models. Also, this study sought to identify how factors influencing student success vary for first and continuing generation students and explored the impact on degree attainment of factors related to the level of college knowledge possessed by the student. This chapter presents the results of the analyses performed using data from the 2004-2009 Beginning Postsecondary Students Survey (BPS:04/09) restricted access dataset, in the context of the study's two research questions:

1) To what extent can degree completion in six years be predicted by 1) first generation status, 2) student demographics, 3) pre-college academic performance and preparation variables, 4) college knowledge/cultural capital variables, and 5) college experience variables?

2) Which demographic, pre-college academic performance and preparation, cultural capital/college knowledge, and college experience variables predict bachelor's degree completion in six years for first generation students whose parents have no college experience, first generation students whose parents have some college experience, and continuing generation students and how do these factors vary for the three student groups? 
Descriptive statistics for the study's sample, organized by first generation status, are presented in the first section of this chapter, followed by the results of the logistic regression analyses grouped by research question. The second section of this chapter provides the regression results for the first research question which examines the relationship between first generation status and degree completion after controlling for student demographics, pre-college academic performance and preparation, and college experience variables. The third section provides the regression results for the three models for the second research question which test whether the predictors of degree completion vary for the three groups of interest: first generation students whose parents have no college experience, first generation students whose parents have some college experience, and continuing generation students.

\section{Descriptive Statistics}

The sample of students for this study was drawn from the 2004-2009 Beginning Postsecondary Students Survey (BPS:04/09) restricted access dataset, a nationally representative, longitudinal survey of approximately 19,000 first-time students who enrolled in postsecondary education in during the 2003-2004 academic year (Wine, Janson \& Wheeless, 2011). Students who started at a 4-year institution or started at a 2year institution and had attended a 4-year institution by 2006 were included in the sample for this study. Table 5 displays selected descriptive statistics for the study's sample, organized by first generation status. 
Table 5

Selected Descriptive Statistics - Students Enrolled at a 4-Year Institution by 2006 (Percent)

\begin{tabular}{|c|c|c|c|c|}
\hline \multirow[b]{2}{*}{ Variable } & \multirow{2}{*}{$\begin{array}{c}\text { All } \\
\text { Students } \\
(n=9670)\end{array}$} & \multicolumn{3}{|c|}{ First Generation Status } \\
\hline & & $\begin{array}{c}\text { Parents did not } \\
\text { attend college } \\
(n=1960)\end{array}$ & $\begin{array}{l}\text { Parents attended } \\
\text { some college } \\
(n=2220)\end{array}$ & $\begin{array}{l}\text { Continuing } \\
\text { generation } \\
(\mathrm{n}=5380) \\
\end{array}$ \\
\hline $\begin{array}{l}\text { Six-year bachelor's } \\
\text { degree completion }\end{array}$ & 56.8 & 41.2 & 49.5 & 67.6 \\
\hline Gender: Female & 55.5 & 57.5 & 58.7 & 53.2 \\
\hline Asian & 5.9 & 6.0 & 3.2 & 6.5 \\
\hline $\begin{array}{l}\text { Black or African } \\
\text { American }\end{array}$ & 10.7 & 14.4 & 14.2 & 7.1 \\
\hline Hispanic or Latino & 10.5 & 18.2 & 11.2 & 6.7 \\
\hline Other Race/Ethnicity & 4.9 & 4.7 & 4.7 & 5.2 \\
\hline White & 68.1 & 56.8 & 66.7 & 74.6 \\
\hline $\begin{array}{l}\text { Earned college credits } \\
\text { in high school }\end{array}$ & 24.2 & 18.6 & 24.5 & 27.0 \\
\hline $\begin{array}{l}\text { Consulted a college } \\
\text { guide }\end{array}$ & 37.8 & 27.0 & 31.9 & 45.3 \\
\hline $\begin{array}{l}\text { Considered institution's } \\
\text { graduation rate }\end{array}$ & 46.6 & 38.8 & 45.7 & 50.7 \\
\hline $\begin{array}{l}\text { First generation-Parents } \\
\text { did not attend college }\end{array}$ & 23.2 & & & \\
\hline $\begin{array}{l}\text { First generation-Parents } \\
\text { attended some college }\end{array}$ & 23.7 & & & \\
\hline $\begin{array}{l}\text { Continuing generation } \\
\text { students }\end{array}$ & 53.0 & & & \\
\hline
\end{tabular}

Note. Weighted with BPS:04/09 panel respondents weight (WTB000). Percentages reflect students enrolled in a 4-year institution in the U.S. by 2006. First generation status subtotals do not add up to "All students" total because respondents choosing "Don't know" as highest level of parental education were excluded from subgroups.

Sample Demographics

In this study's sample, $23.2 \%$ of the students were first generation students whose parents did not attend college, $23.7 \%$ were first generation students whose parents attended some college and $53 \%$ were continuing generation students. The overall degree completion rate for students enrolled at a 4-year institution by 2006 was approximately 
$57 \%$. When comparing degree completion rates by first generation status, the rates for both groups of first generation students were lower than continuing generation students, at approximately $41 \%$ for first generation students whose parents have no college experience and $49 \%$ for first generation students whose parents have some college experience. The graduation rate for continuing generation students was substantially higher at approximately $68 \%$. Slightly over half of the students attending a 4-year institution were women (55.5\%). The gender distribution among the three groups of students was fairly similar, with women having slightly higher representation within the two first generation student groups, at $57.5 \%$ for first generation students whose parents have no college experience and $58.7 \%$ for first generation students whose parents have some college experience. In terms of race/ethnicity, the majority of students in the study's sample were White (68.1\%), while $10.7 \%$ identified as Black or African American, $10.5 \%$ as Hispanic or Latino, $5.9 \%$ as Asian and $4.9 \%$ identified as other race/ethnicity. Students who identified as Black/African American and Hispanic/Latino had higher representation in the first generation student groups as compared to the continuing generation student group.

\section{Differences in Predictors of Degree Completion}

Descriptively, when disaggregating by first generation status, differences in the predictors of degree completion become apparent. When examining the three variables representing college knowledge, lower percentages of first generation students whose parents have no college experience and first generation students whose parents have some college experience earned college credit in high school, consulted a college guide when applying to colleges, and considered the institution's graduation rate than did continuing 
generation students. Additionally, as shown in Table 6, on average, the institutional aspects considered index scores, comprised of how many of the four aspects of the institution were considered by the students during the college selection process, were lower for first generation students whose parents did not attend college (2.35) and first generation students whose parents attended some college (2.36) as compared to continuing generation students $(2.53)$.

Regarding other predictors of degree completion, the averages for the index of seven risk factors were higher for first generation students whose parents did not attend college (1.18) and first generation students whose parents attended some college (0.66) than for continuing generation students $(0.44)$ meaning, on average, first generation students have higher numbers of the risk factors associated with not completing a bachelor's degree. Also, both first generation student groups had lower average scores on the academic and social integration indexes than did continuing generation students.

Table 6

Selected Descriptive Statistics for Degree Completion Predictors (Means)

\begin{tabular}{lccc}
\hline & \multicolumn{3}{c}{ First Generation Status } \\
\cline { 2 - 4 } Variable & $\begin{array}{c}\text { Parents did not } \\
\text { attend college }\end{array}$ & $\begin{array}{c}\text { Parents attended } \\
\text { some college }\end{array}$ & $\begin{array}{c}\text { Continuing } \\
\text { generation }\end{array}$ \\
\hline Academic integration index & 90.39 & 93.34 & 98.99 \\
Social integration index & 53.09 & 57.06 & 74.03 \\
Institutional aspects considered & 2.35 & 2.36 & 2.53 \\
Risk factors index & 1.18 & 0.66 & 0.44 \\
\hline
\end{tabular}

\section{Research Question 1 Results}

The analysis to address research question one and determine whether the two conceptualizations of first generation status predict bachelor's degree completion when 
controlling for student demographic, pre-college academic performance and preparation, college knowledge/cultural capital, and college experience variables was performed using two logistic regression models. The dependent variable for each model was bachelor's degree attainment six years after enrolling in college. The independent variables from the following categories 1) student demographics, 2) pre-college academic performance and preparation variables, 3) college knowledge/cultural capital variables, and 4) college experience variables were added to the models simultaneously. First generation status was added as an independent variable to Model 1 as a two-category variable with the following categories 1) First Generation (students whose parents' highest level of education is a high school diploma or less) and 2) Continuing Generation (students whose parents have some college experience including vocational or technical training, or earned an Associate's degree or higher). First generation status with the following categories 1) First Generation-No College (students whose parents' highest level of education is a high school diploma or less) 2) First Generation-Some College (students whose parents attended some college including vocational/technical training or earned an associate's degree) and 3) Continuing Generation (students whose parents earned a bachelor's degree or higher), modeled using two dummy variables, was added to Model

2. The sample for both models was students who began at a 4-year institution or began at a 2-year institution and attended a 4-year institution by 2006.

\section{Overall Model Fit}

Several statistics were used to assess model fit for the two models and to determine which variables were included in the final models. Overall classification accuracy according to the model prediction results was considered and the log likelihood 
ratio was used to test for increases in the explanatory value of the model as each variable was added to the model. A decrease in the -2 Log Likelihood (-2LL) statistic when an independent variable is added to a model indicates an improvement in the model's ability to predict the dependent variable. Though pseudo $\mathrm{R}^{2}$ measures cannot be used in the same manner as the $\mathrm{R}^{2}$ measure in linear regression to indicate explained variation or be compared across datasets, pseudo $\mathrm{R}^{2}$ measures can be used to compare models using the same data and predicting the same outcome. An increase in a pseudo $\mathrm{R}^{2}$ measure when a variable or a set of variables are entered into a model indicates the model better predicts the outcome. For Model 1, in which first generation status was a two-category variable, the final Cox and Snell $\mathrm{R}^{2}=0.22$ and Nagelkerke $\mathrm{R}^{2}=0.30$. For Model 2, in which first generation status was a three-category variable, the final Cox and Snell $\mathrm{R}^{2}=0.23$ and Nagelkerke $\mathrm{R}^{2}=0.31$. The pseudo $\mathrm{R}^{2}$ values are approximately equal for the two models, indicating the two models have similar predictive ability. Sixteen of the nineteen variables along with first generation status were included in the final models. The three variables excluded from the model based on the criteria of percentage of missing data, significance testing, and model prediction improvement were academic fit, number of times student changed majors, and high school class rank.

Each category of independent variables was entered into a model independently and the pseudo $R^{2}$ measures were compared to evaluate the predictive ability of each set of independent variables. The pseudo $\mathrm{R}^{2}$ values for the sets of demographic variables, college experience variables, and pre-college academic preparation variables were approximately equal, indicating the sets had similar predictive ability, and the values were somewhat lower for the college knowledge variables. For the set of demographic 
variables that includes gender, race/ethnicity, and the risk factors index, the Cox and Snell $\mathrm{R}^{2}=0.13$ and Nagelkerke $\mathrm{R}^{2}=0.17$. For the set of college experience variables that includes the academic and social integration indices, the price of attendance, and starting at a 4-year institution, the Cox and Snell $\mathrm{R}^{2}=0.12$ and Nagelkerke $\mathrm{R}^{2}=0.17$. For the set of pre-college academic performance variables that includes high school grade point average, highest level of mathematics taken in high school, and took a rigorous high school curriculum, the Cox and Snell $R^{2}=0.12$ and Nagelkerke $R^{2}=0.16$. For the set of college knowledge variables that includes earning college credit in high school, consulting a published list of colleges, considering the institution's graduation rate, the number of schools applied to, the institutional reasons considered index, and having a sibling in college, the Cox and Snell $\mathrm{R}^{2}=0.06$ and Nagelkerke $\mathrm{R}^{2}=0.08$.

Model predictions. Table 7 shows the model prediction results for the two models. For Model 1, 83.7\% of students who graduated and $55.6 \%$ of students who did not graduate were predicted correctly. The overall prediction rate is $72.9 \%$. For Model 2 , $84.1 \%$ of students who graduated and $56.6 \%$ of students who did not graduate were predicted correctly. The overall prediction rate is $73.5 \%$. Model 2, in which the three category first generation status variable was added, had a slightly higher overall prediction rate and slightly higher pseudo $\mathrm{R}^{2}$ values than Model 1 .

\section{Table 7}

Summary Prediction for Models for Research Question 1

\begin{tabular}{ccc}
\hline Prediction & Model 1 & Model 2 \\
\hline Graduated (Correct) & $83.7 \%$ & $84.2 \%$ \\
Did not graduate (Correct) & $55.6 \%$ & $56.9 \%$ \\
Overall & $72.9 \%$ & $73.7 \%$ \\
\hline
\end{tabular}




\section{Major Findings for Research Question 1}

Table 8 shows the regression results for the two models to determine whether first generation status, defined differently in each model, predicts bachelor's degree completion after controlling for other variables. Included in Table 8 are the unstandardized logistic regression coefficients, odds ratios, and significance levels for each model. The unstandardized coefficient $(B)$ for each independent variable indicates the change in the log-odds of the dependent variable associated with a one-unit change in the independent variable. The odds ratio is calculated by taking the natural logarithm of $(B)$ and indicates the change in the odds of the dependent variable associated with a oneunit change in the independent variable. Odds ratios are generally included in the interpretation of logistic regression results because changes in odds are easier to interpret and understand than are changes in log-odds. Odds ratios greater than one indicate the increase in the odds of an outcome, in this case completing a bachelor's degree, associated with a one-unit change in the independent variable, while odds ratios less than one show the decrease in the odds of the outcome associated with a one-unit change in the independent variable (Tabachnick \& Fidell, 2001).

Eleven of sixteen variables were significant predictors of bachelor's degree completion in six years in both models including two demographic variables, all three pre-college academic preparation variables, two of the college knowledge variables, and all four of the college experience variables. Of the demographic variables, gender and the risk factors index were significant predictors of completing a degree. Being male was negatively associated with degree completion. To interpret odds ratios less than one, the odds ratio is subtracted from one and the resulting value indicates the percentage 
decrease in the odds of the outcome (Tabachnick \& Fidell, 2001, p. 549). As indicated by the odds ratio of 0.70 as shown in Table 8 , being male decreases the odds of completing a degree by $30 \%$. As the risk factors index increased, the likelihood of completing a degree decreased, meaning the more risk factors a student has the less likely the student is to complete his or her degree. For the pre-college academic preparation variables, the highest level of math taken in high school was a significant predictor. Students who took any math courses lower than calculus or did not take a math course in high school were less likely to complete a degree than students who took calculus. Increases in high school grade point average increased the likelihood of completing a degree. As indicated by the odds ratio of 1.36 shown in Table 8 , students who took a rigorous high school curriculum were approximately 1.4 times more likely to complete their degree.

Of the college experience factors, the academic and social integration indices, the price of attendance variable, and whether the student started at a 4-year institution were significant predictors of degree completion. The academic and social integration index scores had a positive relationship with completing a degree. Increases in the academic and social integration scores, or increases in the extent to which the student was academically and socially integrated, increased the likelihood of completing a degree. Increases in the price of attendance variable, or the out-of-pocket cost to the student, increased the likelihood of completing a degree. This finding should be interpreted with caution because it may be the case this variable is capturing several other effects in addition to the effect of the out-of-pocket cost of college attendance. First, the price of attendance variable could be capturing in part the effect of parental income. The amount 
of financial aid received by a student is related to family income, as students from lowincome families tend to receive higher amounts of aid and the price of attendance variable was calculated by subtracting all financial aid from the cost of tuition, books, and living expenses. Students from low-income families, or those students who would have lower out-of-pocket costs, tend to be less likely to complete degrees (Titus, 2006; Adelman, 2004; Bailey \& Dynarski, 2011; Cabrera, Burkum, \& La Nasa, 2005). Second, the price of attendance variable may be capturing some of the effect of institution type. Higher out-of-pocket costs may be related to the type of institution attended by the student because the cost of attending private institutions tends to be higher than the cost of attending public or for-profit institutions. Students who attend private institutions, or those students who would have higher out-of-pocket costs, tend to be more likely to complete degrees (Aud, Wilkinson-Flicker, Kristapovich, Rathbun, Wang, \& Zhang, 2013). Third, the price of attendance variable represents the out-of-pocket cost of the 2year institution attended by students who started at 2-year institution, a cost that is perhaps lower than the cost of the 4-year institution attended by these students. Finally, the price of attendance variable was only collected at one point in time and does not reflect changes in cost that may occur over a student's college career.

The effect of starting at a 4-year institution was negative, though this finding should be interpreted with caution as it may be an artifact of the unequal group sizes in the variable. Approximately ten percent of the sample started at a 2-year institution, while $90 \%$ started a 4-year institution. Additionally, it is important to clarify that this result indicates students who started their college career at a 4-year institution are less likely to graduate as compared to students who started their college career at a 2-year 
institution and successfully transferred to a 4-year institution, not as compared to all students who started at 2-year institution. Within this context the finding is reasonable because these students who successfully transfer from 2-year institutions potentially have an advantage over students who start at 4-year institutions when the outcome is completing a degree in six years. These students may be more likely to complete their degrees within the time limit of six years because by the time they attend a 4-year institution, they have their general courses completed and can focus on major courses. Thus, it would be unwise to interpret this result as evidence students should begin at a 2year institution.

Of the variables representing the student's level of college knowledge, having a sibling attend college before the student and the index comprised of a sum of the four aspects of the institution considered by the respondent during the college selection process were significant predictors of completing a degree. Students who had a sibling in college before they attended college were approximately 1.4 times more likely to complete a degree than students who did not have a sibling in college. The odds of completing a degree increased as the number of institutional aspects considered by the respondent increased.

Finally, first generation status was a significant predictor of bachelor's degree completion in both models. For Model 1, first generation students, classified as students whose parents have no college experience, are less likely to graduate than continuing generation students. For Model 2, both first generation students whose parents have no college experience and first generation students whose parents have some college experience were less likely to graduate than continuing generation students. 
Table 8

Summary of Model Results for Research Question I

\begin{tabular}{|c|c|c|c|c|c|c|}
\hline \multirow[b]{2}{*}{ Variable } & \multicolumn{2}{|c|}{$\begin{array}{c}\text { Model } 1 \\
(\mathrm{n}=7980)\end{array}$} & \multirow[b]{2}{*}{ Sig. } & \multicolumn{3}{|c|}{$\begin{array}{c}\text { Model } 2 \\
(\mathrm{n}=7980)\end{array}$} \\
\hline & $B$ & $\begin{array}{l}\text { Odds } \\
\text { Ratio }\end{array}$ & & $B$ & $\begin{array}{l}\text { Odds } \\
\text { Ratio }\end{array}$ & Sig. \\
\hline \multicolumn{7}{|l|}{ Student characteristics } \\
\hline Gender (Female) & -0.358 & 0.699 & $* * *$ & -0.371 & 0.690 & $* * *$ \\
\hline Asian (White) & -0.008 & 0.736 & & -0.021 & 0.979 & \\
\hline Black or African American (White) & -0.316 & 0.729 & & -0.285 & 0.752 & \\
\hline Hispanic or Latino (White) & -0.316 & 0.729 & & -0.292 & 0.747 & \\
\hline Other race/ethnicity (White) & -0.307 & 0.736 & & -0.301 & 0.740 & \\
\hline Risk index & -0.469 & 0.626 & $* * *$ & -0.471 & 0.624 & $* * *$ \\
\hline \multicolumn{7}{|l|}{ Pre-college academic performance } \\
\hline Pre-calculus (Calculus) & -0.389 & 0.677 & $* * *$ & -0.379 & 0.685 & $* * *$ \\
\hline Trigonometry/algebra II (Calculus) & -0.493 & 0.611 & $* * *$ & -0.484 & 0.616 & $* * *$ \\
\hline Algebra II (Calculus) & -0.850 & 0.428 & $* * *$ & -0.835 & 0.434 & $* * *$ \\
\hline None (Calculus) & -0.525 & 0.592 & ** & -0.509 & 0.601 & $* *$ \\
\hline High school grade point average & 0.408 & 1.504 & $* * *$ & 0.406 & 1.501 & $* * *$ \\
\hline Took rigorous high school curriculum & 0.305 & 1.357 & $* * *$ & 0.301 & 1.351 & $* * *$ \\
\hline \multicolumn{7}{|l|}{ Cultural capital/College knowledge } \\
\hline Consulted list of colleges & 0.094 & 1.099 & & 0.085 & 1.088 & \\
\hline Considered graduation rate & 0.041 & 1.042 & & 0.046 & 1.047 & \\
\hline Earned college credit in high school & 0.000 & 1.000 & & -0.002 & 0.998 & \\
\hline Number of colleges applied to & 0.022 & 1.022 & & 0.019 & 1.019 & \\
\hline Institutional aspects considered index & 0.136 & 1.146 & $* * *$ & 0.133 & 1.142 & $* * *$ \\
\hline Sibling in college & 0.306 & 1.358 & $* * *$ & 0.285 & 1.330 & $* * *$ \\
\hline \multicolumn{7}{|l|}{ College experiences } \\
\hline Academic integration index & 0.006 & 1.006 & $* * *$ & 0.006 & 1.006 & $* * *$ \\
\hline Price of attendance 2003-2004 & 0.160 & 1.174 & $* * *$ & 0.145 & 1.156 & $* * *$ \\
\hline Social integration index & 0.007 & 1.007 & $* * *$ & 0.007 & 1.007 & $* * *$ \\
\hline Started at a 4-year institution & -0.458 & 0.632 & $* * *$ & -0.458 & 0.632 & *** \\
\hline \multicolumn{7}{|l|}{ First generation status } \\
\hline Parents have no college experience & -0.241 & 0.786 & ** & -0.366 & 0.694 & $* * *$ \\
\hline Parents have some college experience & & & & -0.324 & 0.723 & $* * *$ \\
\hline
\end{tabular}

Note. ${ }^{* *} \mathrm{p}<0.01,{ }^{* * *} \mathrm{p}<0.001$. Reference categories are in parentheses. "Parents have some college experience" was not a category in Model 1. 


\section{Research Question 2 Results}

The analysis to address research question two, and determine if and how the significant predictors of degree completion vary for first generation students whose parents have no college experience, first generation students whose parents have some college experience, and continuing generation students, was performed using three logistic regression models. The dependent variable for each model was bachelor's degree attainment six years after enrolling in college. The independent variables from the following categories 1) student demographics, 2) pre-college academic performance and preparation variables, 3) cultural capital/college knowledge variables, and 4) college experience variables were added to the models simultaneously. To create the samples for the three models used to answer the second research question, the sample of students who started at a 4-year institution or started at a 2-year institution and enrolled in a 4-year institution by 2006 was further divided using first generation status. The sample for the first model was students whose parents' highest level of education is a high school diploma or less. The sample for the second model was students whose parents have some college experience including vocational/technical training or earned an associate's degree. The sample for the third model was students whose parents earned a bachelor's degree or higher.

\section{Overall Model Fit}

As with the logistic regression models used in the previous section, several statistics were used to assess model fit and to choose variables included in the final three models. Overall classification accuracy according to the model prediction results was considered and the likelihood ratio and pseudo $\mathrm{R}^{2}$ measures were used to test for 
increases in the explanatory value as variables were added to the model. For the final model for first generation students whose parents have no college experience, Cox and Snell $R^{2}=0.22$ and Nagelkerke $R^{2}=0.29$. For the final model for first generation students whose parents have some college experience, Cox and Snell $\mathrm{R}^{2}=0.23$ and Nagelkerke $R^{2}=0.31$. For the final model for continuing generation students, Cox and Snell $R^{2}=0.18$ and Nagelkerke $R^{2}=0.26$. The pseudo $R^{2}$ values were slightly higher for the model for first generation students whose parents have no college experience and the model for first generation students whose parents have some college experience, suggesting the two models better predict degree completion than does the model for continuing generation students. Sixteen variables were included in the final models. The three variables excluded from the model based on the criteria percentage of missing data, significance testing, and model prediction improvement were: academic fit, number of times student changed majors, and high school class rank.

Model predictions. Table 9 shows the model prediction results for the three models. For the first generation students whose parents have no college experience model, $69 \%$ of students who graduated and $73.9 \%$ of students who did not graduate were predicted correctly. The overall prediction rate is $71.5 \%$. For the first generation students whose parents have some college experience model, $76.6 \%$ of students who graduated and $68.2 \%$ of students who did not graduate were predicted correctly. The overall prediction rate is $72.6 \%$. For the continuing generation students model, $90.9 \%$ of students who graduated and $37.0 \%$ of students who did not graduate were predicted correctly. The overall prediction rate is $74.8 \%$. 
Table 9

Summary Prediction for Models by First Generation Status

\begin{tabular}{cccr}
\hline & \multicolumn{3}{c}{ First Generation Status } \\
Prediction & $\begin{array}{c}\text { Parents did not } \\
\text { attend college }\end{array}$ & $\begin{array}{c}\text { Parents attended } \\
\text { some college }\end{array}$ & $\begin{array}{c}\text { Continuing } \\
\text { generation }\end{array}$ \\
\hline Graduated (Correct) & $69.0 \%$ & $76.6 \%$ & $90.9 \%$ \\
Did not graduate (Correct) & $73.9 \%$ & $68.2 \%$ & $37.0 \%$ \\
Overall & $71.5 \%$ & $72.6 \%$ & $74.8 \%$ \\
\hline
\end{tabular}

\section{Major Findings for Research Question 2}

The regression results for the three models are summarized in Table 10. The significant predictors of bachelor's degree completion varied across the three logistic regression models for first generation students whose parents did not attend college, first generation students whose parents attended some college and continuing generation students. Consulting a college guide was a significant predictor of degree completion for first generation students whose parents have no college experience, but was not significant in the models for the other two groups of students. First generation students whose parents have no college experience who consulted a college guide were 1.4 times more likely to complete their degree than students who did not consult a college guide. The two groups of first generation students shared one significant predictor. Taking a rigorous high school curriculum significantly increased the likelihood of degree completion for first generation students whose parents have no college experience and first generation students whose parents have some college experience, but was not a significant predictor for continuing generation students. 
There were also similarities in the significant predictors for first generation students whose parents have no college experience and continuing generation students. Two of the college knowledge variables, whether a sibling attended college before the student and the institutional aspects considered index, as well as gender and starting at a 4-year institution were significant predictors for first generation students whose parents have no college experience and continuing generation students. Being male decreased the odds of graduating for both groups of students. First generation students whose parents have no college experience and continuing generation students who had a sibling attend college before them were more likely to graduate than students who did not have a sibling in college before them. As the institutional aspects considered index increased, students in these two groups were more likely to complete their degree. The effect of starting at a 4-year institution was negative, though this finding should be interpreted with caution because as mentioned previously, it may be an artifact of the unequal group sizes. Approximately ten percent of the sample started at a 2 -year institution, while $90 \%$ started a 4-year institution. Additionally, it is important to emphasize only students who started at a 2-year institution and successfully transferred to a 4-year institution are included, not all students who started at a 2-year institution. Thus, these students may be more likely to complete their degrees within the time limit of six years because by the time they attend a 4-year institution, they have their general courses completed and can focus on major courses.

Finally, first generation students whose parents have some college experience and continuing generation students shared two significant predictors, price of attendance and race/ethnicity. As the price of attendance increased, students in these two groups were 
more likely to complete their degrees. As mentioned previously, this result should be interpreted with caution because it is quite possible this variable is capturing effects other than the out-of-pocket cost, including the effect of parental income, institution type, and the lower cost of attending a 2-year institution for students who started at a 2-year institution. For first generation students whose parents have some college experience, students who indicated their race as Black or African American, Hispanic or Latino, or other race/ethnicity were less likely to graduate than students indicating their race as White. For continuing generation students, students who indicated their race as Hispanic/Latino were less likely to graduate than students indicating their race as White. Five of the variables including the risk factors index, high school grade point average, highest math course taken in high school, the academic integration index and the social integration index were significant predictors across all three models. For all three groups of students, increases in the number of risk factors as student has and taking any of the math courses lower than calculus or not taking a math course in high school had significant negative effects on the likelihood of completing a degree. For all three groups of students, increases in high school grade point averages were associated with increases in the odds of completing a degree. As scores on the academic and social integration indices increased, the odds of completing a degree increased. Three variables, including considering the institutional graduation rate when selecting a college, earning college credit in high school, and the number of colleges applied to, were not significant predictors in any of the models. The three variables that were not significant predictors for any of the groups of students were related to the level of college knowledge possessed by the student at the time of enrollment. 
Table 10

Summary of Model Results by First Generation Status

\begin{tabular}{|c|c|c|c|c|c|c|}
\hline \multirow[b]{3}{*}{ Variable } & \multicolumn{6}{|c|}{ First Generation Status } \\
\hline & \multicolumn{2}{|c|}{$\begin{array}{l}\text { Parents did not } \\
\text { attend college } \\
\quad(n=1520)\end{array}$} & \multicolumn{2}{|c|}{$\begin{array}{l}\text { Parents attended } \\
\text { some college } \\
\quad(n=1840)\end{array}$} & \multicolumn{2}{|c|}{$\begin{array}{l}\text { Continuing } \\
\text { generation } \\
(n=4610)\end{array}$} \\
\hline & $\begin{array}{l}\text { Odds } \\
\text { Ratio }\end{array}$ & Sig. & $\begin{array}{l}\text { Odds } \\
\text { Ratio }\end{array}$ & Sig. & $\begin{array}{l}\text { Odds } \\
\text { Ratio }\end{array}$ & Sig. \\
\hline \multicolumn{7}{|l|}{ Student characteristics } \\
\hline Gender: Male & 0.602 & $* * *$ & 0.886 & & 0.644 & $* * *$ \\
\hline Asian (White) & 1.484 & & 1.136 & & 0.812 & \\
\hline Black or African American (White) & 0.966 & & 0.647 & * & 0.806 & \\
\hline Hispanic or Latino (White) & 1.420 & & 0.483 & ** & 0.611 & ** \\
\hline Other race/ethnicity (White) & 1.155 & & 0.476 & * & 0.785 & \\
\hline Risk index & 0.632 & $* *$ & 0.571 & $* * *$ & 0.624 & $* * *$ \\
\hline \multicolumn{7}{|l|}{ Pre-college academic performance } \\
\hline Pre-calculus (Calculus) & 0.684 & & 0.528 & ** & 0.760 & * \\
\hline Trigonometry/algebra II (Calculus) & 0.594 & * & 0.600 & * & 0.614 & *** \\
\hline Algebra II (Calculus) & 0.452 & $* * *$ & 0.353 & $* * *$ & 0.451 & *** \\
\hline None (Calculus) & 0.737 & & 0.636 & & 0.520 & * \\
\hline High school grade point average & 1.680 & $* * *$ & 1.499 & *** & 1.440 & *** \\
\hline Took rigorous high school curriculum & 1.618 & $* *$ & 1.544 & ** & 1.191 & \\
\hline \multicolumn{7}{|l|}{ Cultural capital/College knowledge } \\
\hline Consulted list of colleges & 1.441 & * & 1.023 & & 1.038 & \\
\hline Considered graduation rate & 1.098 & & 1.031 & & 1.038 & \\
\hline Earned college credit in high school & 0.918 & & 1.091 & & 0.979 & \\
\hline Number of colleges applied to & 1.000 & & 0.983 & & 1.041 & \\
\hline Institutional aspects considered index & 1.209 & ** & 1.101 & & 1.132 & * \\
\hline Sibling in college & 1.381 & * & 1.240 & & 1.342 & ** \\
\hline \multicolumn{7}{|l|}{ College experiences } \\
\hline Academic integration index & 1.005 & ** & 1.008 & $* * *$ & 1.006 & *** \\
\hline Price of attendance 2003-2004 & 1.106 & & 1.241 & $* * *$ & 1.153 & $* * *$ \\
\hline Social integration index & 1.008 & $* * *$ & 1.007 & $* * *$ & 1.006 & $* * *$ \\
\hline Started at a 4-year institution & 0.489 & ** & 0.704 & & 0.672 & ** \\
\hline
\end{tabular}

Note. ${ }^{*} \mathrm{p}<0.05,{ }^{* *} \mathrm{p}<0.01,{ }^{* * *} \mathrm{p}<0.001$ 
First generation students model 1. Table 11 shows the regression results for the model for students whose parents did not attend college. Eleven of the 16 variables were significant predictors of degree completion for first generation students whose parents did not attend college including gender, the risk factors index, the highest math course taken in high school, high school grade point average, taking a rigorous high school curriculum, consulting a published list of college rankings during the college selection process, the institutional aspects considered index, a sibling attending college before the student, the academic integration index, the social integration index, and whether the respondent started at a 4-year institution. As indicated by the odds ratio of 0.60 as shown in Table 11 , being male decreased the odds of completing a degree by $40 \%$. Three variables had a significant negative effect on the likelihood of completing a degree. Increases in the risk factors index and taking a math course lower than calculus or not taking a math course in high school decreased the odds of completing a degree. Students starting at a 4-year institution were about half as likely to complete a degree as students who started at a 2year institution, though this finding should be interpreted with caution because the sizes of the two groups were unequal. As mentioned previously, approximately ten percent of the sample started at a 2 -year institution, while $90 \%$ started a 4 -year institution. Additionally, it is important to emphasize only students who started at a 2-year institution and successfully transferred to a 4-year institution are included, not all students who started at a 2-year institution. Thus, these students may be more likely to complete their degrees within the time limit of six years because by the time they attend a 4-year institution, they have their general courses completed and can focus on major courses. 
Seven variables including three college knowledge variables had significant positive effects on the likelihood of completing a degree for first generation students whose parents have no college experience. As with the other two student groups, for first generation students whose parents have no college experience, higher high school grade point averages and higher scores on the academic and social integration indices increased the odds of completing a bachelor's degree. Taking a rigorous high school curriculum was a significant predictor for first generation students whose parents have no college experience, as it was for first generation students whose parents have some college experience. First generation students whose parents have no college experience who took a rigorous high school curriculum were 1.6 times more likely to complete their degree than students who did not take a rigorous high school curriculum.

The three variables related to level of college knowledge possessed by the student that were significant predictors for first generation students whose parents have no college experience were consulting a college guide, the institutional aspects considered index, and a sibling attending college before the student. First generation students whose parents have no college experience who consulted a college guide were 1.4 times more likely to complete their degree than students who did not consult a college guide. As the number of institutional aspects considered by the student increased, the odds of completing a degree increased for first generation students whose parents have no college experience. Finally, first generation students whose parents have no college experience who had a sibling attend college before them were 1.4 times more likely to complete their degree than students who did not have a sibling attend college before them. 
Table 11

Binomial Logistic Regression Results, Individual Predictors of Completing Bachelor's Degree in Six Years for First Generation Students-Parents Have No College Experience

\begin{tabular}{|c|c|c|c|c|c|c|c|}
\hline \multirow[b]{2}{*}{ Variable } & \multirow[b]{2}{*}{$B$} & \multirow[b]{2}{*}{ SE } & \multirow{2}{*}{$\begin{array}{l}\text { Odds } \\
\text { Ratio } \\
\end{array}$} & \multirow[b]{2}{*}{ Sig. } & & \multicolumn{2}{|c|}{$\begin{array}{l}95 \% \text { Confidence } \\
\text { Interval for } \\
\text { Odds Ratio }\end{array}$} \\
\hline & & & & & & Upper & Lower \\
\hline \multicolumn{8}{|l|}{ Student characteristics } \\
\hline Gender: Male & -0.508 & 0.157 & 0.602 & 0.001 & *** & 0.442 & 0.819 \\
\hline Asian (White) & 0.395 & 0.309 & 1.484 & 0.201 & & 0.810 & 2.720 \\
\hline Black or African American (White) & -0.034 & 0.229 & 0.966 & 0.881 & & 0.617 & 1.514 \\
\hline Hispanic or Latino (White) & 0.350 & 0.212 & 1.420 & 0.099 & & 0.937 & 2.152 \\
\hline Other race/ethnicity (White) & 0.144 & 0.463 & 1.155 & 0.756 & & 0.465 & 2.866 \\
\hline Risk index & -0.458 & 0.149 & 0.632 & 0.002 & ** & 0.472 & 0.848 \\
\hline \multicolumn{8}{|l|}{ Pre-college academic performance } \\
\hline Pre-calculus (Calculus) & -0.380 & 0.234 & 0.684 & 0.104 & & 0.433 & 1.082 \\
\hline Trigonometry/algebra II (Calculus) & -0.521 & 0.222 & 0.594 & 0.019 & $*$ & 0.384 & 0.919 \\
\hline Algebra II (Calculus) & -0.794 & 0.232 & 0.452 & 0.001 & $* * *$ & 0.286 & 0.713 \\
\hline None (Calculus) & -0.305 & 0.334 & 0.737 & 0.383 & & 0.383 & 1.422 \\
\hline High school grade point average & 0.519 & 0.088 & 1.680 & 0.000 & $* * *$ & 1.415 & 1.996 \\
\hline Took rigorous high school curriculum & 0.481 & 0.176 & 1.618 & 0.006 & ** & 1.144 & 2.287 \\
\hline \multicolumn{8}{|l|}{ Cultural capital/College knowledge } \\
\hline Consulted list of college & 0.366 & 0.162 & 1.441 & 0.024 & * & 1.049 & 1.981 \\
\hline Considered graduation rate & 0.093 & 0.153 & 1.098 & 0.543 & & 0.812 & 1.484 \\
\hline Earned college credit in high school & -0.086 & 0.203 & 0.918 & 0.672 & & 0.616 & 1.366 \\
\hline Number of colleges applied to & 0.000 & 0.032 & 1.000 & 0.995 & & 0.939 & 1.064 \\
\hline Institutional aspects considered index & 0.190 & 0.063 & 1.209 & 0.002 & $* *$ & 1.069 & 1.367 \\
\hline Sibling in college & 0.323 & 0.139 & 1.381 & 0.021 & * & 1.051 & 1.815 \\
\hline \multicolumn{8}{|l|}{ College experiences } \\
\hline Academic integration index & 0.005 & 0.002 & 1.005 & 0.006 & $* *$ & 1.002 & 1.009 \\
\hline Price of attendance 2003-2004 & 0.101 & 0.068 & 1.106 & 0.138 & & 0.968 & 1.263 \\
\hline Social integration index & 0.008 & 0.002 & 1.008 & 0.000 & $* * *$ & 1.004 & 1.012 \\
\hline Started at a 4-year institution & -0.714 & 0.251 & 0.489 & 0.005 & ** & 0.299 & 0.802 \\
\hline
\end{tabular}

First generation students model 2. Table 12 shows the regression results for the model for students whose parents attended some college. Eight of the 16 variables were significant predictors of bachelor's degree completion for first generation students whose 
parents have some college experience including race/ethnicity, the risk factors index, the highest math course taken in high school, high school grade point average, taking a rigorous high school curriculum, the academic integration index, the social integration index, and the price of attendance. Three variables had significant negative effects on the probability of completing a degree. Students who indicated their race/ethnicity as Black or African American, Hispanic or Latino, or as Other race/ethnicity were less likely to complete degrees than students who indicated their race/ethnicity as White. Increases in the risk factors index and taking a math course lower than calculus or not taking a math course in high school decreased the odds of completing a degree for first generation students whose parents have some college experience.

Five variables had significant positive effects on the probability of completing a degree for first generation students whose parents have some college experience. Students who took a rigorous high school curriculum were 1.5 times more likely to complete their degree than students who did not take a rigorous high school curriculum. Increases in high school grade point averages and in the scores on the academic and social integration indices increased the odds of graduating with a degree. As was the case for continuing generation students, the price of attendance was a significant predictor for first generation students whose parents have some college experience. As the price of attendance increased, students were more likely to complete their degrees. As mentioned previously, this result should be interpreted with caution because this variable may be capturing effects other than the out-of-pocket cost, including the effect of parental income, institution type, and the lower cost of attending a 2-year institution for students who started at a 2-year institution. It is important to note none of the college knowledge 
variables were significant predictors for first generation students whose parents have some college experience.

Table 12

Binomial Logistic Regression Results, Individual Predictors of Completing a Bachelor's Degree in Six Years for First Generation Students-Parents Have Some College Experience

\begin{tabular}{|c|c|c|c|c|c|c|c|}
\hline \multirow[b]{2}{*}{ Variable } & \multirow[b]{2}{*}{$B$} & \multirow[b]{2}{*}{$\mathrm{SE}$} & \multirow{2}{*}{$\begin{array}{l}\text { Odds } \\
\text { Ratio } \\
\end{array}$} & \multirow[b]{2}{*}{ Sig. } & & \multicolumn{2}{|c|}{$\begin{array}{c}95 \% \\
\text { Confidence } \\
\text { Interval for } \\
\text { Odds Ratio }\end{array}$} \\
\hline & & & & & & Upper & Lower \\
\hline \multicolumn{8}{|l|}{ Student characteristics } \\
\hline Gender: Male & -0.121 & 0.149 & 0.886 & 0.419 & & 0.661 & 1.188 \\
\hline Asian (White) & 0.128 & 0.391 & 1.136 & 0.744 & & 0.527 & 2.450 \\
\hline Black or African American (White) & -0.435 & 0.202 & 0.647 & 0.031 & $*$ & 0.435 & 0.962 \\
\hline Hispanic or Latino (White) & -0.727 & 0.251 & 0.483 & 0.004 & $* *$ & 0.295 & 0.792 \\
\hline Other race/ethnicity (White) & -0.742 & 0.293 & 0.476 & 0.012 & $*$ & 0.268 & 0.846 \\
\hline Risk index & -0.561 & 0.112 & 0.571 & 0.000 & $* * *$ & 0.458 & 0.711 \\
\hline \multicolumn{8}{|l|}{ Pre-college academic performance } \\
\hline Pre-calculus (Calculus) & -0.638 & 0.202 & 0.528 & 0.002 & ** & 0.356 & 0.785 \\
\hline Trigonometry/algebra Il (Calculus) & -0.512 & 0.210 & 0.600 & 0.015 & $*$ & 0.397 & 0.905 \\
\hline Algebra II (Calculus) & -1.043 & 0.208 & 0.353 & 0.000 & $* * *$ & 0.234 & 0.531 \\
\hline None (Calculus) & -0.452 & 0.366 & 0.636 & 0.217 & & 0.310 & 1.305 \\
\hline High school grade point average & 0.405 & 0.077 & 1.499 & 0.000 & $* * *$ & 1.288 & 1.744 \\
\hline Took a rigorous high school curriculum & 0.434 & 0.164 & 1.544 & 0.008 & ** & 1.119 & 2.128 \\
\hline \multicolumn{8}{|l|}{ Cultural capital/College knowledge } \\
\hline Consulted list of colleges & 0.022 & 0.153 & 1.023 & 0.883 & & 0.757 & 1.381 \\
\hline Considered graduation rate & 0.031 & 0.150 & 1.031 & 0.838 & & 0.768 & 1.385 \\
\hline Earned college credit in high school & 0.087 & 0.187 & 1.091 & 0.643 & & 0.756 & 1.574 \\
\hline Number of colleges applied to & -0.017 & 0.032 & 0.983 & 0.590 & & 0.923 & 1.047 \\
\hline Institutional aspects considered index & 0.096 & 0.066 & 1.101 & 0.144 & & 0.968 & 1.252 \\
\hline Siblings in college & 0.215 & 0.153 & 1.240 & 0.159 & & 0.919 & 1.673 \\
\hline \multicolumn{8}{|l|}{ College experiences } \\
\hline Academic integration index & 0.008 & 0.002 & 1.008 & 0.000 & $* * *$ & 1.004 & 1.011 \\
\hline Price of attendance 2003-2004 & 0.216 & 0.060 & 1.241 & 0.000 & $* * *$ & 1.104 & 1.395 \\
\hline Social integration index & 0.007 & 0.002 & 1.007 & 0.000 & $* * *$ & 1.004 & 1.010 \\
\hline Started at a 4-year institution & -0.350 & 0.220 & 0.704 & 0.112 & & 0.457 & 1.086 \\
\hline
\end{tabular}


Continuing generation students model. Table 13 shows the regression results for the model for continuing generation students. Eleven of the 16 variables were significant predictors of bachelor's degree completion for continuing generation including gender, race, the risk factors index, highest math course taken in high school, high school grade point average, the institutional aspects index, a sibling attending college before the student, the academic and social integration indices, the price of attendance, and starting at a 4-year institution. As indicated by the odds ratio of 0.64 as shown in Table 13, being male decreased the odds of completing a degree by approximately $36 \%$. Four variables had a significant negative effect on the probability of completing a degree. Increases in the risk factors index and taking a math course lower than calculus or not taking a math course in high school decreased the odds of completing a degree. Students who indicated their race/ethnicity as Hispanic or Latino were less likely to complete degrees than students who indicated their race/ethnicity as White. Students starting at a 4-year institution were less likely to complete a degree than students who started at a 2-year institution though this finding should be interpreted with caution because the sizes of this variable's two groups were unequal. As mentioned previously approximately ten percent of the sample started at a 2 -year institution, while $90 \%$ started a 4-year institution. Additionally, it is important to note only students who started at a 2year institution and successfully transferred to a 4-year institution are included, not all students who started at a 2-year institution. Thus, these students may be more likely to complete their degrees within the time limit of six years because by the time they attend a 4-year institution, they have their general courses completed and can focus on major courses. 
Six of the significant predictors including two college knowledge variables positively impacted the probability of completing a degree for continuing generation students. As with the other two student groups, for continuing generation students, increases in high school grade point averages and in scores on the academic and social integration indices increased the odds of graduating with a degree. As was the case for first generation students whose parents have some college experience, the price of attendance was a significant predictor for continuing generation students. As the out-ofpocket cost increased, students were more likely to complete their degrees. As mentioned previously, this result should be interpreted with caution because it is quite possible this variable is capturing effects other than the out-of-pocket cost, including the effect of parental income, institution type, and the lower cost of attending a 2-year institution for students who started at a 2-year institution.

The two variables related to level of college knowledge possessed by the student that were significant predictors for continuing generation students are the institutional aspects considered index and a sibling attending college before the student. As the number of institutional aspects considered by the student increased, the odds of completing a degree increased for continuing generation students. Continuing generation students who had a sibling attend college before them were 1.4 times more likely to complete their degree than students who did not have a sibling attend college before them. 
Table 13

Binomial Logistic Regression Results, Individual Predictors of Completing a Bachelor's Degree in Six Years for Continuing Generation Students

\begin{tabular}{|c|c|c|c|c|c|c|c|}
\hline \multirow[b]{2}{*}{ Variable } & \multirow[b]{2}{*}{$B$} & \multirow[b]{2}{*}{$\mathrm{SE}$} & \multirow{2}{*}{$\begin{array}{l}\text { Odds } \\
\text { Ratio }\end{array}$} & \multirow[b]{2}{*}{ Sig. } & & \multicolumn{2}{|c|}{$\begin{array}{l}95 \% \text { Confidence } \\
\text { Interval for } \\
\text { Odds Ratio }\end{array}$} \\
\hline & & & & & & Upper & Lower \\
\hline \multicolumn{8}{|l|}{ Student Characteristics } \\
\hline Gender: Male & -0.439 & 0.099 & 0.644 & 0.000 & $* * *$ & 0.530 & 0.783 \\
\hline Asian (White) & -0.208 & 0.205 & 0.812 & 0.311 & & 0.543 & 1.215 \\
\hline Black or African American (White) & -0.216 & 0.215 & 0.806 & 0.316 & & 0.528 & 1.230 \\
\hline Hispanic or Latino (White) & -0.492 & 0.213 & 0.611 & 0.021 & * & 0.402 & 0.928 \\
\hline Other race/ethnicity (White) & -0.242 & 0.179 & 0.785 & 0.177 & & 0.552 & 1.115 \\
\hline Risk index & -0.472 & 0.107 & 0.624 & 0.000 & $* * *$ & 0.506 & 0.770 \\
\hline \multicolumn{8}{|l|}{ Pre-College Academic Preparation } \\
\hline Pre-calculus (Calculus) & -0.274 & 0.126 & 0.760 & 0.030 & * & 0.594 & 0.973 \\
\hline Trigonometry/algebra II (Calculus) & -0.487 & 0.133 & 0.614 & 0.000 & $* * *$ & 0.473 & 0.798 \\
\hline Algebra II (Calculus) & -0.796 & 0.147 & 0.451 & 0.000 & $* * *$ & 0.338 & 0.601 \\
\hline None (Calculus) & -0.654 & 0.264 & 0.520 & 0.014 & * & 0.310 & 0.874 \\
\hline High school grade point average & 0.365 & 0.055 & 1.440 & 0.000 & *** & 1.292 & 1.605 \\
\hline Took a rigorous high school curriculum & 0.175 & 0.106 & 1.191 & 0.099 & & 0.968 & 1.465 \\
\hline \multicolumn{8}{|l|}{ Cultural Capital/College Knowledge } \\
\hline Consulted list of colleges & 0.037 & 0.096 & 1.038 & 0.697 & & 0.860 & 1.254 \\
\hline Considered graduation rate & 0.037 & 0.096 & 1.038 & 0.698 & & 0.860 & 1.252 \\
\hline Earned college credit in high school & -0.021 & 0.102 & 0.979 & 0.835 & & 0.802 & 1.195 \\
\hline Number of colleges applied to & 0.040 & 0.023 & 1.041 & 0.082 & & 0.995 & 1.090 \\
\hline Institutional aspects considered index & 0.124 & 0.047 & 1.132 & 0.009 & ** & 1.032 & 1.243 \\
\hline Sibling in college & 0.294 & 0.094 & 1.342 & 0.002 & ** & 1.117 & 1.613 \\
\hline \multicolumn{8}{|l|}{ College Experiences } \\
\hline Academic integration index & 0.006 & 0.001 & 1.006 & 0.000 & $* * *$ & 1.003 & 1.008 \\
\hline Price of attendance 2003-2004 & 0.142 & 0.030 & 1.153 & 0.000 & $* * *$ & 1.087 & 1.223 \\
\hline Social integration & 0.006 & 0.001 & 1.006 & 0.000 & $* * *$ & 1.004 & 1.009 \\
\hline Started at a 4-year institution & -0.397 & 0.148 & 0.672 & 0.008 & $* *$ & 0.502 & 0.900 \\
\hline
\end{tabular}




\section{CHAPTER FIVE}

\section{DISCUSSION}

\section{Overview of Purpose of the Study}

The purpose of this study was to examine first generation student degree completion using data from the 2004-2009 Beginning Postsecondary Students Survey (BPS:04/09), which tracked approximately 16,800 students who entered college in 2003 for six years. First, the study examined the relationship between first generation status and bachelor's degree completion after controlling for student background characteristics and other college experience variables identified as salient predictors in existing degree completion models. Second, the study examined whether the predictors of bachelor's degree completion vary for three student groups: first generation students whose parents have no college experience, first generation students whose parents have some college experience, and continuing generation students.

\section{Summary of Methods Used in the Study}

Logistic regression models were created to address both of the research questions. The sample for this study was students who started at a 4-year institution or started at a 2year institution and enrolled in a 4-year institution by 2006 , or three years after entering postsecondary education. The dependent variable for all models was graduation status or bachelor's degree attainment six years after enrolling in college. The following four categories of independent variables were entered into the models: 1) student demographics, 2) pre-college academic performance and preparation variables, 3) college knowledge/cultural capital variables, and 4) college experience variables. 
The first set of logistic regression models were created to determine whether first generation status, in both its original definition and its updated definition as conceptualized in previous research studies, predicted bachelor's degree attainment within six years from enrolling in college after controlling for student entering characteristics, pre-college academic performance and preparation, cultural capital, and college experience factors. To create the samples for the three models used to answer the second research question, I divided the overall study sample of students who started at a 4-year institution or started at a 2-year institution and enrolled in a 4-year institution by 2006 further using first generation status. The three models were used to determine whether the factors predicting degree completion varied for three groups of students. Two groups were first generation students: first generation students whose parents have no college experience and first generation students whose parents have some college experience. The third group was continuing generation students.

\section{Summary and Discussion of Findings}

\section{Research Question 1}

First generation status and degree completion. This study's findings suggest being a first generation student is negatively associated with bachelor's degree completion in six years, even after controlling for student demographics, pre-college academic preparation, and college experience factors. First generation status, in its two conceptualizations, was a significant predictor of bachelor's degree completion. When first generation students, as defined as those students whose parents have no college experience, were compared to continuing generation students, first generation status was a significant predictor of bachelor's degree completion. First generation students whose 
parents have no college experience were less likely to graduate than continuing generation students. When first generation status was comprised of three student groups, students whose parents have no college experience, students whose parents have some college experience and continuing generation students, first generation status continued to be a significant predictor of degree completion. Both first generation students whose parents have no college experience and first generation students whose parents have some college experience were less likely to graduate than continuing generation students.

Defining first generation status. In the original conceptualization of first generation status in higher education research, students whose parents have some college experience are grouped with continuing generation students and first generation students are defined as only those students whose parents did not attend any college. However, this study provides evidence to indicate first generation students whose parents have some college experience may need to be studied as a group separate from continuing generation students. First generation students whose parents have some college experience differ descriptively from continuing generation students on a variety of characteristics related to degree completion and more importantly, the significant factors of degree completion for this group of students vary from those for first generation students whose parents have no college experience and continuing generation students.

Regarding factors related to the student's level of college knowledge, lower percentages of students whose parents have some college experience earned college credit in high school, consulted a college guide when applying to colleges, and considered the institution's graduation rate than did continuing generation students. Students whose parents have some college experience had lower average scores on the 
academic and social integration indices than continuing generation students, suggesting that these students have lower levels of academic and social integration in college. While the degree completion models included four categories of existing salient factors of degree completion, only eight of the sixteen variables in the models for degree completion were significant predictors for first generation students whose parents have some college experience, while eleven of the variables were significant for first generation students whose parents have no college experience and continuing generation students. This finding may indicate there are potential factors associated with degree completion for first generation students whose parents have some college that have not yet been identified in previous research. None of the factors related to the student's level of college knowledge predicted degree completion for first generation students whose parents have some college experience though three of the college knowledge factors predicted degree completion for first generation students whose parents have no college experience. This finding may indicate the level of college knowledge possessed at the time of enrollment matters for first generation students whose parents have no college experience, but may not be as important for first generation students whose parents have some college experience.

\section{Research Question 2}

Predictors of degree completion by first generation status. The results of this study suggest there is value in examining degree completion for different groups of students by first generation status. The variables significant in predicting bachelor's degree completion varied for first generation students whose parents have no college experience, first generation students whose parents have some college experience and 
continuing generation students. Consulting a college guide with a list of rankings was a significant predictor of degree completion for first generation students whose parents have no college experience, but was not significant in the models for the other two groups of students. The two groups of first generation students shared one significant predictor. Taking a rigorous high school curriculum significantly increased the likelihood of degree completion for first generation students whose parents have no college experience and first generation students whose parents have some college experience, but was not a significant predictor for continuing generation students. Two of the college knowledge variables, whether a sibling attended college before the student and the institutional aspects considered index, as well as gender and starting at a 4-year institution, were significant predictors for first generation students whose parents have no college experience and continuing generation students, but did not predict degree completion for students whose parents have some college experience. Price of attendance, or the out-of pocket expense for tuition, books, and living expenses, incurred by the student, and race/ethnicity predicted degree completion for students whose parents have some college experience and continuing generation students, but were not significant factors for first generation students whose parents have no college experience.

Impact of college knowledge on degree completion. Previous research has shown that several types of knowledge about the college experience are associated with attaining success within the higher education system such as knowing how to navigate the bureaucratic systems of a college including registering for classes and financial aid, knowing how to interact and develop relationships with faculty members, school personnel and peers, and knowledge on how to overcome barriers to success encountered 
during college (Stanton-Salazar, 1997). For this study, in order to test the effect on degree completion of the student's level of knowledge about the college-going experience before enrolling in college, several factors were hypothesized to represent college knowledge including whether the student took courses at a college or university in high school, if the student consulted a published list of college rankings and the institution's graduation rate before selecting a college, if the student had a sibling attend college before him or her, and whether the student considered various institutional aspects including whether the institution has their program of study, the location, the cost, and the reputation in their decision to attend the institution.

Taking courses at a college or university in high school suggests the student would have knowledge of the college experience, including an understanding of what the coursework is like and the requirements that must be met in order to succeed in college. Consulting a college guide with a list of college rankings and considering the institution's graduation rate may be viewed as proxies for whether a student received assistance applying to college from someone in their social network including parents, peers, or a counselor or official in high school because counseling offices typically provide these types of information. Whether the student factored various institutional aspects in their decision to attend the university suggests the student engaged in a formalized college selection process by considering multiple aspects of the institution. In particular, the factors included in the institutional aspects index constructed for this study-- the program of study, the cost, the reputation, and the location of the institution -- can be viewed as factors that would assist the student in determining if the institution is a good fit. This study hypothesized if a student had a sibling who attended college before him or her, the 
student may have knowledge about the college experience that could facilitate success. Finally, the number of colleges the student applied to was tested in the model as a proxy for the student's knowledge of the college application process. It was hypothesized that students who applied to more than one college may know the importance of expanding their available options in case they are not accepted to their chosen college.

The results showed that factors related to a student's level of college knowledge before enrolling in college increased the likelihood of degree completion for first generation students whose parents have no college experience and continuing generation students. Consulting a college guide with a list of college rankings, a proxy for whether a student received assistance on applying to college from parents, peers, or a counselor or official in high school, was a significant predictor of degree completion for first generation students whose parents have no college experience. First generation students whose parents have no college experience who consulted a college guide were almost one and a half times more likely to complete their bachelor's degree. An index comprised of the number of institutional aspects considered by the student in his or her decision to attend an institution was a significant predictor of degree completion for first generation students whose parents have no college experience and continuing generation students. Increases in the number of institutional aspects that were factored into the student's decision to attend the institution increased the likelihood of completing a degree, suggesting a well-informed and formalized college selection process plays a role in whether a student completes their degree. This finding may suggest students who consider the various aspects of the institution that will assist them in deciding if the university or college is a good fit with their interests and goals during the college 
selection process are more likely to complete a degree. Finally, having a sibling in college increased the likelihood of graduating for first generation students whose parents have no college experience and continuing generation students. First generation students whose parents have no college experience who had a sibling attend college before them were 1.4 times as likely to complete their degrees while continuing generation students who had a sibling in college were 1.3 times as likely to complete their degrees.

\section{Comparison of Results to Previous Research}

\section{Defining First Generation Students}

Much of the previous research on first generation students has been based on a dichotomous view of first generation status where first generation students are those students whose parents did not attend college and continuing generation students are students whose parents are at all other education levels. While recent research has begun to separate students whose parents have some college experience from continuing generation students (Nuñez \& Cuccaro-Alamin, 1998; Horn \& Nuñez, 2000; Warburton, Bugarin \& Nuñez, 2001; Chen \& Carroll, 2005) the intention of the researchers in doing so was not to examine the students as a unique group, but to allow for a more accurate comparison of traditional first generation students, those students whose parents have no college experience, with continuing generation students. This study's results add to the literature in that they suggest first generation students whose parents have some college experience may need be examined as a unique group in terms of degree completion because the significant factors of degree completion were different for first generation students whose parents have some college experience as compared to the factors that 
were significant predictors of degree completion for first generation students whose parents have no college experience and continuing generation students.

This study's finding that first generation students are significantly less likely to graduate than continuing generation students is consistent with the relationship between first generation status and persistence and degree attainment identified in the majority of the literature (Nuñez \& Cuccaro-Alamin, 1998; Warburton, Bugarin, \& Nuñez, 2001; Ishitani, 2003; Chen \& Carroll, 2005). In a study conducted by Nuñez and CuccaroAlamin (1998), first generation status had a negative effect on degree attainment after controlling for socioeconomic status, institution type, and attendance status while Warburton, Bugarin, and Nuñez (2001) came to a similar conclusion after controlling for pre-college academic preparation; suggesting that first generation status has an effect independent of other related factors. The models in this study similarly controlled for some of the factors that are related to first generation status, such as the number of risk factors a student has and their level of pre-college academic preparation and found first generation status still to be a significant predictor of degree completion. However, other studies have found the effect of first generation status was insignificant once institutional characteristics and other variables were added to the models (Franke, 2012).

\section{Predictors of Degree Completion for First and Continuing Generation Students}

Nearly all of the variables identified in previous research as significant predictors of degree completion were significant for each of the groups of students examined in this study, although there were a few notable differences. In terms of gender, previous studies have shown that on average, women have a higher rate of degree completion (Nora, Barlow, \& Crisp, 2005; Horn, 2006; Bailey \& Dynarski, 2011). In this study, for 
two of the groups, male students were less likely to graduate than female students, which is the same relationship between gender and degree completion found in the literature. However, this study's findings did not entirely conform to previous research because gender was not a significant predictor for first generation students whose parents have some college experience. This study's results regarding race/ethnicity contrasted with previous research. Race/ethnicity was a significant predictor for two of the student groups, even though race/ethnicity has not generally proved to be a determinant of degree completion in the literature (DesJardins, Kim \& Rzonca, 2002; Lee, 2010; Adelman, 2004). Desjardins, Alburg, and McCall (2006) posit the explanation that differences in educational outcomes attributed to race/ethnicity may stem from differences in family income and high school performance. While this study controlled for high school academic performance factors and still found race/ethnicity to be a significant predictor for two of the groups, family income was not included as a control variable due to its potential relationship with the price of attendance variable. The price of attendance was calculated by subtracting all financial aid from the total cost for the 2003-2004 academic year. Family income is used to by colleges and universities to determine the amount of financial aid a student receives and thus, is related to the price of attendance variable.

Consistent with students conducted by Adelman (1999) and Astin and Lee (2005), high school GPA and highest level of mathematics taken in high school were positively associated with degree completion for all three student groups. Adelman's (2004) academic resources composite that takes into account the rigor of the high school curriculum was the most salient predictor in his model. In this study, while taking a rigorous high school curriculum was a significant predictor for two of the student groups, 
it did not significantly predict degree completion for students whose parents have some college experience.

The results from this study in terms of the relationship between college experiences and completing a degree are generally consistent with the literature. The results suggest levels of increased academic and social integration have a positive impact on completing a bachelor's degree support, which is in line with findings in other studies, such as those conducted by Tinto (1975) and Astin (1975). Additionally, this study found that social integration was a significant predictor of degree completion for both first generation student groups, despite the fact that it has been suggested social integration has less of an influence on nontraditional students such as first generation students (Bean \& Metzner, 1985).

In this study, the price of attendance variable, that represented the out-of-pocket cost to the student, had a significant positive relationship with degree completion for students whose parents have some college experience and continuing generation students. As the out-of-pocket cost to the student increased, the likelihood of degree completion increased or conversely as the amount of loans and grant aid increased, the likelihood of graduation decreased. This finding, which is generally inconsistent with previous research, should be interpreted with caution because it is quite possible this variable is capturing several other effects. First, the price of attendance variable could be reflecting the effect of parental income. The amount of financial aid received by a student is related to family income, as students from low-income families tend to receive higher amounts of aid and the price of attendance variable was calculated by subtracting all financial aid from the cost of tuition, books, and living expenses. Students from low-income families, 
or those students who would have lower out-of-pocket costs, tend to be less likely to complete degrees (Titus, 2006; Adelman, 2004; Bailey \& Dynarski, 2011; Cabrera, Burkum, \& La Nasa, 2005). Second, the price of attendance variable may be capturing some of the effect of institution type. Higher out-of-pocket costs may be related to the type of institution attended by the student because the cost of attending private institutions tends to be higher than the cost of attending public or for-profit institutions. Students who attend private institutions, or those students who would have higher out-ofpocket costs, tend to be more likely to complete degrees. For example, in a study conducted by the National Center for Education Statistics, among students seeking degrees at 4-year institutions in fall 2005, the 6-year graduation rate for students at a private nonprofit institution was $65 \%$, compared to a graduation rate of $57 \%$ for students at public institutions, and $42 \%$ for students at private for-profit institutions (Aud, Wilkinson-Flicker, Kristapovich, Rathbun, Wang, \& Zhang, 2013). Third, the price of attendance variable represents the out-of-pocket cost of the 2-year institution attended by students who started at 2-year institution, a cost that is perhaps lower than the cost of the 4-year institution attended by these students. Finally, the price of attendance variable was only collected at one point in time and does not reflect changes in cost that may occur over a student's college career.

The positive relationship between the out-of-pocket cost to the student and degree completion found in this study is inconsistent with previous studies when income was included simultaneously with financial aid variables in the degree completion model and when changes in financial aid over time were accounted for. For example, Ishitani and Desjardins (2002) included a measure of parental or personal income in their model along 
with financial aid variables and found the risk of departure for students who received financial aid was significantly lower than students who received no-aid in the first, second, third, and fourth years of enrollment in college. Thus, this finding should not be interpreted in a manner that would result in decisions to decrease the amounts of need or merit based aid given to students because many first generation students rely on financial aid to access higher education. The finding may be able to be interpreted as students who pay more for college out of pocket, thus not accruing a large amount of loan debt, are more likely to graduate, which is in line with previous research that indicates first generation students are more likely to drop out than continuing generation students when they have large amounts of loan debt (Somers, Woodhouse, \& Cofer, 2000).

While no other studies have conceptualized the student's level of college knowledge before enrolling in precisely the same manner as in this study, this study's finding that a student's level of knowledge about the college going experience may play a role on degree completion is consistent with previous literature in this area. Variables representing college knowledge have been studied in depth in relationship to a student's likelihood of enrollment in college (McDonough, 1997; Horn \& Nuñez, 2000), but only a handful of existing studies indicate having college knowledge before attending college relates positively to degree completion. For example, a 1985 study conducted by DiMaggio and Mohr used knowledge of high society arts and culture as a proxy for knowledge of the value of college and the college experience and found the knowledge was positively associated with degree completion. In this study, consulting a college guide with a list of college rankings, a proxy for whether a student received assistance on applying to college from someone in their social network including a counselor or official 
in high school, parents, or peers, was a significant predictor of degree completion for first generation students whose parents have no college experience. Additionally, increases in the number of institutional aspects that were factored into the student's decision to attend the institution increased the likelihood of completing a degree for first generation students whose parents have no college experience and continuing generation students, suggesting a well-informed and formalized college selection process plays a role in whether a student completes their degree. This finding fits into the existing literature as there is evidence students who engage in extensive and diverse information gathering during the college selection process are more satisfied with their college choice and are more likely to find a good college match (Hamrick \& Hossler, 1996). Finding a college that matches well with the student's academic and social expectations and interests has been shown to be a significant factor in completing college (Braxton, Vesper, \& Hossler, 1995). Finally, the study's results indicated having a sibling in college was positively associated with degree completion. A student having a sibling attend college before him or her could represent a type of social support being provided to the student. Previous studies have indicated social support from family members, friends, or siblings plays a role in retention (Endecavage, 2000; Ishitani, 2005).

\section{Implications for Colleges and Universities}

For universities to design degree completion initiatives tailored to first generation students, it is first important to understand which students should be classified as first generation students. For example, when universities and colleges define first generation students as those whose parents have no college experience while planning degree completion initiatives, students whose parents have some college experience are grouped 
with continuing generation students and would not receive first generation student interventions and programs. This study indicates first generation students whose parents have some college experience had descriptively different characteristics than continuing generation students, indicating students whose parents have some college experience may need to be treated as a separate group in terms of their needs and paths toward degree completion.

When designing degree completion initiatives, colleges and universities should be cautious about assuming students whose parents have some college experience are similar to continuing generation students because the significant predictors of degree completion for these students differed from those for continuing generation students. Additionally, colleges and universities may not be able to assume the interventions that work for first generations students will have a similar effect on students whose parents have some college experience. The results of this study indicate some of the factors that predicted degree completion for students whose parents have no college experience did not have the same impact on first generation students whose parents have some college experience. Three variables related to college knowledge, consulting a published list of college rankings, the number of institutional aspects considered, and having a sibling attend college first were significant for first generation students whose parents had no college experience, but did not predict degree completion for students whose parents have some college experience. Thus, an initiative designed with the intent to increase the student's knowledge about the college experience including how to choose a program of study or how to register for courses may not have an impact on degree completion for students whose parents have some college experience. 


\section{First Generation Degree Completion Initiatives}

Provide critical information. The results of this study provide information to assist colleges and universities in determining which elements to focus on when tailoring degree completion initiatives for first generation students. The results suggest first generation students are more likely to graduate when they receive information about the college experience that helps them to succeed. First, the study found students whose parents have no college experience are more likely to complete their degree when they consult a college guide. Consulting a college guide with a list of rankings can be viewed as a proxy for the level of assistance students receive on the college selection process from parents, peers, or high school guidance counselors. Important information typically provided by school counselors that can help first generation students succeed in college includes detailed information about different colleges, how to obtain scholarships, aid, or financing for college and information about course selection in high school that will best prepare the students for college (Reid \& Moore, 2008). It may be that students who possess these types of knowledge at the beginning of their college career are more likely to graduate because they have detailed information about what the college can offer to them that is necessary to make informed choices during college, maximize the benefits they receive from college, and achieve success. Having knowledge on financial aid options may allow students to be in a better position to address challenges that arise regarding paying for college.

Taking a rigorous high school curriculum was a significant predictor for both groups of first generation students. Although taking a rigorous high school curriculum serves as an indicator a student is academically prepared to succeed in college, for first 
generation students taking rigorous high school courses could potentially be related to college knowledge in that students who take rigorous courses in high school have a better idea of what their courses are going to be like in college. For example, interviews conducted by Richardson and Skinner (1992) with college graduates revealed continuing generation students felt confident that they could do well in their college courses because they were similar to the courses they took in high school, while first generation students mentioned having an unfamiliarity with the courses that lowered their confidence they could succeed at the college level. The importance of academic validation during first generation students' transition to college was a theme that emerged from focus group interviews conducted by Terenzini and colleagues (1994). Particularly, first generation students expressed their need to be reassured that they will succeed in college, they will be able to do college level work, and that they deserve the respect and time from faculty members afforded to other students.

Finally, this study found first generation students whose parents have no college experience were more likely to graduate when they had a sibling who attended college before them. Having a sibling who has college experience may provide the student with access to insider information about the college experience including how to select courses or professors or how to recover from a setback such as failing a course that can facilitate success. For example, research by Pascarella, Pierson, Wolniak, and Terenzini (2004) suggests if a first generation student interacts with individuals who have a better understanding of the behaviors needed to do well academically in college, they can gain cultural capital that can help them succeed. 
If, as the results of this study suggest, first generation students whose parents have no college experience are more likely to graduate when they possess certain types of knowledge about the college experience, colleges and universities could tailor degree completion initiatives to first generation student needs by designing them to provide the critical information about college necessary for success. Potential initiatives to increase first generation students' knowledge of the college experience could be implemented at the time the student applies and during the first year to set the student up for success. For example, admissions counselors could set aside time to cover certain topics such as scholarships and financial aid in more depth than during the average college tour. After identifying a relationship between how well expectations about certain aspects of college were met once the students started attending college and their intent to return, Braxton, Vesper, and Hossler (1995) conclude colleges need to accurately portray characteristics about the college including class size, the satisfaction of current students, the availability of athletic and other campus activities, and what percentage of students attend graduate schools and which graduate schools they attend, to prospective students.

Support services first generation students receive after enrolling in college could be modified to provide the information to help first generation students succeed academically. For example, the content in tutoring programs could be tailored in order for tutors to not only teach students how to master the content in the course, but additionally to provide time management and strategies for studying that first generation students may not have learned previously. Advising sessions provided by faculty members could be designed in connection with the university's career services department to emphasize how the student's program of study fits in with future goals and 
career plans and how coursework can provide knowledge that can be used to obtain and succeed in internships as well as be used in their future careers.

When tailoring initiatives to provide the information necessary for first generation students to succeed, colleges and universities may need to pay particular attention on how the information is delivered to the students through the programs and interventions. Interviews conducted by Torres, Reiser, LePeau, Davis, \& Ruder (2006) revealed first generation students did not view advisors as authority figures who could assist them in finding information they needed and help them to solve problems related to academics and first generation students sought advice from peers with similar backgrounds. Additionally, Inkelas, Daver, Vogt, and Leonard (2007) found structured faculty interaction and residence hall programing had more impact on first generation student success than informal peer groups. To ensure the information is being provided to first generation students, advisors could proactively seek out students instead of waiting for the students to make an appointment. Tutoring and mentoring programs could focus recruitment efforts on finding successful first generation students who faced similar challenges as the students receiving the services.

Determine institutional fit. The results of this study suggest engaging in an extensive college selection process in which multiple institutional aspects are considered in the decision to attend an institution relates positively to graduation. In this study, the institutional aspects considered index was a significant predictor of graduation for two of the student groups, first generation students whose parents have no college experience and continuing generation students. The likelihood of degree completion increased as the number of aspects factored into the student's decision to attend an institution increased, 
suggesting students who consider various aspects of the institution that could assist them in deciding if the university or college is a good fit with their interests and goals during the college selection process are more likely to complete a degree. The institutional aspects that made up the index: program of study, reputation, cost, and location, can be viewed as some of the factors a student uses to determine whether the institution is a good fit with their interests and goals.

Because they are less likely to receive assistance from their parents and their high school counselors, colleges and universities could adopt initiatives to help ensure first generation students who apply to their institution are engaging in a well-informed selection process and are considering different aspects about the institution. The initiatives could involve providing prospective students with information that allows them to determine if the institution is a good fit with their interests and goals because finding a college that matches a student's academic and social interests has been shown to be a significant factor in college success (Braxton, Vesper, \& Hossler, 1995). In this study, students were more likely to graduate if they considered whether the institution has their program of study as well as the institution's reputation, affordability, and location. While most institutions provide prospective students with a list of programs offered by the university, many students, particularly first generation students, may not know how to make the connection between their future personal and career goals and selecting a program of study. For example, Arbona (1994) found first generation students are more likely than continuing generation students to lack knowledge of how to connect their career goals with their educational decisions. Institutions could implement an initiative that provides prospective students with a personalized session with an admissions 
counselor in which a student discusses how his or her interests and goals match the programs of study at the institution. Considering the institution's reputation could mean the student has knowledge about where the college stands relative to other institutions. Institutions could provide prospective students with information about the particular programs and research the college is well-known for and which fields the institution's graduates seek careers in after completing their degree. Previous research suggested first generation students tend to be misinformed about college costs and financial aid (Ikenberry \& Hartle, 2000), making it difficult for them to accurately consider the affordability of the institution in their decision to attend. Institutions could provide detailed information about the process of applying for and receiving financial aid and the eligibility requirements for different types of financial aid to prospective students. Mechanisms designed to provide transparency in college costs such as college scorecards could help prospective students make well-informed decisions about which college they attend and improve degree completion rates. Finally, institutions could encourage prospective students to consider what role the school's location plays in their decision to attend by drawing attention to the benefits and costs of attending an institution close to or far away from home. Overall, the positive relationship between the number of institutional aspects a student considers during the college selection process and degree completion found in this study indicates it may be important for institutions to develop their admissions programs and initiatives to provide information and a process that allows prospective students to make a well-informed decision about attending the institution. 


\section{Limitations}

Secondary data analysis, the primary analytical strategy proposed for this study, has several limitations. First, any analyses conducted with data collected through a nonexperimental research design cannot show causal relationships, only correlations. Thus, this study can only infer how particular factors are related to degree completion because cause and effect conclusions cannot be made. Second, the analysis will be limited by the availability of variables in the dataset. Due to the fact data collection is bound by the constraints of finite resources and time, no dataset is going to contain every possible predictor of first generation student success. In addition, the researchers conducting the Beginning Postsecondary Students Longitudinal Study made decisions about which information to collect based on the specific purposes and goals of the study. As a result it is likely the dataset is missing possible salient factors in first generation student success. For example, though the BPS:04/09 study collected information about many aspects of students' college experiences including indicators of social and academic integration, enrollment and course-taking patterns, and majors, the dataset lacks information about other facets of the college experience found to be significant in predicting educational outcomes such as receiving encouragement from friends to remain in college (Terenzini, et al., 1996) and perceptions about faculty members' concern toward students and teaching (Nora \& Cabrera, 1996).

There are qualitative aspects of the respondents' college experience with the potential to influence degree completion that cannot be represented by data collected in a survey. For example, previous research indicates the success of first generation students is influenced by a variety of cultural factors including lack of family support (York- 
Anderson \& Bowman, 1991) and challenges occurring during the transition to college including experiencing a college culture different from their family culture and breaking family tradition by being the first to attend college (Terenzini et. al., 1996). An in-depth look at the personal experiences of first generation students that addresses how they interact with their family and community when they return home after attending college cannot be captured in this study's quantitative analysis of survey data. Taken together, the extent to which these missing factors are correlated with the variables included in the analysis determine the amount of bias introduced into the affected estimated coefficients; however, since there is no statistical way to control for this type of specification error the potential existence of the problem can merely be pointed out and unfortunately, not statistically addressed.

A limitation with the dataset is the dependent variables in the logistic regression models for part two reflect whether the student graduated with a bachelor's degree in six years. Students who completed their bachelor's degrees more than six years after their initial enrollment will not be reflected accurately in the dependent variable because data on degree attainment status was only collected at the six year mark. An analysis of quantitative data requires the categorization of respondents into meaningful groups. Categorization can result in the omission of differences between the respondents in the same group; differences which may prove to affect the findings of the analysis. For example, while two students could be categorized as first generation students because neither parent has attended college, the individual experience of the two students may vary greatly. One student's parents might stress the importance of obtaining a degree because the parents did not have the opportunity to attend, while the other student's 
parents may downplay the value of higher education because they were able to succeed without college degrees. Although both students would be categorized as first generation students, their unique experiences differ widely and nuances such as these will not be represented by the data.

\section{Implications for Future Research}

The results indicate the predictors of degree completion vary for first and continuing generation students, suggesting new insights may be gained by examining degree completion for other groups of at-risk students such as military or students who begin college after the age of 24. As initiatives such as the Yellow Ribbon Program and the Post-9/11 GI Bill have increased the number of military students attending college, the government has begun to focus their attention on the graduation rates of veteran and military students (Sander, 2012) and institutions are now required to collect more information about military students. Institutions could use this information to build models to determine the unique factors of persistence and degree completion for military students. In this study, nontraditional students with respect to age were excluded from the analysis because information for many of the pre-college academic performance variables was collected only for students under the age of 24 . Future analyses could be conducted to study students who begin college after the age of 24 in more depth to identify their unique needs in terms of degree completion.

A second avenue for future research is to continue to study students whose parents have some college experience separately from continuing generation students because the significant factors of degree completion differed for this group of students. Previous studies have separated students whose parents have some college experience 
from first and continuing generation students to allow for a more accurate comparison of first generation students with continuing generation students (Nuñez \& Cuccaro-Alamin, 1998; Horn \& Nuñez, 2000; Warburton, Bugarin \& Nuñez, 2001; Chen \& Carroll, 2005) or to demonstrate students whose parents have some college experience have an advantage over first generation students in several areas related to degree completion (Pascarella, Pierson, Wolniak, \& Terenzini, 2004), but did not examine this group in depth to determine whether this group has its own needs in terms of degree completion. Further research on the factors associated with degree completion for students whose parents have some college experience is warranted because in this study, none of the college knowledge variables including those that were significant predictors for first generation students whose parents have no college experience, predicted degree completion for students whose parents have some college experience.

Finally, this study's findings indicate a student's level of knowledge about the college going experience may play an important role in degree completion for first generation students whose parents have no college experience. Researchers conducting future studies using nationally representative datasets similar to the BPS:04/09 dataset could consider including factors related to college knowledge including the level of assistance students receive when selecting a college as well as the process they engage in to decide if the institution is a good fit in degree completion models. Colleges and universities conducting retention research at the institutional level could consider how to collect information about their students' level of knowledge about the college experience at the time of enrollment and test the effect of these variables in their research on persistence and degree completion. 


\section{References}

Adelman, C. (1999). Answers in the tool box: Academic intensity, attendance patterns, and bachelor's degree attainment. Washington, DC: U.S. Department of Education.

Adelman, C. (2004). Answers in the toolbox: Academic intensity, attendance patterns, and bachelor's degree attainment. Washington, DC: U.S. Department of Education.

An, C.B., Haveman, R., \& Wolfe, B. (1993). Teen out-of-wedlock births and welfare receipt: The role of childhood events and economic circumstances. The Review of Economics and Statistics, 195-208.

Arbona, C. (1994). First generation college students: A review of needs and effective interventions. Houston, TX: Decision Information Resources.

Astin, A.W. (1975). Preventing students from dropping out. San Francisco: Jossey-Bass.

Astin, A.W. (1984). Student involvement: A developmental theory for higher education. Journal of College Student Personnel, 25(4), 297-308.

Astin, A.W. (2005). Making sense out of degree completion rates. Journal of College Student Retention, 7(1-2), 5-17.

Astin, A.W., \& Lee, J. (2003). How risky are one-shot cross-sectional assessments of undergraduate students? Research in Higher Education, 44(6), 657-672.

Astin, A.W., \& Oseguera, L. (2005). Degree attainment rates at American colleges and universities (Rev. ed.). Los Angeles: Higher Education Research Institute, UCLA.

Aud, S., Wilkinson-Flicker, S., Kristapovich, P., Rathbun, A., Wang, X., \& Zhang, J. (2013). The Condition of Education 2013 (NCES 2013-037). Washington DC: U.S. Department of Education, National Center for Education Statistics (NCES).

Bailey, M.J. \& S.M. Dynarski (2011, December). Gains and gaps: Changing inequality in U.S. college entry and completion: Working Paper 17633. Cambridge, MA: National Bureau of Economic Research.

Banta, T.W., Rudolph, L.B., Van Dyke, J., \& Fisher, H.S. (1996). Performance funding comes of age in Tennessee. The Journal of Higher Education, 67(1), 23-45.

Baum, S., \& Ma, J. (2007). Education pays: The benefits of higher education for individuals and society. New York, NY: College Board. 
Baum, S., \& Payea, K. (2004). Education pays: The benefits of higher education for individuals and society. New York, NY: College Board.

Bean, J.P. (1979). Dropouts and turnover: The synthesis and test of a causal model of student attrition. Paper presented at the Annual Meeting of the American Educational Research Association, San Francisco, CA.

Bean, J.P. (1990). Why students leave: Insights from research. In D. Hossler \& J. P. Bean (Eds.), The strategic management of college enrollments (pp. 147-169). San Francisco: Jossey-Bass.

Bean, J.P., \& Metzner, B.S. (1985). A conceptual model of nontraditional undergraduate student attrition. Review of Educational Research, 55(4), 485-540.

Berger, J. B. (2000). Optimizing capital, social reproduction, and undergraduate persistence: A sociological perspective. In J. M. Braxton (Ed.), Reworking the student departure puzzle (pp. 95-126). Nashville, TN: Vanderbilt University Press.

Berkner, L. \& Chavez, L. (1997). Access to postsecondary education for 1992 high school graduates. Washington, DC: National Center for Education Statistics (NCES).

Berkner, L., Cuccaro-Alamin, S., McCormick, A. C., \& Bobbitt, L. G. (1996). Descriptive summary of 1989-90 beginning postsecondary students: Five years later. Washington, DC: National Center for Education Statistics (NCES).

Berkner, L., He, S., \& Cataldi, E.F. (2002). Descriptive summary of 1995-96 beginning postsecondary students: Six years later. Education Statistics Quarterly, 5(1), 6267.

Blose, G. (1999). Modeled retention and graduation rates: Calculating expected retention and graduation rates for multicampus university systems. New Directions for Higher Education, 1999(108), 69-86.

Bourdieu, P. (1986). The forms of capital. In J. G. Richardson (Ed.), Handbook of theory and research for the sociology of education (pp. 241-258). Westport, CT: Greenwood Press, Inc.

Bowen, H.R. (1997). Investment in learning: The individual and social value of American higher education. San Francisco: Jossey Bass, Inc.

Braxton, J.M., Vesper, N., \& Hossler, D. (1995). Expectations for college and student persistence. Research in Higher Education, 36(5), 595-612. 
Bui, V.T. (2002). First-generation college students at a four-year university: Background characteristics, reasons for pursuing higher education, and first-year experiences. College Student Journal, 36(1), 3-11.

Cabrera, A.F., Burkum, K.R., \& La Nasa, S. M. (2005). Pathways to a four-year degree. In A. Seidman (Ed.), College student retention: Formula for student success (pp. 155-214). Westport, CT: Praeger Publishers.

Cabrera, A.F. \& La Nasa, S.M. (2001). On the path to college: Three critical tasks facing America's disadvantaged. Research in Higher Education, 42(2), 119-150.

Cabrera, A.F., La Nasa, S.M., \& Burkum, K.R. (2001). Pathways to a four-year degree: The higher education story of one generation. Report to the Association for Institutional Research. University Park, PA: Center for the Study of Higher Education, The Pennsylvania State University.

Cabrera, A.F., Nora, A., \& Castaneda, M.B. (1992). The role of finances in the persistence process: A structural model. Research in Higher Education, 33(5), 571-593.

Carnevale, A.P., Rose, S., \& Cheah, B. (2011, August). The college payoff: Education, occupation, and lifetime earnings. Washington, DC: Georgetown University, Center on Education and the Workforce.

Carnevale, A.P., Smith, N., \& Strohl, J. (2010, June). Help wanted: Projections of jobs and education requirements through 2018. Washington, DC: Georgetown University, Center on Education and the Workforce.

Chen, X. \& Carroll, C.D. (2005). First generation students in postsecondary education: A look at their college transcripts (NCES 2005-171). Washington DC: National Center for Education Statistics (NCES).

Choy, S. (2000). Low-income students: Who they are and how they pay for their education. Washington, D.C: National Center for Education Statistics (NCES).

Choy, S. (2002). Access \& persistence: Findings from 10 years of longitudinal research on students. Washington, DC: ERIC Clearinghouse on Higher Education.

Choy, S.P., Horn, L.J., Nuñez, A., \& Chen, X. (2000). Transition to college: What helps at-risk students and students whose parents did not attend college? In A.F. Cabrera, \& S.M. La Nasa (Eds.), Understanding the college choice of disadvantaged students (pp. 45-64). San Francisco: Jossey-Bass.

Clinedinst, M. (2004). Investing in America's future: Why student aid pays off for society and individuals. Washington, DC: The Institute for Higher Education Policy. 
Dawson, D. (1991). Family structure and children's health and well-being: Data from the 1988 national health interview survey on children's health. Journal of Marriage and the Family, 53(3), 573-584.

De Vise, D. (2011, September 13). U.S. falls in global ranking of young adults who finish college. The Washington Post, p.A4.

De Walque, D. (2004). Education, information, and smoking decisions: Evidence from smoking histories, 1940-2000 (Working Paper No. 3362). Washington, DC: World Bank.

DesJardins, S.L., Ahlburg, D.A., \& McCall, B.P. (2002). A temporal investigation of factors related to timely degree completion. The Journal of Higher Education, 73(5), 555-581.

DesJardins, S.L., Ahlburg, D.A., \& McCall, B.P. (2006). The effects of interrupted enrollment on graduation from college: Racial, income, and ability differences. Economics of Education Review, 25(6), 575-590.

DesJardins, S.L., Kim, D.O., \& Rzonca, C.S. (2002-2003). A nested analysis of factors affecting bachelor's degree completion. Journal of College Student Retention, $4(4), 407-435$.

DiMaggio, P., \& Mohr, J. (1985). Cultural capital, educational attainment, and marital selection. American Journal of Sociology, 1231-1261.

Dowd, A. C., \& Duggan, M. B. (2001). Computing variances from data with complex sampling designs: a comparison of stata and SPSS. Paper presented at the North American Stata Users Group, Boston, MA.

Durkheim, E. (1951). Suicide. Glencoe: The Free Press.

Endecavage, C. (2000). The role of internal attribution and social support in the college success of African American males. (Doctoral dissertation). Retrieved from ProQuest dissertations \& theses full text. (9955377)

Engle, J., \& Tinto, V. (2008). Moving beyond access: College success for low-income, first generation students. Washington, DC: Pell Institute for the Study of Opportunity in Higher Education.

Franke, R. (2012). Towards the education nation: Revisiting the impact of financial aid, college experience, and institutional context on baccalaureate degree attainment using a propensity score matching, multilevel modeling approach. (Doctoral dissertation). Retrieved from ProQuest dissertations \& theses full text. (3539086) 
Fenske, R., Porter, J., \& DuBrock, C. (1999). Analyzing student aid packaging to improve low-income and minority student access, retention, and degree completion. Paper presented at the 39th annual forum of the Association for Institutional Research, Seattle, WA.

Foraker, Matthew J. (2012). Does changing majors really affect the time to graduate? The impact of changing majors on student retention, graduation, and time to graduate. Paper presented at the annual meeting of the Association for Institutional Research, New Orleans, LA.

Hahs-Vaughn, D. (2004). The impact of parents' education level on college students: An analysis using the beginning postsecondary students longitudinal study 1990 92/94. Journal of College Student Development, 45(5), 483-500.

Herzog, S. (2005). Measuring determinants of student return vs. dropout/stopout vs. transfer: A first-to-second year analysis of new freshmen. Research in Higher Education, 46(8), 883-928.

Hamrick, F., \& Hossler, D. (1996). Diverse information-gathering methods in the postsecondary decision-making process. The Review of Higher Education, 19(2), 179-198.

Hill, K., Hoffman, D., \& Rex, T. R. (2005). The value of higher education: Individual and societal benefits. Tempe, AZ: L. William Seidman Research Institute, Arizona State University.

Hillman, N.W. (2012). Tuition discounting for revenue management. Research in Higher Education, 53(3), 263-281.

Horn, L.J. (2006). How 4-year college graduation rates vary with selectivity and the size of low-income enrollment (NCES 2007-161). Washington, DC: U.S. Department of Education.

Horn, L.J., \& Nuñez, A. (2000). Mapping the road to college: First generation students' math track, planning strategies, and context of support. Washington, DC: National Center for Education Statistics (NCES).

Horn, L.J. \& Premo, M.D. (1995). Profile of undergraduates in U.S. postsecondary institutions 1992-93: With an essay on undergraduates at risk (NCES 96-237). Washington, DC: National Center for Education Statistics.

Hosch, B.J. (2008, November). Institutional and student characteristics that predict graduation and retention rates. Paper presented at the annual meeting of the North East Association for Institutional Research, Providence, RI. 
Ikenberry, S., \& Hartle, T. (1998). Too little knowledge is a dangerous thing: What the public thinks and knows about paying for college. Washington, D.C.: American Council on Education.

Inkelas, K. K., Daver, Z. E., Vogt, K. E., \& Leonard, J. B. (2007). Living-learning programs and first-generation college students' academic and social transition to college. Research in Higher Education, 48(4), 403-434.

Ishitani, T.T, \& DesJardins, S. (2002). A longitudinal investigation of dropout from college in the United States. Journal of College Student Retention: Research, Theory \& Practice, 4(2), 173-201.

Ishitani, T.T. (2003). A longitudinal approach to assessing attrition behavior among first generation students: Time varying effects of pre-college characteristics. Research in Higher Education, 44 (4), 433-449.

Ishitani, T.T. (2005, June). Studying educational attainment among first-generation students in the United States. Paper presented at the 45th Annual Forum of the Association for Institutional Research; San Diego, CA.

Ishitani, T.T. (2006). Studying attrition and degree completion behavior among firstgeneration college students in the United States. The Journal of Higher Education, 77(5), 861-885.

Kim, D. (2007). The effect of loans on students' degree attainment: Differences by student and institutional characteristics. Harvard Educational Review, 77(1), 6497.

Kim, Y.K., \& Sax, L.J. (2009). Student-faculty interaction in research universities: Differences by student gender, race, social class, and first-generation status. Research in Higher Education, 50(5), 437-459.

Kolb, D. A. (1981). Learning styles and disciplinary differences. In A. W. Chickering and Associates (Eds.), The modern American college (pp. 147-169). San Francisco, CA: Jossey-Bass.

Kroc, R., Howard, R., Hull, P., \& Woodard, D. (1997). Graduation rates: Do students academic program choices make a difference? Paper presented at the Annual Forum of the Association for Institutional Research, Orlando, FL.

Lam, L.P.T. (1999). Assessing financial aid impacts on time-to-degree for nontransfer undergraduate students at a large urban public university. Presented at the 39 th annual forum of the Association for Institutional Research. 
Lee, G. (2010). Determinants of baccalaureate degree completion and time-to-degree for high school graduates in 1992. (Doctoral dissertation). Retrieved from ProQuest dissertations \& theses full text. (3433773)

Leveille, D. (2005). An emerging view on accountability in American higher education. Berkeley, CA: Center for Studies in Higher Education.

Light, A., \& Strayer, W. (2000). Determinants of college completion: School quality or student ability? Journal of Human Resources, 299-332.

Lohfink, M.M., \& Paulsen, M.B. (2005). Comparing the determinants of persistence for first-generation and continuing-generation students. Journal of College Student Development, 46(4), 409-428.

McCormick, A.C. \& Carroll, C.D. (1999). Credit production and progress toward the bachelor's degree: An analysis of postsecondary transcripts for beginning students at 4-year institutions. Washington, DC: U.S. Department of Education.

McDonough, P.M. (1997). Choosing colleges: How social class and schools structure opportunity. Albany, NY: State University of New York Press.

McDonough, P.M., \& Nuñez, A.M. (2007). Bourdieu's sociology of education: Identifying persistent inequality, unmasking domination, and fighting social reproduction. In C.A. Torres \& A. Teodoro (Eds.), Critique and utopia: New developments in the sociology of education in the 21st century (pp. 139-154). Plymouth, UK: Rowman \& Littlefield Publishers.

McMahon, W.W. (2009). Higher learning, greater good: The private and social benefits of higher education. Baltimore, MD: Johns Hopkins University Press.

Moore, C., \& Shulock, N. (2009). Student progress toward degree completion: Lessons from the research literature. Sacramento, CA: Institute for Higher Education Leadership and Policy.

Mortenson, T.G. (March, 1999). Why college? Private correlates of educational attainment. Postsecondary Education Opportunity, 81, 65-88.

Murphy, M. (2000). Predicting graduation: Are test score and high school performance adequate. Paper presented at the annual meeting of the Association for Institutional Research, Cincinnati, $\mathrm{OH}$.

Nora, A., Barlow, E., \& Crisp, G. (2005). Student persistence and degree attainment beyond the first year in college: The need for research. In A. Seidman (Ed.), College student retention: Formula for student success (pp. 129-153). Westport, CT: Praeger Publishers. 
Nora, A., \& Cabrera, A.F. (1996). The role of perceptions of prejudice and discrimination on the adjustment of minority students to college. The Journal of Higher Education, 119-148.

Nora, A., Cabrera, A.F., Hagedorn, L.S., \& Pascarella, E. (1996). Differential impacts of academic and social experiences on college-related outcomes across different ethnic and gender groups at four-year institutions, Research in Higher Education, $37(4), 427-452$.

Nuñez, A.M. (2005). Modeling college transitions of Latino students. (Doctoral dissertation). Retrieved from ProQuest dissertations \& theses full text. (3190475)

Nuñez, A. M., \& Cuccaro-Alamin, S. (1998). First generation students: Undergraduates whose parents never enrolled in postsecondary education (NCES 98-082). Washington, DC: National Center for Education Statistics (NCES).

Olson, L., \& Rosenfeld, R.A. (1984). Parents and the process of gaining access to student financial aid. Journal of Higher Education 55(4), 455-480.

Organization for Economic Cooperation and Development (OECD). (2010). Education at a glance 2010: OECD Indicators. Paris, FR: OECD.

Pascarella, E. T. (1985). Racial differences in factors associated with bachelor's degree completion: A nine-year follow-up. Research in Higher Education, 23(4), 351373.

Pascarella, E.T., Wolniak, G.C. Pierson, C.T., \& Terenzini, P.T. (2003). Experiences and outcomes of first-generation students in community colleges. Journal of College Student Development, 44(3): 420-429.

Pascarella, E. T., Pierson, C. T., Wolniak, G. C., \& Terenzini, P. T. (2004). Firstgeneration college students: Additional evidence on college experiences and outcomes. Journal of Higher Education, 249-284.

Pascarella, E.T., \& Terenzini, P. T. (1991). How college affects students. San Francisco: Jossey-Bass.

Pascarella, E.T. \& Terenzini, P.T. (2005). How college affects students: A third decade of research. San Francisco, CA: Jossey Bass, Inc.

Paulsen, M.B. (2001). The economics of human capital and investment in higher education. In M. B. Paulsen \& J. C. Smart (Eds.), The finance of higher education: Theory, research, policy, and practice (pp. 55-94). New York: Algora Publishing. 
Paulsen, M.B., \& St. John, E.P. (2002). Social class and college costs. The Journal of Higher Education, 73(2), 189-236.

Perna, L.W. (2005). The benefits of higher education: Sex, racial/ethnic, and socioeconomic group differences. The Review of Higher Education, 29(1), 23-52.

Perna, L.W., Fenske, R.H., \& Swail, W.S. (2000). Sponsors of early intervention programs. The ERIC review: Early intervention: Expanding access to higher education, 8(1), 15-18.

Pike, G.R. \& Kuh, G.D. (2005). First and second-generation college students: A comparison of their engagement and intellectual development. The Journal of Higher Education, 76(3), 276-300.

Price, J.L. (1977). The study of turnover. Ames, IA: Iowa State University Press.

Radford, A.W., Berkner, L., Wheeless, S.C., \& Shepherd, B. (2010). Persistence and attainment of 2003-04 beginning postsecondary students: after 6 years. First look (NCES 2011-151). Washington, DC: National Center for Education Statistics (NCES).

Reid, M.J., \& Moore, J.L. (2008). College readiness and academic preparation for postsecondary education: Oral histories of first-generation urban college students. Urban Education, 43(2), 240-261.

Richardson, R.C., \& Skinner, E.F. (1992). Helping first-generation minority students achieve degrees. New Directions for Community Colleges, 80(4), 29-43.

Riehl, R. (1994). The academic preparation, aspirations, and first-year performance of first generation students. College and University, 70(1), 14-19.

Rothwell, J. (2012). Education, job openings, and unemployment in metropolitan America. Washington, DC: Brookings Institution.

Rowley, L.L., \& Hurtado, S. (2002). The non-monetary benefits of an undergraduate education. Ann Arbor, Michigan: Center for the Study of Higher and Postsecondary Education, University of Michigan.

Russell, A. (2011). A guide to major U.S. college completion initiatives. Washington, DC: American Association of State Colleges and Universities.

Sander, L. (2012). Out of uniform: At half a million and counting, veterans cash in on post-9/11 GI Bill. The Chronicle of Higher Education. 
Scott, M., Bailey, T., \& Kienzl, G. (2006). Relative success? Determinants of college graduation rates in public and private colleges in the U.S. Research in Higher Education 47(3), 249-279.

Schultz, A.M. (2012). A comparative study of first generation and continuing-generation college students at a single four-year public university. (Doctoral dissertation). Retrieved from ProQuest dissertations \& theses full text. (3540938)

Snyder, T.D., Tan, A. G., \& Hoffman, C. M. (2003). The condition of education 2003. Washington, DC: National Center for Education Statistics.

Snyder, T.D., Tan, A. G., \& Hoffman, C. M. (2006). Digest of education statistics 2005 (NCES 2006-030). Washington, DC: National Center for Education Statistics.

Somers, P., Woodhouse, S., \& Cofer, J. (2000, November). Persistence of firstgeneration college students. Paper presented at the annual conference of the Association for the Study of Higher Education, Sacramento, CA.

Spady, W.G. (1970). Dropouts from higher education: An interdisciplinary review and synthesis. Interchange, $1(1), 64-85$.

Spady, W.G. (1971). Dropouts from higher education: Toward an empirical model. Interchange, 2(3), 38-62.

Stanton-Salazar, R. D. (1997). A social capital framework for understanding the socialization of racial minority children and youths. Harvard Educational Review, $67(1), 1-41$.

Swail, W.S. (2009). Graduating at-risk students: A cross-sector analysis. Washington, DC: Imagine America Foundation.

Tabachnick, B.G. \& Fidell, L.S. (2001). Using multivariate statistics $\left(4^{\text {th }}\right.$ ed.). Needham Heights, MA: Allyn \& Bacon.

Terenzini, P., Rendon, L., Upcraft, M., Millar, J., Allison, K., Gregg, P., \& Jalomo, R. (1994). The transition to college: Diverse students, diverse stories. Research in Higher Education, 30, 301-315.

Terenzini, P.T., Springer, L. P. M. Yaeger, P.M. Pascarella, E.T. \& Nora, A. (1996). First generation college students: Characteristics, experiences, and cognitive development. Research in Higher Education, 37(1), 1-22.

Thomas, S. L., \& Heck, R. H. (2001). Analysis of large-scale secondary data in higher education research: Potential perils associated with complex sampling designs. Research in Higher Education, 42(5), 517-540. 
Tinto, V. (1975). Dropout from higher education: A theoretical synthesis of recent research. Review of Educational Research, 45(1), 89-125.

Tinto, V. (1993). Leaving college (2nd ed.). Chicago: University of Chicago Press.

Titus, M.A. (2006). Understanding college degree completion of students with low socioeconomic status: The influence of the institutional financial context. Research in Higher Education, 47(4), 371-398.

Torres, V., Reiser, A., LePeau, L., Davis, L., \& Ruder, J. (2006). A model of firstgeneration Latino/a college students' approach to seeking academic information. NACADA Journal, 26(2), 65-70.

Tym, C., McMillion, R., Barone, S. \& Webster, J. (2004). First generation college students: A literature review. Round Rock, TX: Research and Analytical Services, Texas Guaranteed Student Loan Corporation.

U.S. Department of Education. (2011). Meeting the nation's 2020 goal: State targets for increasing the number and percentage of college graduates with degrees.

Washington, DC: U.S. Department of Education.

Vargas, J.H. (2004). College knowledge: Addressing information barriers to college. Boston, MA: The Education Resources Institute.

Warburton, E.C., Bugarin, R. \& Nuñez, A. (2001). Bridging the gap: Academic preparation and postsecondary success of first generation students (NCES 2001153). Washington, DC: National Center for Education Statistics (NCES).

Wine, J., Janson, N., \& Wheeless, S. (2011). 2004/09 beginning postsecondary students longitudinal study (BPS:04/09) full-scale methodology report (NCES 2012-246). Washington DC: National Center for Education Statistics.

Wirt, J., Choy, S., Gerald, D., Provasnik, S., Rooney, P. Watanabe, S., Tobin, R. (2002). The condition of education 2002 (NCES 2002-025). Washington, DC: National Center for Education Statistics (NCES).

York-Anderson, D.C., \& Bowman, S.L. (1991). Assessing the college knowledge of firstgeneration and second-generation college students. Journal of College Student Development, 32(2), 116-122.

Zucker, B. \& Dawson, R. (2001). Credits and attainment: Returns to postsecondary education ten years after high school (NCES 2001-168). Washington, DC: National Center for Education Statistics (NCES). 